Prepared in cooperation with the Bureau of Reclamation

\title{
Water Budgets of the Walker River Basin and Walker Lake, California and Nevada
}

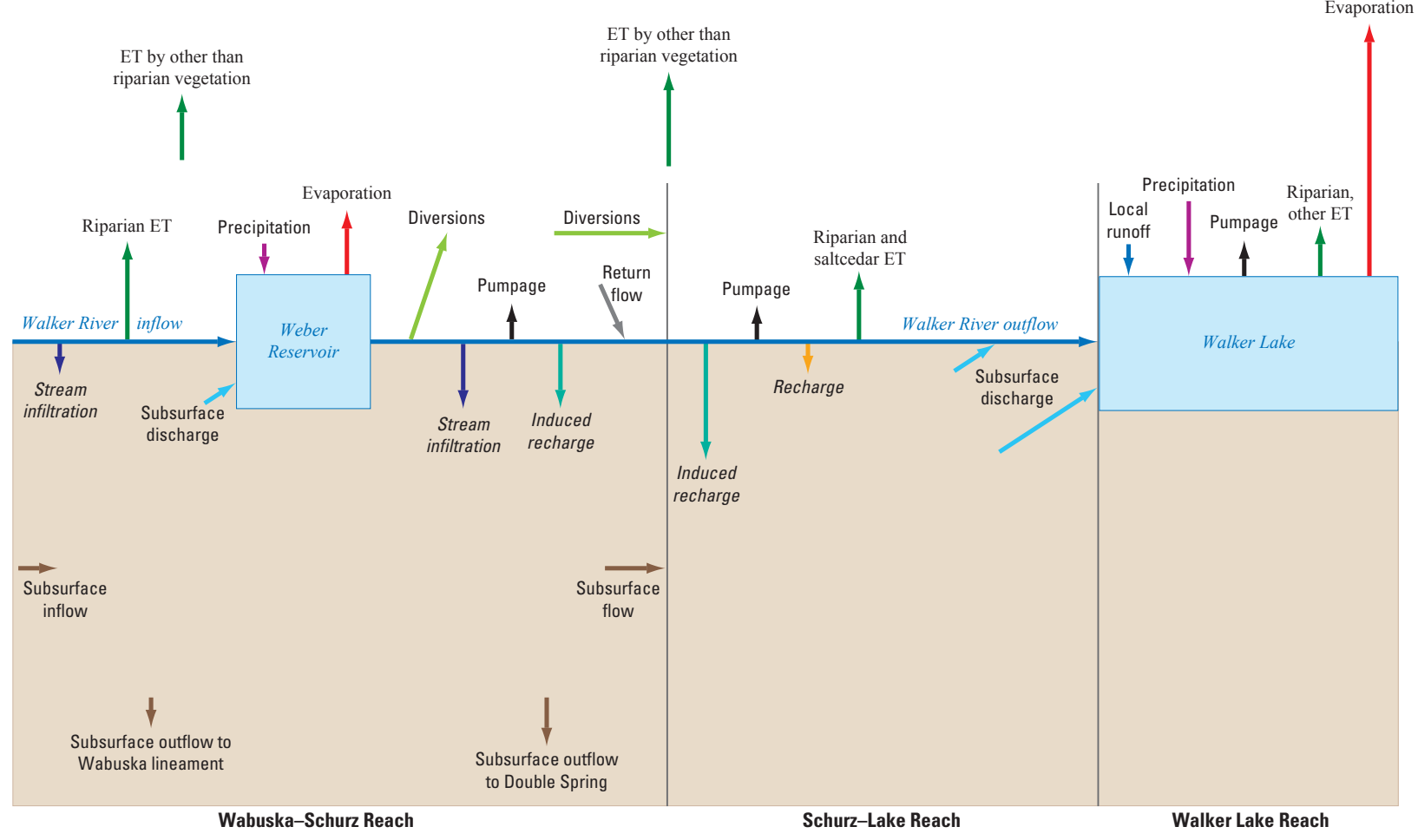

Scientific Investigations Report 2009-5157 
Cover: Photographs from left to right:

Left: Alfalfa field in Antelope Valley, Nevada and California, with the Sweetwater Range in the background, May 31, 2006.

Middle: Sacks filled with onions during the 2006 autumn harvest, Pete Hendrichs Road,

Mason Valley, Nevada, October 13, 2006.

Right: View from Walker Lake looking southwest at Mount Grant, Nevada, February 28, 2005. (Photographs taken by Thomas J. Lopes, U.S. Geological Survey.)

Diagram: Water budget components for the lower Walker River basin, Nevada. The length of the arrow indicates the relative amount of flow. The Walker Lake reach includes surrounding riparian and phreatophytic vegetation and the town of Walker Lake. 


\section{Water Budgets of the Walker River Basin and Walker Lake, California and Nevada}

By Thomas J. Lopes and Kip K. Allander

Prepared in cooperation with the Bureau of Reclamation

Scientific Investigations Report 2009-5157 


\title{
U.S. Department of the Interior \\ KEN SALAZAR, Secretary \\ U.S. Geological Survey \\ Suzette M. Kimball, Acting Director
}

\section{U.S. Geological Survey, Reston, Virginia: 2009}

\author{
For more information on the USGS - the Federal source for science about the Earth, its natural and living resources, \\ natural hazards, and the environment, visit http://www.usgs.gov or call 1-888-ASK-USGS \\ For an overview of USGS information products, including maps, imagery, and publications, \\ visit http://www.usgs.gov/pubprod \\ To order this and other USGS information products, visit http://store.usgs.gov
}

\begin{abstract}
Any use of trade, product, or firm names is for descriptive purposes only and does not imply endorsement by the U.S. Government.

Although this report is in the public domain, permission must be secured from the individual copyright owners to reproduce any copyrighted materials contained within this report.
\end{abstract}

Suggested citation:

Lopes, T.J., and Allander, K.K., 2009, Water budgets of the Walker River basin and Walker Lake, California and Nevada: U.S. Geological Survey Scientific Investigations Report 2009-5157, 44 p. 


\section{Contents}

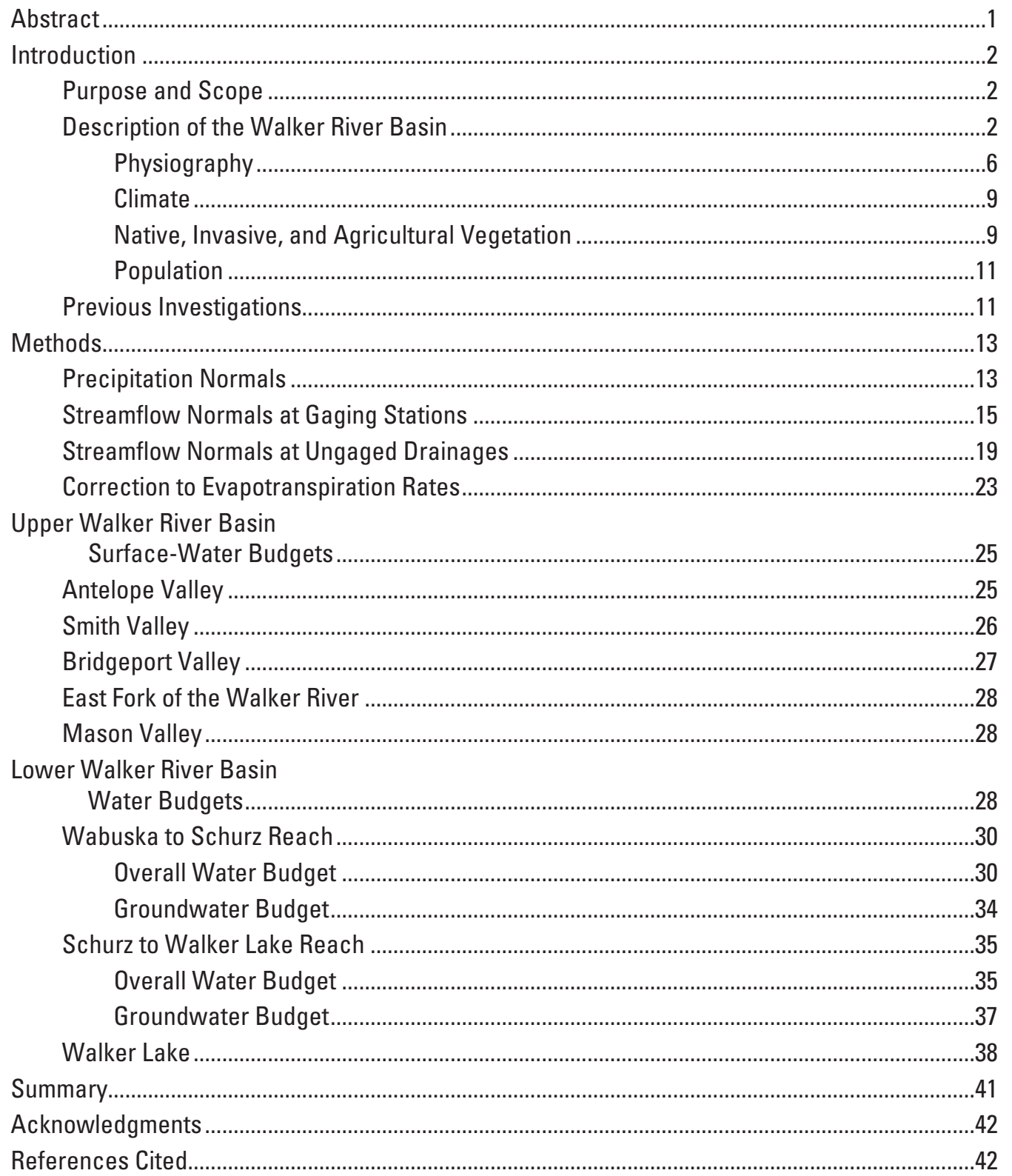




\section{Figures}

Figure 1. Map showing locations of selected features in the Walker River basin, California and Nevada

Figure 2. Photograph showing view looking north from the southwestern end of Walker Lake, Nevada

Figure 3. Graph showing lake-surface altitude and dissolved-solids concentrations of Walker Lake, Nevada, from 1882 through September 30, 2008

Figure 4. Photograph showing vew looking upstream and southwest at the streamflow-gaging station Walker River near Wabuska, Nevada.

Figure 5. Photograph showing Bridgeport Valley, California, looking south from Highway 395 towards the Twin Lakes area and 12,000-foot peaks of the Sierra Nevada.

Figure 6. Photograph showing riparian vegetation along the Walker River between the Wabuska gage and Weber Reservoir, Nevada

Figure 7. Photograph showing vew looking south at Walker Lake from the mouth of the Walker River, Nevada

Figure 8. Photograph showing view from northeastern Smith Valley looking southwest towards Artesia Lake and the Pine Nut Range, Nevada

Figure 9. Photograph showing view from Walker Lake looking southwest at Mount Grant, Nevada

Figure 10. Photograph showing view from Walker Lake looking east at a thunderstorm over the Gillis Range, Nevada

Figure 11. Map showing distribution of 88,600 acres of irrigated land in the Walker River basin, California and Nevada, during the 2000 growing season

Figure 12. Map showing distribution of precipitation in the Walker River basin, California and Nevada

Figure 13. Map showing locations of stream gages in the Walker River basin, California and Nevada

Figure 14. Map and table showing locations of drainages in California and Nevada that were used to estimate runoff from ungaged drainages in the Walker River basin

Figure 15. Graphs showing predicted compared to observed 1971-2000 streamflow normals and constrained regressions compared to observed streamflow normals

Figure 16. Schematic diagram showing water budget components for the lower Walker River basin, Nevada

Figure 17. Map showing selected areas of the lower Walker River basin, Nevada, where net evapotranspiration was quantified

Figure 18. Graphs showing annual stream discharge at Schurz, Nevada, compared to annual discharge at the Wabuska gage prior to and after construction of Weber Reservoir in 1934 and subset of data plotted on log scale to show differences at low discharge.

Figure 19. Graph showing discharge at streamflow gaging stations Walker River near Wabuska, Nevada, and Walker River at Lateral 2-A Siphon near Schurz, Nevada

Figure 20. Graph showing dissolved-solids concentrations versus lake altitude, Walker Lake, Nevada 


\section{Tables}

Table 1. Mean annual precipitation volumes for hydrographic areas in the Walker

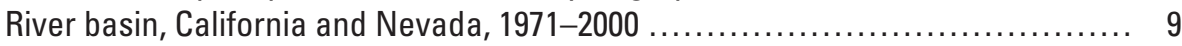

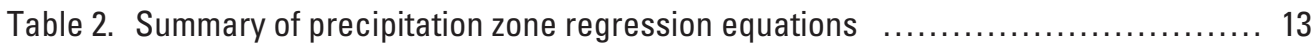

Table 3. Streamflow normals at selected gaging stations with 30 complete years of data, Walker and Carson River basins and Toiyabe Range, California and

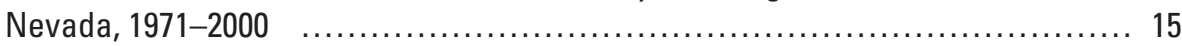

Table 4. Streamflow data from drainages in the Wassuk Range, Nevada ................. 17

Table 5. Estimated streamflow normals at selected gaging stations with less than 30 complete years of data, California and Nevada, 1971-2000 .................... 18

Table 6. Estimated streamflow normals from ungaged drainages in the Walker River basin, California and Nevada, 1971-2000 ............................... 24

Table 7. Estimated evaporation from Walker Lake, Nevada, during the 1987-94 drought ... 25

Table 8. Summary of surface-water inflows in the upper Walker River basin,

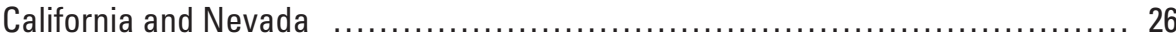

Table 9. Summary of surface-water budgets for the upper Walker River basin,

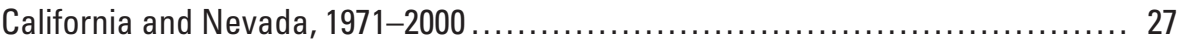

Table 10. Overall water budget for the Wabuska-Schurz reach, lower Walker River

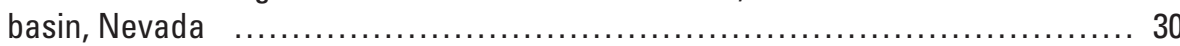

Table 11. Estimates of subsurface flow through Walker and Parker Gaps, lower Walker River basin, Nevada ........................................ 32

Table 12. Net evapotranspiration from selected areas of the lower Walker River basin,

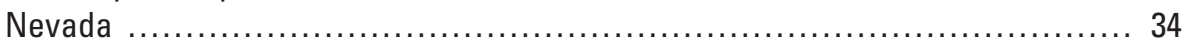

Table 13. Ground-water budget for the Wabuska-Schurz reach, lower Walker River

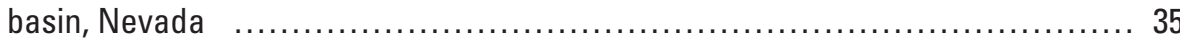

Table 14. Overall water budget for the Schurz-Lake reach, lower Walker River basin,

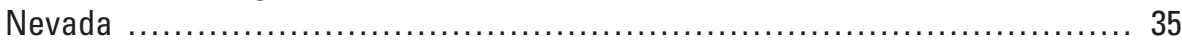

Table 15. Overall water budget from Wabuska to Walker Lake, lower Walker River basin, Nevada

Table 16. Ground-water budget for the Schurz-Lake reach, lower Walker River basin, Nevada.

Table 17. Overall water budget for Walker Lake, Nevada............................ 38

Table 18. Water budget to maintain lake-surface altitudes between 3,952 and 3,986 feet at Walker Lake, Nevada 


\section{Conversion Factors and Datums}

Conversion Factors

\begin{tabular}{|c|c|c|}
\hline Multiply & By & To obtain \\
\hline \multicolumn{3}{|c|}{ Length } \\
\hline inch (in.) & 2.54 & centimeter $(\mathrm{cm})$ \\
\hline foot $(\mathrm{ft})$ & 0.3048 & meter $(\mathrm{m})$ \\
\hline mile (mi) & 1.609 & kilometer $(\mathrm{km})$ \\
\hline \multicolumn{3}{|c|}{ Area } \\
\hline acre & 0.004047 & square kilometer $\left(\mathrm{km}^{2}\right)$ \\
\hline square mile $\left(\mathrm{mi}^{2}\right)$ & 2.590 & square kilometer $\left(\mathrm{km}^{2}\right)$ \\
\hline \multicolumn{3}{|c|}{ Volume } \\
\hline acre-foot (acre-ft) & 1,233 & cubic meter $\left(\mathrm{m}^{3}\right)$ \\
\hline \multicolumn{3}{|c|}{ Flow rate } \\
\hline foot per year (ft/yr) & 0.3048 & meter per year $(\mathrm{m} / \mathrm{yr})$ \\
\hline inch per year (in/yr) & 25.4 & millimeter per year $(\mathrm{mm} / \mathrm{yr})$ \\
\hline acre-foot per year (acre-ft/yr) & 1,233 & cubic meter per year $\left(\mathrm{m}^{3} / \mathrm{yr}\right)$ \\
\hline cubic foot per second $\left(\mathrm{ft}^{3} / \mathrm{s}\right)$ & 0.02832 & cubic meter per second $\left(\mathrm{m}^{3} / \mathrm{s}\right)$ \\
\hline mile per hour $(\mathrm{mi} / \mathrm{h})$ & 1.609 & kilometer per hour $(\mathrm{km} / \mathrm{h})$ \\
\hline \multicolumn{3}{|c|}{ Hydraulic conductivity } \\
\hline foot per day (ft/d) & 0.3048 & meter per day $(\mathrm{m} / \mathrm{d})$ \\
\hline \multicolumn{3}{|c|}{ Transmissivity* } \\
\hline foot squared per day $\left(\mathrm{ft}^{2} / \mathrm{d}\right)$ & 0.09290 & meter squared per day $\left(\mathrm{m}^{2} / \mathrm{d}\right)$ \\
\hline
\end{tabular}

Temperature in degrees Fahrenheit $\left({ }^{\circ} \mathrm{F}\right)$ may be converted to degrees Celsius $\left({ }^{\circ} \mathrm{C}\right)$ as follows:

${ }^{\circ} \mathrm{C}=\left({ }^{\circ} \mathrm{F}-32\right) / 1.8$

*Transmissivity: The standard unit for transmissivity is cubic foot per day per square foot times foot of aquifer thickness [(ft $\left.\left.\mathrm{t}^{3} / \mathrm{d}\right) / \mathrm{ft}^{2}\right] \mathrm{ft}$. In this report, the mathematically reduced form, foot squared per day $\left(\mathrm{ft}^{2} / \mathrm{d}\right)$, is used for convenience.

Concentrations of chemical constituents in water are given either in milligrams per liter (mg/L) or micrograms per liter $(\mu \mathrm{g} / \mathrm{L})$.

Datums

Vertical coordinate information is referenced to National Geodetic Vertical Datum of 1929 (NGVD 29).

Horizontal coordinate information is referenced to North American Datum of 1983 (NAD 83).

Altitude, as used in this report, refers to distance above the vertical datum. 


\title{
Water Budgets of the Walker River Basin and Walker Lake, California and Nevada
}

\author{
By Thomas J. Lopes and Kip K. Allander
}

\section{Abstract}

The Walker River is the main source of inflow to Walker Lake, a closed-basin lake in west-central Nevada. The only outflow from Walker Lake is evaporation from the lake surface. Between 1882 and 2008, upstream agricultural diversions resulted in a lake-level decline of more than 150 feet and storage loss of 7,400,000 acre-feet. Evaporative concentration increased dissolved solids from 2,500 to 17,000 milligrams per liter. The increase in salinity threatens the survival of the Lahontan cutthroat trout, a native species listed as threatened under the Endangered Species Act. This report describes streamflow in the Walker River basin and an updated water budget of Walker Lake with emphasis on the lower Walker River basin downstream from Wabuska, Nevada. Water budgets are based on average annual flows for a 30-year period (1971-2000).

Total surface-water inflow to the upper Walker River basin upstream from Wabuska was estimated to be 387,000 acre-feet per year (acre-ft/yr). About 223,000 acre-ft/yr (58 percent) is from the West Fork of the Walker River; 145,000 acre-ft/yr (37 percent) is from the East Fork of the Walker River; 17,000 acre-ft/yr (4 percent) is from the Sweetwater Range; and 2,000 acre-ft/yr (less than 1 percent) is from the Bodie Mountains, Pine Grove Hills, and western Wassuk Range. Outflow from the upper Walker River basin is 138,000 acre-ft/yr at Wabuska. About 249,000 acre-ft/yr (64 percent) of inflow is diverted for irrigation, transpired by riparian vegetation, evaporates from lakes and reservoirs, and recharges alluvial aquifers.

Stream losses in Antelope, Smith, and Bridgeport Valleys are due to evaporation from reservoirs and agricultural diversions with negligible stream infiltration or riparian evapotranspiration. Diversion rates in Antelope and Smith Valleys were estimated to be 3.0 feet per year (ft/yr) in each valley. Irrigated fields receive an additional $0.8 \mathrm{ft}$ of precipitation, groundwater pumpage, or both for a total applied-water rate of $3.8 \mathrm{ft} / \mathrm{yr}$. The average corrected total evapotranspiration rate for alfalfa is $3.2 \mathrm{ft} / \mathrm{yr}$ so about $0.6 \mathrm{ft} / \mathrm{yr}$ (15 percent) flushes salts from the soil. The diversion rate in Bridgeport Valley was estimated to be $1.1 \mathrm{ft} / \mathrm{yr}$ and precipitation is $1.3 \mathrm{ft} / \mathrm{yr}$. The total applied-water rate of $2.4 \mathrm{ft} / \mathrm{yr}$ is used to irrigate pasture grass.
The total applied water rate in the East Fork of the Walker River and Mason Valley was estimated to be $4.8 \mathrm{ft} / \mathrm{yr}$ in each valley. The higher rate likely is due to appreciable infiltration, riparian evapotranspiration, or both. Assuming a diversion rate of $3.0 \mathrm{ft} / \mathrm{yr}$, stream loss due to infiltration and riparian evapotranspiration is about 3,000 acre-ft/yr along the East Fork of the Walker River and 14,000 acre-ft/yr in Mason Valley.

In the lower Walker River basin, overall and groundwater budgets were calculated for Wabuska to Schurz, Nev., and Schurz to Walker Lake. An overall water budget was calculated for the combined reaches. Imbalances in the water budgets range from 1 to 7 percent, which are insignificant statistically, so the water budgets balance. Total inflow to the Wabuska-Walker Lake reach from the river and others sources is 140,000 acre-ft/yr. Stream and subsurface discharge into the northern end of Walker Lake totals 110,000 acre-ft/yr. About 30,000 acre-ft/yr is lost on the Walker River Indian Reservation from agricultural evapotranspiration, evapotranspiration by native and invasive vegetation, domestic pumpage, and subsurface outflow from the basin through Double Spring and the Wabuska lineament.

Alfalfa fields in the upper Walker River basin are lush and have an average corrected total evapotranspiration rate of $3.2 \mathrm{ft} / \mathrm{yr}$. Alfalfa fields on the Walker River Indian Reservation are not as lush and have a total corrected evapotranspiration rate of 1.6-2.1 ft/yr, which partly could be due to alkaline soils that were submerged by Pleistocene Lake Lahontan. The total applied-water rate is $7.0 \mathrm{ft} / \mathrm{yr}$, almost twice the rate for alfalfa in the upper Walker River basin. Most of this excess water becomes induced recharge, which is irrigation water that infiltrates to the water table.

Surface and subsurface inflow to Walker Lake total $130,000 \mathrm{acre}-\mathrm{ft} / \mathrm{yr}$. Virtually all outflow is evaporation from the lake and totals 162,000 acre-ft/yr at the 1971-2000 average lake altitude of 3,959.3 feet. The difference between inflow and outflow is $-32,000$ acre- $\mathrm{ft} / \mathrm{yr}$. Storage change estimated directly is $-29,000$ acre-ft/yr for an imbalance of 3,000 acre-ft/yr (2 percent). This imbalance is insignificant statistically so the water budget balances.

Water budgets were calculated to provide managers a range in supplemental inflows needed to maintain dissolvedsolids concentrations at 8,000,10,000, and 12,000 milligrams per liter (mg/L). From about 700,000 to 2,000,000 acre-ft 
are needed to dilute the lake to these concentrations from the current (2008) concentration of 17,000 mg/L. From 26,000 to 53,000 acre-ft/yr of supplemental inflow is needed to maintain concentrations of 8,000 to $12,000 \mathrm{mg} / \mathrm{L}$. Years of supplemental inflow, above average inflow, or both, will be needed to raise the lake-surface altitude and dilute salts.

\section{Introduction}

The Walker River basin is a topographically closed basin in east-central California and west-central Nevada (fig. 1). All surface water drains toward Walker Lake, the lowest point in the basin and the terminus of the Walker River (fig. 2). The Walker River is the main source of inflow, but small tributaries from adjacent mountains and groundwater also discharge into Walker Lake (Everett and Rush, 1967; Schaefer, 1980; Lopes and Allander, 2009). The only outflow from Walker Lake is evaporation from the lake surface. The Walker River has been diverted for irrigation in upstream valleys since 1860, which has reduced flow into Walker Lake (Russell, 1885; Horton, 1995). Between 1882 and 2008, agricultural diversions resulted in a lake-level decline of more than $150 \mathrm{ft}$ and evaporative concentration increased dissolved solids from 2,500 to $17,000 \mathrm{mg} / \mathrm{L}$ (fig. 3). The increase in salinity threatens the survival of the Lahontan cutthroat trout, a species listed as threatened under the Endangered Species Act.

Section 2507 of Public Law 107-171 (2002 Farm Bill) provided $\$ 200$ million to be used by the Secretary of Interior, acting through the Commissioner of Reclamation, to provide water to at-risk natural desert terminal lakes. This bill was later amended under Public Law 108-7, section 207 to include this language, "Restoration of fish, wildlife, and associated habitats in watersheds of certain lakes." The amendment specified that only Pyramid, Summit, and Walker Lakes in Nevada were to be considered under Section 2507, PL107-171.

In response to the 2002 Farm Bill, the U.S. Geological Survey (USGS), in cooperation with the Bureau of Reclamation, began a study to refine the water budget for Walker Lake and to develop the capability to predict how changes in upstream water management will affect flows in the lower Walker River basin. This is the final report from the study. Lopes (2005) described the objectives and tasks of the study; Lopes and Smith (2007) described the bathymetry of Walker Lake, Lopes and Medina (2007) estimated precipitation in west-central Nevada including the Walker River basin; Allander and others (2009) quantified evapotranspiration (ET) from Walker Lake and agricultural, native, and invasive vegetation; and Lopes and Allander (2009) described the hydrologic setting, groundwater flow directions, and a conceptual model of groundwater/surfacewater interactions from Smith Valley to Walker Lake.

\section{Purpose and Scope}

This report describes streamflow in the Walker River basin and presents an updated water budget of Walker Lake. The report emphasizes the lower Walker River basin, which is the area downstream from the streamflow-gaging station Walker River near Wabuska, Nev. (Wabuska gage, 10301500; figs. 1, 4). Surface-water budgets for the upper Walker River basin upstream from the Wabuska gage also are presented. Data for this study were collected from 2004 through 2008 and used with existing data to calculate average annual flows.

Water budgets are based on average annual flows for a 30-yr period (1971-2000). Using average flows may give the impression of steady-state conditions but, as shown in figure 3 , the lake level continues to decline and flows into and out from the lake vary annually. However, it was beyond the scope of this study to account for the transient nature of the basin hydrology.

\section{Description of the Walker River Basin}

The following is an abbreviated description of the Walker River basin from Lopes and Allander (2009). The Walker River basin is about 3,950 $\mathrm{mi}^{2}$ and straddles the CaliforniaNevada border (fig. 1). About 23 percent $\left(920 \mathrm{mi}^{2}\right)$ of the basin is in California. Most streamflow in the basin originates as snowmelt in the Sierra Nevada, which reach an altitude of more than 12,000 ft (fig. 5). Snowmelt from the Sierra Nevada and other ranges flows down the East and West Forks of the Walker River, which merge in southern Mason Valley, Nev. Outflow from Mason Valley and inflow to the lower Walker River basin is measured at the Wabuska gage in northern Mason Valley.

Bridgeport Reservoir on the East Fork of the Walker River and Topaz Lake on the West Fork of the Walker River are used for fishing and recreation, and have a combined useable storage capacity of about 103,000 acre-ft. Stored water is used to irrigate mostly alfalfa in Smith and Mason Valleys and to sustain a minimum streamflow into the Walker River Indian Reservation (Reservation). Streams also are diverted upstream from Bridgeport Reservoir to irrigate pasture grass (fig. 5) and upstream from Topaz Lake to irrigate mostly alfalfa fields in Antelope Valley.

Russell (1885) described lush cottonwood groves, willow stands, and meadows along the banks of the Walker River from its mouth at Walker Lake to many miles upstream. Since 1885, most cottonwood between the Wabuska gage and Weber Reservoir were cut down. Except for the cutting of cottonwood, the Walker River between the Wabuska gage and Weber Reservoir is relatively unaffected by human activities (fig. 6). Willows grow along the river, beaver built dams from willow branches, and grass meadows cover the inside banks of stream meanders. 


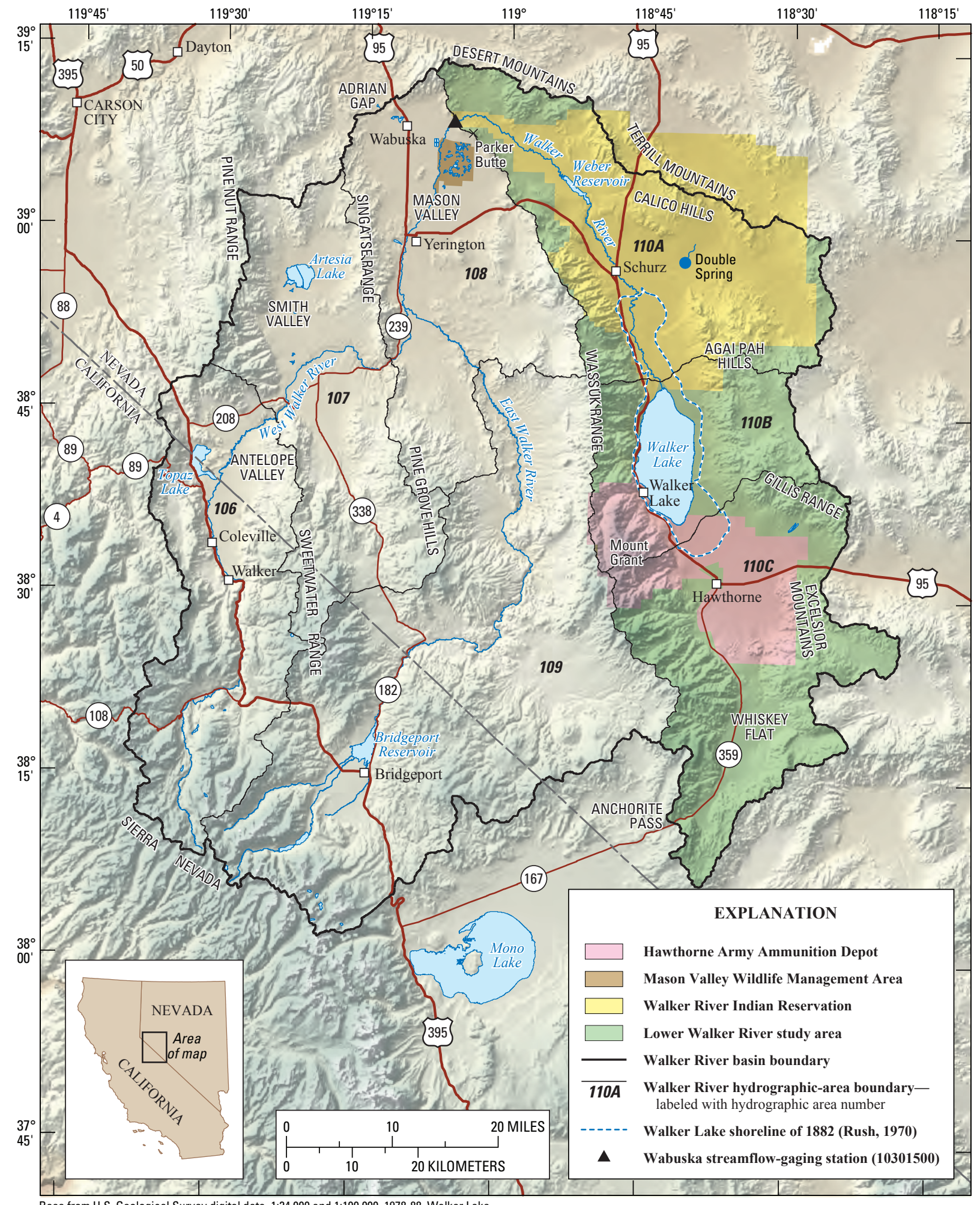

Base from U.S. Geological Survey digital data, 1:24,000 and 1:100,000, 1978-88. Walker Lake

average lake altitude of $3937.5 \mathrm{ft}$ for November 2006; Projection: Universal Transverse

Shuttle Radar Topography Mission digital data, 2000.

Figure 1. Locations of selected features in the Walker River basin, California and Nevada. 


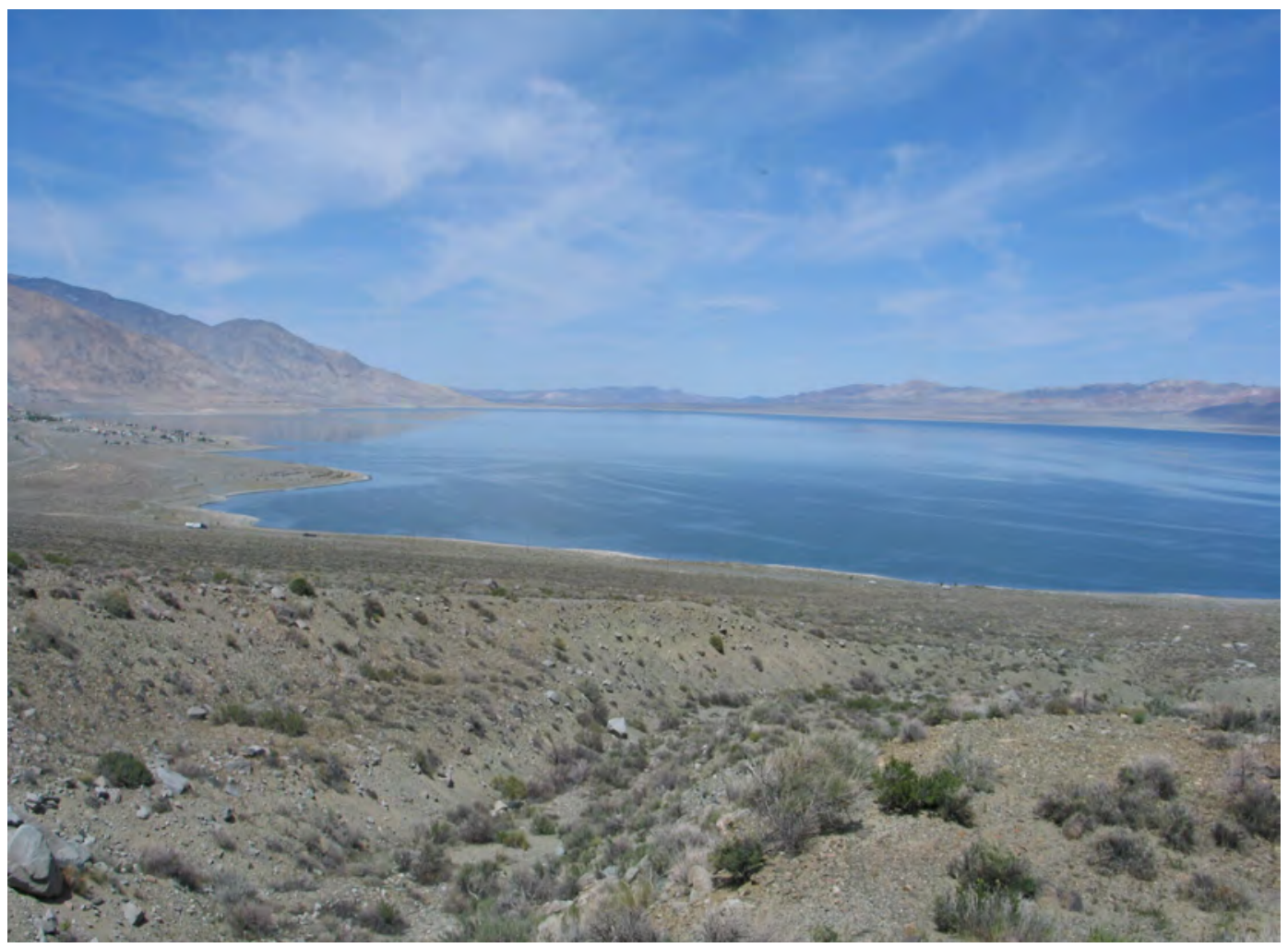

Figure 2. View looking north from the southwestern end of Walker Lake, Nevada. The town of Walker Lake is in the left center of the photo. (Photograph taken by Thomas J. Lopes, April 23, 2004.)

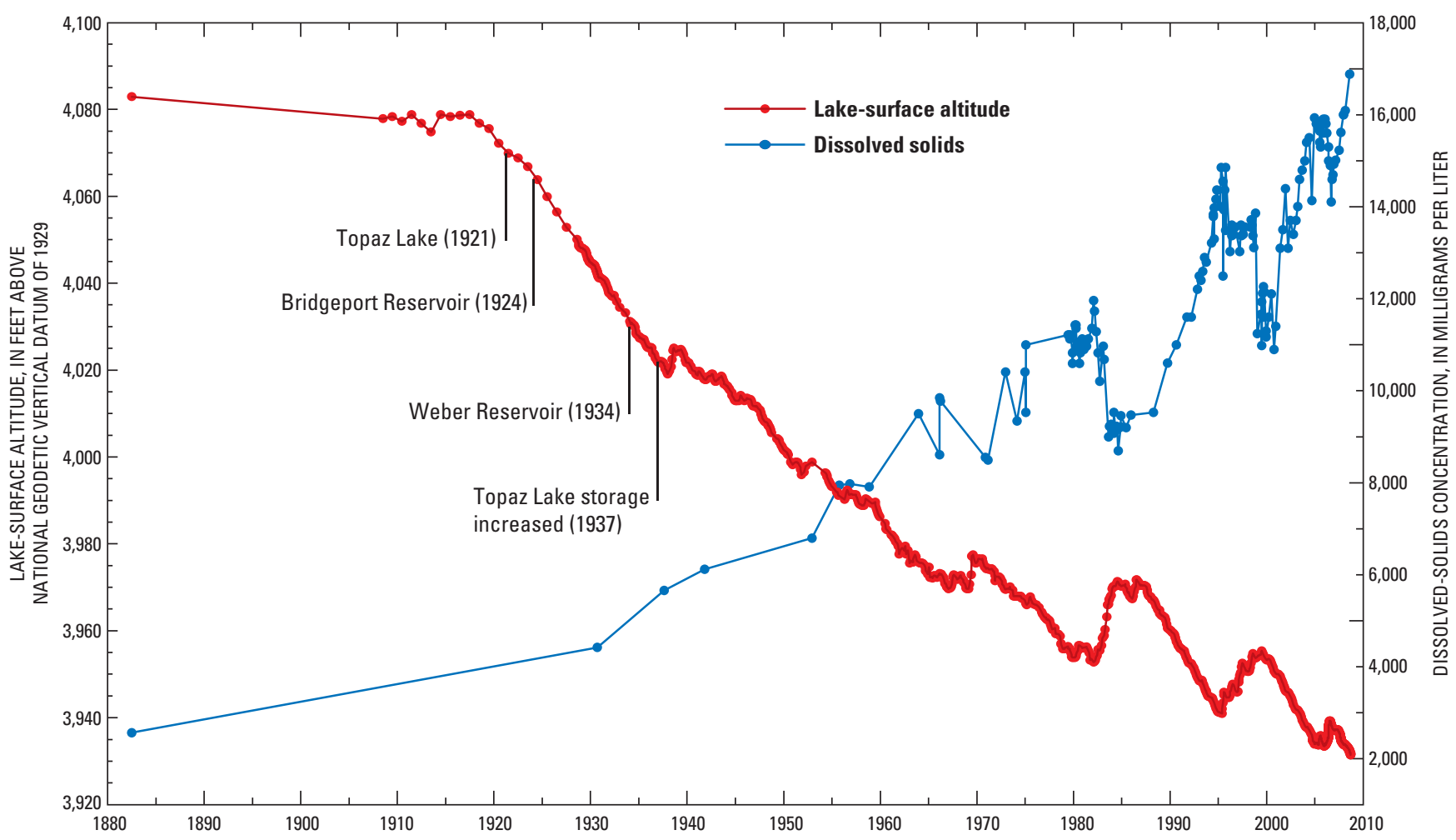

Figure 3. Lake-surface altitude and dissolved-solids concentrations of Walker Lake, Nevada, from 1882 through September 30, 2008. 


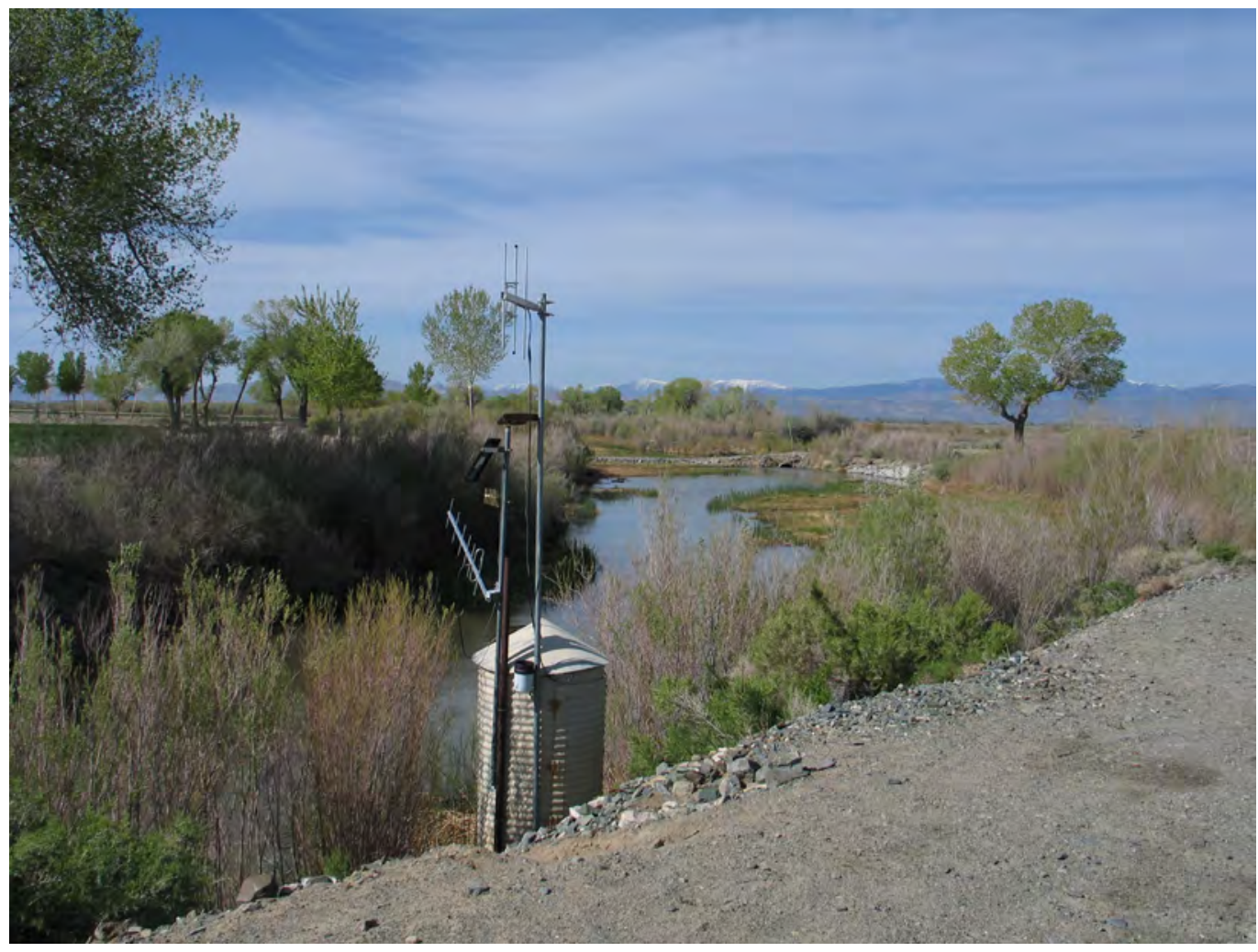

Figure 4. Vew looking upstream and southwest at the streamflow-gaging station Walker River near Wabuska, Nevada. (USGS station number 10301500). (Photograph taken by Thomas J. Lopes, April 23, 2004.)

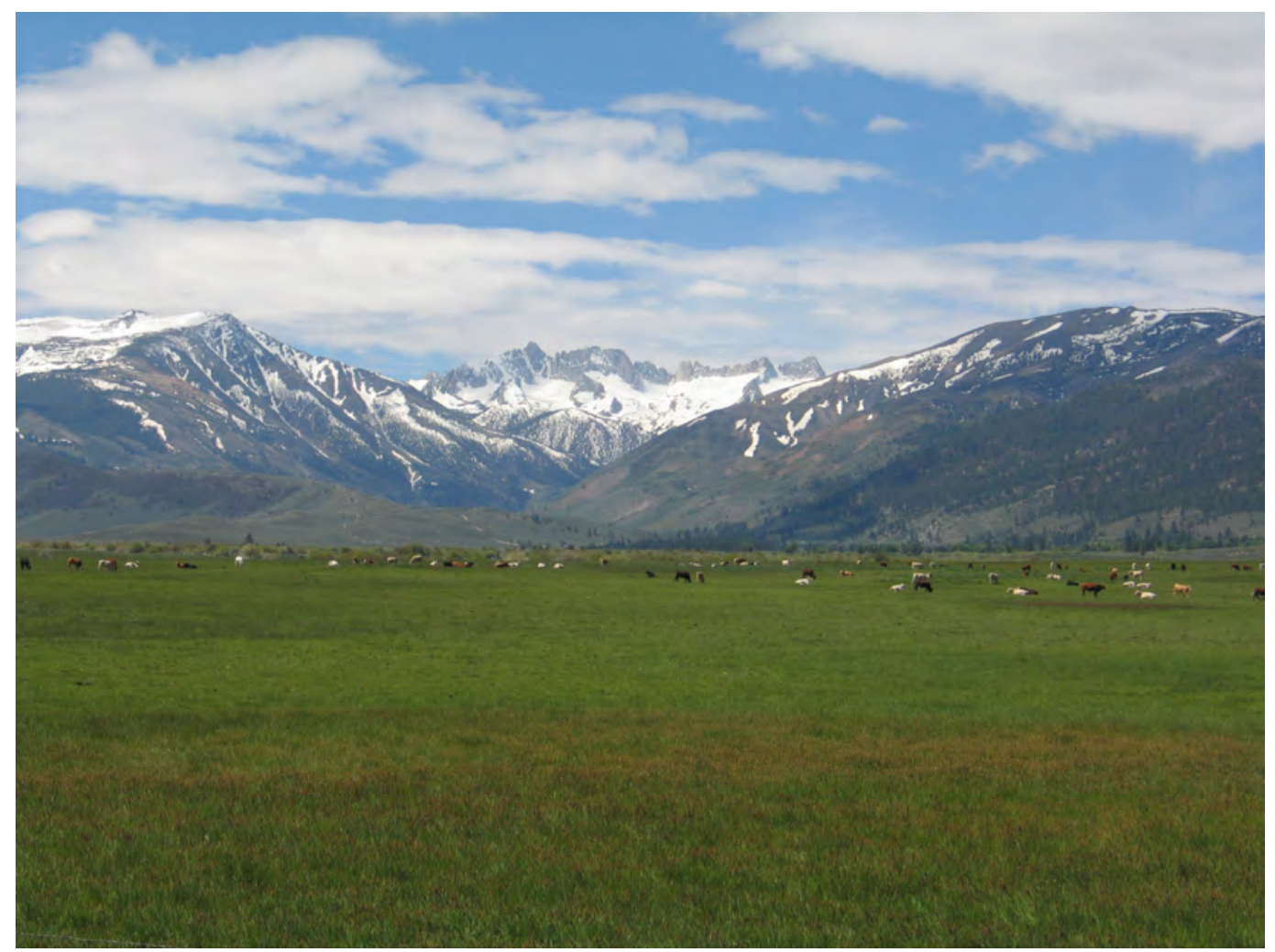

Figure 5. Bridgeport Valley, California, looking south from Highway 395 towards the Twin Lakes area and 12,000-foot peaks of the Sierra Nevada. Pasture grass in the foreground is irrigated by ditches that divert snowmelt. (Photograph taken by Thomas J. Lopes, June 3, 2008.) 


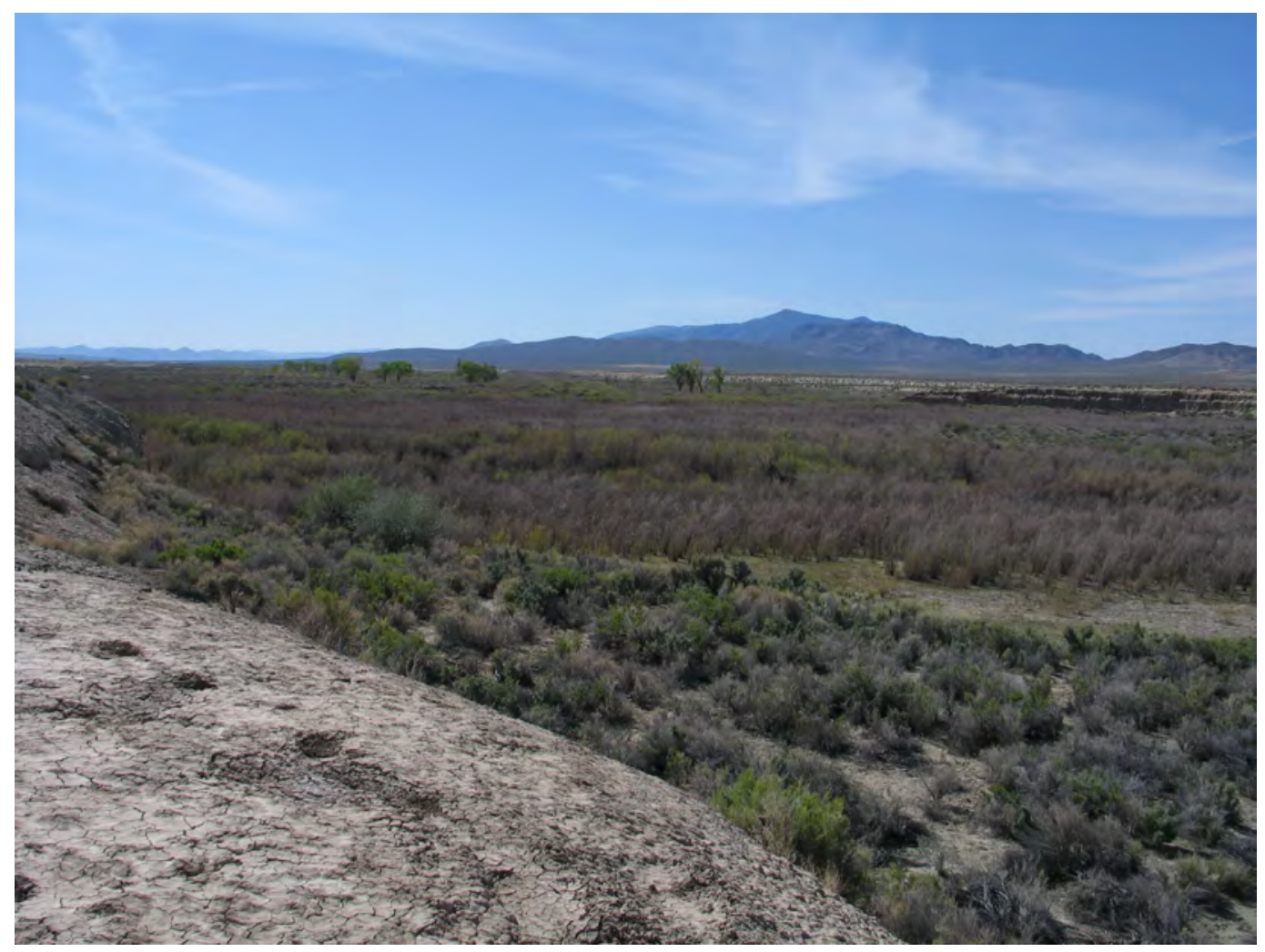

Figure 6. Riparian vegetation along the Walker River between the Wabuska gage and Weber Reservoir, Nevada. Bare soil in the foreground is lake sediment deposited during the Pleistocene. View looking south towards the Wassuk Range. (Photograph taken by Thomas J. Lopes, April 23, 2004.)

Weber Reservoir is used for fishing, recreation, and storing irrigation water on the Reservation. Downstream from Weber Reservoir, cottonwood grows along the Walker River to about 2 mi downstream from Schurz, Nev., near the 1882 shoreline where cottonwood were first observed by Russell (1885). The Walker River continues downstream through stands of saltcedar, an invasive shrub also known as tamarisk. Saltcedar grows in alkaline lake clays that became exposed as Walker Lake receded. The river then discharges into the northern end of Walker Lake (fig. 7).

\section{Physiography}

The Walker River basin is in the Great Basin subdivision of the Basin and Range Physiographic Province. The Basin and Range is characterized by north-south trending mountain ranges separated by valleys. The Great Basin is the part of the Basin and Range that has no surface-water drainage to the ocean, is centered in Nevada, and includes parts of California, Idaho, Oregon, and Utah.

Many watersheds in the Great Basin are comprised of multiple valleys that are interconnected by streams and subsurface flow (Anning and Konieczki, 2005). Where hydraulically connected, rivers and groundwater flow between valleys, and the valley at the lowest altitude is the terminus for the watershed. Most watersheds in the Great Basin do not have perennial rivers so the terminus is a playa consisting of barren mud and salt flats with intermittent water, such as Artesia Lake in northern Smith Valley (fig. 8). Terminuses that have perennial water include Mono Lake, Calif., and the Great Salt Lake, Utah. Owens Lake, Calif., was a perennial terminal lake until the early 1900s when diversions turned the lake into a $100 \mathrm{mi}^{2}$ playa. Walker, Pyramid, and Summit Lakes are three of the few terminal lakes in the United States that support a fishery.

Walker Lake fills a depression within the Walker Lane, a broad zone of mostly north-northwest trending faults that extends from near Las Vegas, Nev., to Honey Lake Valley, Calif. (Bonham, 1969; Stewart, 1988). Walker Lake is bounded on the west by the Wassuk Range and on the east by the Gillis Range. The Wassuk Range rises abruptly from the lake by more than 7,000 $\mathrm{ft}$ and has a maximum altitude of $11,239 \mathrm{ft}$ at Mount Grant (fig. 9). The Gillis Range is not as steep and has a maximum altitude of $7,887 \mathrm{ft}$ (fig. 10). The lowest altitude is $3,849 \mathrm{ft}$ at the deepest part of Walker Lake (Lopes and Smith, 2007). 


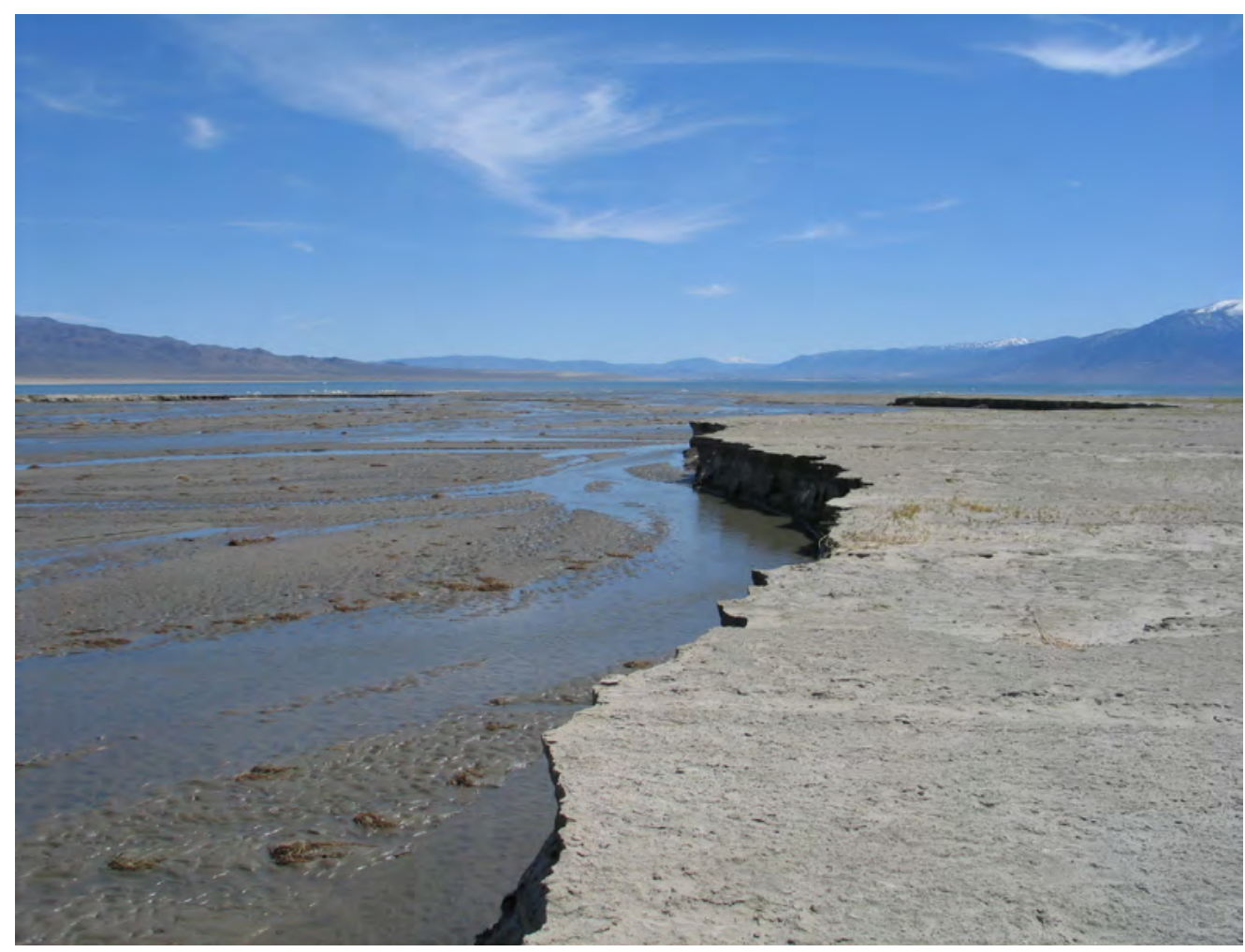

Figure 7. Vew looking south at Walker Lake from the mouth of the Walker River, Nevada. (Photograph taken by Thomas J. Lopes, April 23, 2004.)

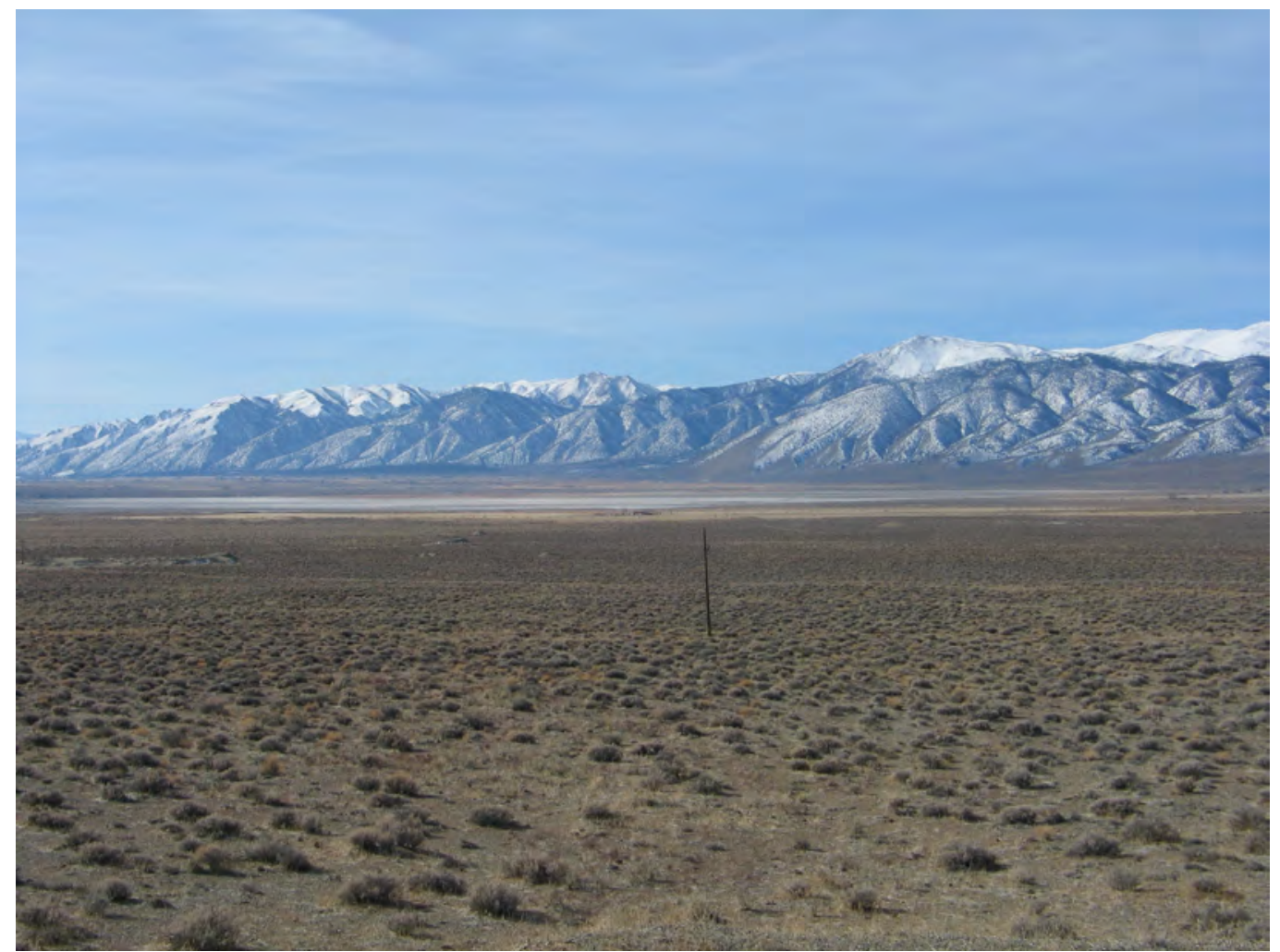

Figure 8. View from northeastern Smith Valley looking southwest towards Artesia Lake and the Pine Nut Range, Nevada. (Photograph taken by Thomas J. Lopes, February 6, 2008.) 


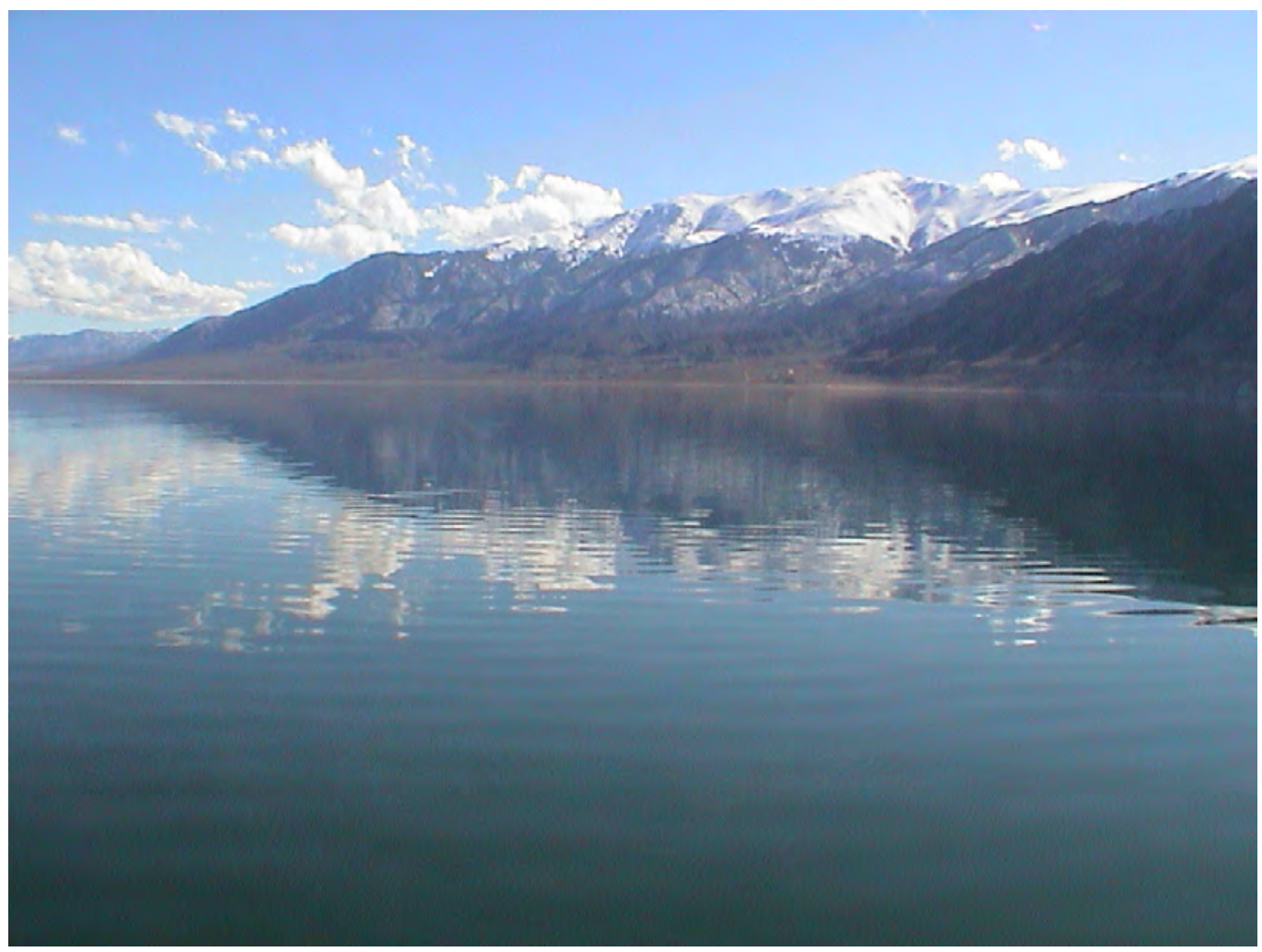

Figure 9. View from Walker Lake looking southwest at Mount Grant, Nevada. (Photograph taken by Thomas J. Lopes, February 28, 2005.)

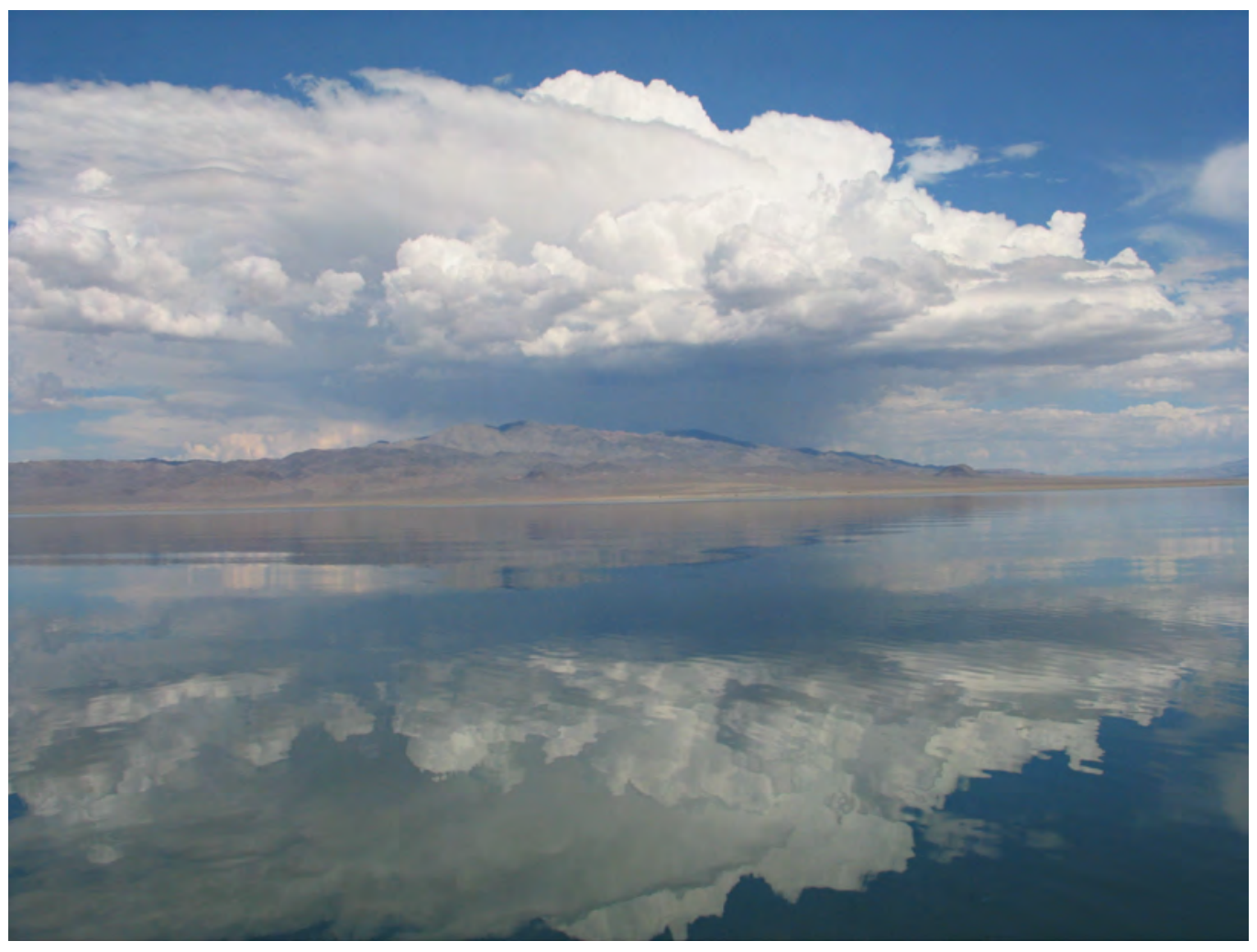

Figure 10. View from Walker Lake looking east at a thunderstorm over the Gillis Range, Nevada. (Photograph taken by Thomas J. Lopes, July 25, 2007.) 


\section{Climate}

Precipitation in Nevada is highly variable temporally and spatially. Winter cold fronts and summer monsoons are the two seasonal weather patterns that bring precipitation to Nevada (Houghton and others, 1975). Cold fronts typically are long-duration, low-intensity, broad storms that account for about 75 percent of the annual precipitation in the Walker River basin. Monsoons typically are short-duration, highintensity, localized thunderstorms that account for about 25 percent of the annual precipitation in the Walker River basin. Months with no precipitation are common between cold fronts and monsoons.

Lopes and Medina (2007) estimated the distribution of precipitation in the Walker River basin and surrounding areas of west-central Nevada. Mean annual precipitation for the period 1971-2000 ranges from about 4 in. at Walker Lake to 56 in. along the crest of the Sierra Nevada. Mean annual precipitation at Mount Grant, the highest mountain adjacent to Walker Lake, is about $16 \mathrm{in} / \mathrm{yr}$. However, mean annual precipitation is an average of dry and wet periods and seldom occurs during any particular year.

The State of Nevada divided major hydrographic basins into 232 hydrographic areas (HAs) for planning and management purposes (Cardinalli, 1968; Rush, 1968). The Walker River basin is comprised of HA 106 (Antelope Valley), HA 107 (Smith Valley), HA 108 (Mason Valley), HA 109 (East Walker Area) and HA 110 (Walker Lake Valley). HA 110 was divided into the Schurz Subarea (HA 110A), Lake Subarea (HA 110B), and Whisky Flat-Hawthorne Subarea (HA 110C). Lopes and Medina (2007) used topographic divides to extend the boundaries of HA 106 and HA 109 to the crest of the Sierra Nevada in California and calculated the total volume of precipitation for the five HAs (table 1). HA 106 and HA 109 receive the largest amount of precipitation in the Walker River basin, especially for precipitation greater than $24 \mathrm{in} / \mathrm{yr}$. Precipitation volumes were 18 percent less than the Parameter-elevation Regressions on Independent Slopes Model (PRISM; Daly and others, 1994), which is another source of precipitation estimates for the Walker River basin.

Mean minimum and maximum temperatures in the Walker River basin range from 25 to $95^{\circ} \mathrm{F}$, respectively, in Hawthorne, Nev., and from 6 to $77^{\circ} \mathrm{F}$, respectively, in Bodie, Calif. The minimum recorded temperature is about $-30^{\circ} \mathrm{F}$ and the maximum is $110^{\circ} \mathrm{F}$. July is the hottest month and December typically is the coldest month. Average wind speed is from about 3 to $5 \mathrm{mi} / \mathrm{h}$ on the valley floor of the lower Walker River basin and $9 \mathrm{mi} / \mathrm{h}$ on Walker Lake. Walker Lake is known for strong winds that can capsize boats and close Highway 95. The predominant wind direction is from the southwest.
Table 1. Mean annual precipitation volumes for hydrographic areas in the Walker River basin, California and Nevada, 1971-2000.

[Values are in acre-feet per year. Volumes estimated using the precipitationzone method (Lopes and Medina, 2007). Abbreviations: LCL, lower 95th-percentile confidence limit of mean; UCL, upper 95th-percentile confidence limit of mean]

\begin{tabular}{lccc}
\hline \multicolumn{1}{c}{ Hydrographic area } & LCL & Mean & UCL \\
\hline 106 (Antelope Valley) & 552,000 & 591,000 & 630,000 \\
107 (Smith Valley) & 295,000 & 319,000 & 342,000 \\
108 (Mason Valley) & 152,000 & 164,000 & 176,000 \\
109 (East Walker Area) & 737,000 & 786,000 & 835,000 \\
110 (Walker Lake Valley) & 452,000 & 487,000 & 520,000 \\
\hline
\end{tabular}

\section{Native, Invasive, and Agricultural Vegetation}

Native vegetation in the lower Walker River basin includes scrub brush, riparian, and pinyon-juniper woodland communities. The scrub brush community is prevalent on the valley floor except along the river and relies mostly on direct precipitation. Plants transpire shallow groundwater in some areas.

The riparian community grows along the lower Walker River where there is abundant water, just south of Walker Lake in an area of groundwater discharge, and along perennial streams in the Wassuk Range. The riparian community can be dense and lush with cottonwood trees, willow and other shrubs, and a variety of grasses. The riparian community abruptly changes to invasive saltcedar 2-3 mi south of Schurz where alkaline lake clays became exposed as Walker Lake receded.

The pinyon-juniper woodland community grows in the Wassuk Range at altitudes between $5,500 \mathrm{ft}$ and $9,000 \mathrm{ft}$ where precipitation ranges from about 7 to $13 \mathrm{in} / \mathrm{yr}$. Sagebrush also grows in open areas and between the pinyon pine and juniper trees. The pinyon-juniper woodland community relies on direct precipitation for its water needs.

Mason Valley has long been the largest agricultural area in the Walker River basin. Most of Mason Valley was mapped as agricultural by Russell (1885), who described "irrigable lands where abundant harvests are annually secured." In 2000 , a total of 88,600 acres of irrigated land was mapped in the Walker River basin (fig. 11). Total irrigated land included 39,100 acres (44 percent) in Mason Valley; 18,900 acres (21 percent) in Smith Valley; 15,900 acres (18 percent) upstream from Bridgeport Reservoir; 7,700 acres (9 percent) in Antelope Valley; 3,500 acres (4 percent) along the East Fork of the Walker River below Bridgeport Reservoir; 3,000 acres 


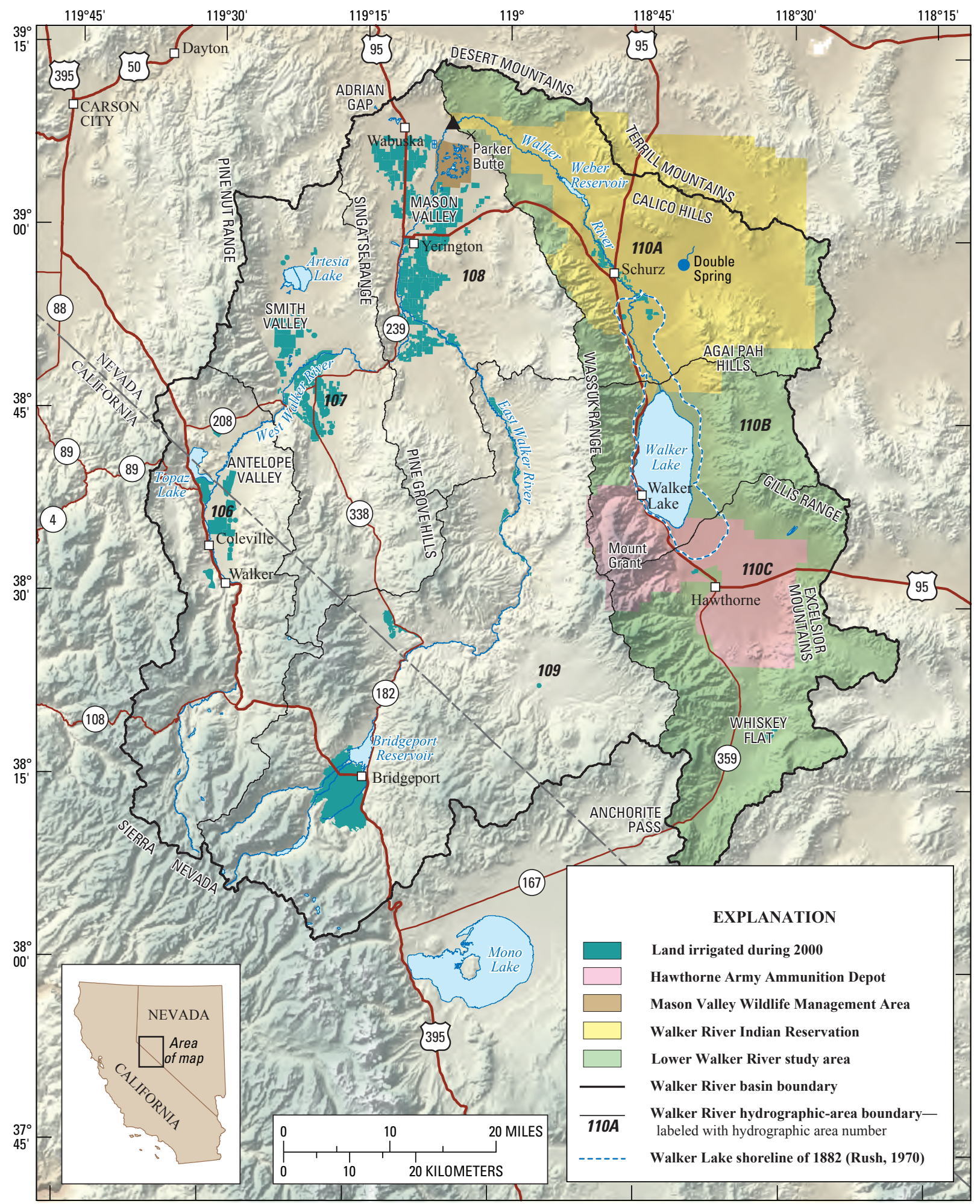

Base from U.S. Geological Survey digital data, 1:24,000 and 1:100,000, 1978-88. Walker Lake average lake altitude of $3937.5 \mathrm{ft}$ for November 2006; Projection: Universal Transverse Shuttle Radar Topography Mission digital data, 2000.

Figure 11. Distribution of 88,600 acres of irrigated land in the Walker River basin, California and Nevada, during the 2000 growing season. 
(3 percent) on the Reservation; and 500 acres (less then 1 percent) in Whisky Flat south of Hawthorne, Nev. The primary crop in the basin is alfalfa, except upstream from Bridgeport Reservoir where fields are irrigated for pasture grass (fig. 5).

\section{Population}

The population of the Walker River basin from the 2000 census was 18,682 (GeoLytics, Inc., 2001). Yerington, Nev., the Lyon County seat, is the largest town in the basin with a population of 3,257 (Hardcastle, 2006). Mason Valley, which includes Yerington, has a total population of 9,886 and Smith Valley has a total population of 1,788. Hawthorne, Nev., the Mineral County seat, has a population of 2,931. Schurz, Nev., is the only town on the Reservation and has a population of 721. Most of the population depends on agriculture to support their livelihood. Other major employers are the Hawthorne Army Ammunition Depot (Army Depot); State, and local Governments; and mining. The towns of Topaz Lake, Nev. (population 2,128), Bridgeport, Calif. (population 817), and Walker Lake, Nev. (population 391), depend on outdoor recreation and tourism.

\section{Previous Investigations}

Water budgets for the lower Walker River basin and Walker Lake have been computed by Harding (1965), Everett and Rush (1967), Rush (1970), Schaefer (1980), Milne (1987), and Thomas (1995). In addition, the State of Nevada summarized streamflow, lake, and reservoir gaging records (Pahl, 1997), summarized surface-water irrigation diversions (Pahl, 2000a), and computed a surface-water budget for the Walker River basin (Pahl, 2000b). For this report, waterbudget estimates were summarized in chronological order of publication.

Harding (1965) estimated the evaporation rate for selected closed-basin lakes as a residual of a water budget. Harding (1965) assumed that evaporation is the only outflow from closed-basin lakes and subsurface inflow is negligible. Thus, the annual volume that evaporates from the lake surface $\left(V_{e}\right)$ is:

$$
V_{e}=V_{s w}+V_{p p t}+\Delta_{s},
$$

where

$V_{s w}$ is the annual volume of streamflow into the lake;

$V_{p p t}$ is the annual volume of precipitation on the lake; and

$\Delta_{s}$ is the annual change in lake storage (positive for a declining lake).

The annual evaporation rate is estimated by dividing $V_{e}$ by the lake surface area. Harding (1965) estimated an average evaporation rate of $4.10 \mathrm{ft} / \mathrm{yr}$ from Walker Lake. This estimate compared well to estimates for Pyramid Lake (4.02 ft/yr) and Winnemucca Lake (3.98 ft/yr), which have a climate and altitude similar to Walker Lake. Harding's estimate is biased low because there is subsurface inflow to Walker Lake (Everett and Rush, 1967; Schaefer, 1980; Lopes and Allander, 2009).

Everett and Rush (1967) computed a water budget for the lower Walker River basin, including Whisky Flat south of Hawthorne, Nev. Average annual flows were calculated for the period 1908-65. Average flow at the Wabuska gage was estimated to be 140,000 acre-ft/yr. The method described by Moore (1968) was used to estimate 10,000 acre-ft/yr of runoff and an average runoff coefficient of $1.3 \mathrm{in} / \mathrm{yr}$ for the Whisky Flat-Hawthorne area. Runoff from the Wassuk Range from Cat Creek and north was estimated to be 5,000 acre-ft/yr with an average runoff coefficient of $1.9 \mathrm{in} / \mathrm{yr}$. Measured runoff from Cottonwood, Rose, and Squaw Creeks indicates these estimates are too high (Boyle Engineering Corp., 1976).

About 2,000 acre-ft/yr of runoff from Cat Creek and north is diverted to the Army Depot (Everett and Rush, 1967). Everett and Rush (1967) estimated 3,000 acre-ft/yr of runoff reaches Walker Lake, which includes 1,000 acre-ft/yr from the Whisky Flat-Hawthorne area and 2,000 acre-ft/yr from Cat Creek and north. The remaining 1,000 acre-ft/yr of runoff from Cat Creek and north is stored in reservoirs or evaporates.

Everett and Rush (1967) used the Maxey-Eakin method (Maxey and Eakin, 1949) to estimate 2,000 acre-ft/yr of recharge in the Whisky Flat area, 3,400 acre-ft/yr around the town of Hawthorne, 500 acre-ft/yr along the Wassuk Range north of Walker Lake, and $600 \mathrm{acre-ft/yr}$ along the Gillis 
Range east of Walker Lake. Recharge west of Walker Lake was assumed to be negligible because the steep consolidated rocks extend to the lake. Thus, runoff that might become recharge flows directly into the lake. However, some recharge occurs because the town of Walker Lake obtains all their water from domestic and municipal wells.

Everett and Rush (1967) note that between 1908 and 1965 the water table declined an average of $40 \mathrm{ft}$ over a $40 \mathrm{mi}^{2}$ area south of Walker Lake. Based on this decline and a specific yield of 15 percent, they estimated subsurface inflow to the lake is 2,000 acre-ft/yr. No information existed for areas north and east of Walker Lake, but Everett and Rush (1967) estimated a combined 1,000 acre-ft/yr from these areas for a total of 3,000 acre-ft/yr of subsurface inflow.

Everett and Rush (1967) used Harding's (1965) rate of $4.10 \mathrm{ft} / \mathrm{yr}$ to estimate 220,000 acre-ft/yr of evaporation. Average storage loss was estimated to be 100,000 acre-ft/yr.

Prior to 1935 , about 9,450 acre-ft/yr of streamflow was diverted to irrigate 2,100 acres on the Reservation (Everett and Rush, 1967). After Weber Dam was completed in 1934, diversions increased to $31,900 \mathrm{acre}-\mathrm{ft} / \mathrm{yr}$ and irrigated land increased to 6,280 acres. Irrigated acreage has since decreased to 3,000 acres that was mapped in 2000 (Lopes and Allander, 2009).

Everett and Rush (1967) used published ET rates to estimate 16,000-17,000 acre-ft/yr of ET in the Schurz area, $800 \mathrm{acre}-\mathrm{ft} / \mathrm{yr}$ around Walker Lake, and 4,600 acre- $\mathrm{ft} / \mathrm{yr}$ in the Whisky Flat area. The rounded total is 22,000 acre- $\mathrm{ft} / \mathrm{yr}$, but the total is 21,000 acre-ft/yr in table 5 of Everett and Rush (1967). Pumpage by municipal wells in Hawthorne and the Army Depot was estimated to be 440 acre-ft/yr. About $300 \mathrm{acre}-\mathrm{ft} / \mathrm{yr}$ was pumped in 1965 to irrigate 100 acres in the Whisky Flat area. Pumpage for all uses in the Schurz area was estimated to be 200 acre-ft/yr.

Total inflow to the lower Walker River basin was estimated to be $169,000 \mathrm{acre}-\mathrm{ft} / \mathrm{yr}$, total outflow was $256,000 \mathrm{acre}-\mathrm{ft} / \mathrm{yr}$, and total storage loss was 103,000 acre-ft/yr (Everett and Rush, 1967). However, errors were found in the water budget. Total inflow was based on 3,000 acre-ft/yr of runoff into Walker Lake but local runoff was estimated to be $15,000 \mathrm{acre}-\mathrm{ft} / \mathrm{yr}$. Total outflow was based on 21,000 instead of 22,000 acre-ft/yr of ET. Harding's (1965) evaporation rate assumes no groundwater inflow but the water budget includes this component, so groundwater was accounted for twice.

In addition to making a bathymetric map, Rush (1970) computed a water budget for Walker Lake based on a 50-year period (1919-68). Rush (1970) estimated 85,000 acre-ft/yr of discharge from the Walker River and a total of 108,000 acre-ft/yr of inflow from all sources.
Harding's (1965) evaporation rate of $4.10 \mathrm{ft} / \mathrm{yr}$ was used to estimate 200,000 acre- $\mathrm{ft} / \mathrm{yr}$ of evaporation. Storage loss was estimated to be 110,000 acre-ft/yr. The difference between evaporation and storage loss $(90,000 \mathrm{acre}-\mathrm{ft} / \mathrm{yr})$ is inflow estimated as a residual, which is $18,000 \mathrm{acre}-\mathrm{ft} / \mathrm{yr}$ less than inflow estimated directly. Rush (1970) attributed the imbalance to errors in the estimates and "unresolved hydrologic problems." One error was including subsurface inflow and using Harding's evaporation rate, which assumed no subsurface inflow.

Schaefer (1980) conducted a water-resource assessment of the Reservation and estimated 116,000 acre-ft/yr of inflow and outflow. Inflow from the Walker River at the Wabuska gage was estimated to be $113,800 \mathrm{acre}-\mathrm{ft} / \mathrm{yr}$. The remaining inflow is subsurface inflow and precipitation.

Schaefer (1980) estimated 69,600 acre-ft/yr of outflow from the Walker River to Walker Lake. The total stream loss of 44,000 acre-ft/yr is about 40 percent of streamflow entering the Reservation. Subsurface outflow was estimated to be 11,000 acre-ft/yr to the northern end of Walker Lake and 4,500 acre-ft/yr through Double Spring and out of the Walker River basin. ET from native vegetation was estimated to be 19,100 acre-ft/yr and 12,000 acre-ft/yr from irrigated lands. Evaporation from the Walker River and Weber Reservoir was estimated to be 3,800 acre-ft/yr. Pumpage by domestic and stock wells was estimated to be $250 \mathrm{acre}-\mathrm{ft} / \mathrm{yr}$.

Milne (1987) estimated what the levels of Walker Lake and other lakes in the Great Basin would have been if there were no human influences on streamflow. As part of the study, Milne (1987) used the water-budget method and assumed negligible groundwater inflow to estimate an evaporation rate of $4.4 \mathrm{ft} / \mathrm{yr}$ for Walker Lake. Milne's model indicated that if the Walker River had not been diverted, then the level of Walker Lake in 1987 would have been near the 1882 level.

Thomas (1995) updated the water budget for Walker Lake based on a 55-yr period (1939-93). Harding's (1965) rate of $4.10 \mathrm{ft} / \mathrm{yr}$ was used to estimate $166,000 \mathrm{acre}-\mathrm{ft} / \mathrm{yr}$ of evaporation. Thomas (1995) used previous estimates of local runoff and subsurface inflow and estimated 17,000 acre-ft/yr of direct precipitation. Storage loss was estimated to be 59,000 acre-ft/yr. Inflow from the Walker River, estimated as a residual of the water budget, was 76,000 acre-ft/yr. An error in the water budget was using Harding's evaporation rate and including subsurface inflow, so groundwater was accounted for twice.

To reduce dissolved solids to $10,000 \mathrm{mg} / \mathrm{L}$, Thomas (1995) estimated 700,000 acre-ft would be needed to raise the lake from 3,944 to 3,964 ft, then 47,000 acre-ft/yr of inflow in addition to average annual inflows would be needed to maintain the lake level. These estimates did not include water needed to replenish aquifer storage. Currently (2008), the lake level is $3,931 \mathrm{ft}$ and about 1,100,000 acre- $\mathrm{ft}$ would be needed to raise the level to $3,964 \mathrm{ft}$. 


\section{Methods}

Water budgets were based on the water year (begins October 1 through September 30 of the stated year). The period 1971-2000 was chosen for mean annual estimates because 30 years generally is considered long enough to represent the long-term average and this period has the most precipitation and streamflow data. In particular, high-altitude precipitation has been monitored at SNOwpack TELemetry (SNOTEL) stations since about 1980 by the Natural Resources Conservation Service. Also, current water use and lake-storage changes are best represented using the most recent 30-year period.

Statistical techniques that were used included summary statistics, correlation, and regression analysis (Helsel and Hirsch, 1992). A 95-percent level of confidence was used in all statistical tests.

\section{Precipitation Normals}

For this study, a normal is the mean annual value for a 30 -yr period. The method of estimating precipitation normals in the Walker River basin and surrounding areas of westcentral Nevada was described in detail by Lopes and Medina (2007). Briefly, precipitation data, station locations, and station altitudes were obtained for 105 stations in and surrounding the Walker River basin. Data were used to calculate the precipitation normal at each station for the 1971-2000 water years. Only years with complete record were used in all calculations. A complete year is when each month in the water year has less than 6 days of missing data.

One station (Reno) had 30 complete years of precipitation data during 1971-2000 and 19 stations had from 25 to 29 complete years. These 20 stations were called reference stations. It was assumed that the mean of the 25-30 wateryear totals is the precipitation normal for reference stations. Linear regression was used to estimate precipitation normals for the 85 stations with less than 25 complete years of data. Annual precipitation of these stations was correlated with annual precipitation of the 20 reference stations using all years with complete data through 2005 . The reference station that had the highest significant Pearson correlation coefficient $(r)$ was chosen as the independent variable and the station with less than 25 complete years was the dependent variable in linear regression. The 1971-2000 precipitation normal of the reference station and the regression equation were used to estimate the 1971-2000 precipitation normal of the station with less than 25 years of data. The 95-percent confidence limits are a measure of the uncertainty in the normal.
Patterns in the spatial distribution of precipitation were identified by mapping station locations and plotting precipitation normals versus station altitude. Stations in the same geographic area were determined to have precipitation normals that are related linearly to land-surface altitude. Stations with the same linear relation were grouped manually to define a precipitation zone. Four precipitation zones were defined that cover part of east-central California and much of west-central Nevada (fig. 12). Hydrologic-unit boundaries, which define major watersheds, were used to define precipitation-zone boundaries where possible. Where hydrologic-unit boundaries and the boundary between precipitation zones did not coincide, the precipitation-zone boundary was drawn roughly equidistant between stations in different zones. The eastern boundaries of precipitation zones were not delineated because zones extend beyond the stations that were used in this analysis.

Regression equations were developed for each zone to estimate precipitation normals from altitude at any point in the zone (table 2). The regression equations have adjusted coefficients of determination $\left(R^{2}\right)$ of 0.89 to 0.95 , indicating that altitude explains 89-95 percent of the variation in precipitation normals within each zone. The remaining 5-11 percent could be due to uncertainty in estimated precipitation normals.

A geographic information system, 98-ft digital elevation model, and the four regression equations were used to estimate the distribution of mean annual precipitation in westcentral Nevada. The altitude of each cell was used with the corresponding regression equation to estimate precipitation of each cell within a precipitation zone to the nearest inch. Gradational color shading was used to show the distribution in mean annual precipitation (fig. 12).

Table 2. Summary of precipitation zone regression equations.

[Equations are used with land-surface elevation, in feet. Abbreviation: $R^{2}$, coefficient of determination]

\begin{tabular}{lrrrrr}
\hline \multirow{2}{*}{ Zone } & Intercept & Slope & $\begin{array}{c}\text { Adjusted } \\
\boldsymbol{R}^{2}\end{array}$ & \multicolumn{2}{c}{ Mean absolute error } \\
\cline { 5 - 6 } & & & & (inches) & (percent) \\
\hline Carson & -9.2 & 0.00382 & 0.92 & 1.4 & 10 \\
Sierra Slope & -31.0 & .01010 & .89 & 3.9 & 17 \\
Truckee & -21.0 & .00670 & .95 & 2.0 & 12 \\
Walker & -2.3 & .00167 & .90 & .8 & 12 \\
\hline
\end{tabular}




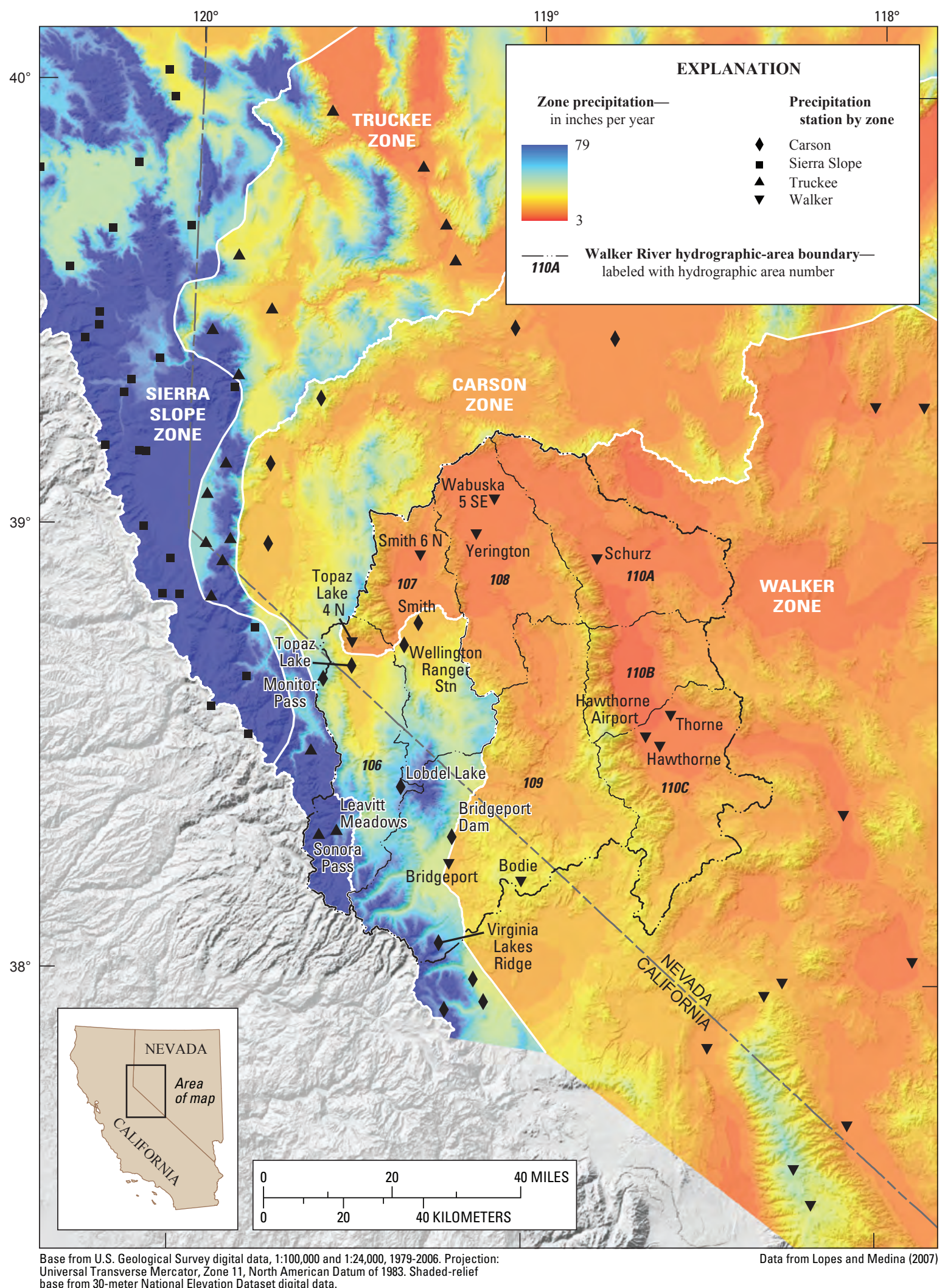

Figure 12. Distribution of precipitation in the Walker River basin, California and Nevada. 


\section{Streamflow Normals at Gaging Stations}

The same approach that was used to estimate precipitation normals was used to estimate 1971-2000 streamflow normals at stream gages in the Walker Basin (fig. 13) and at stream gages in other basins that were used to estimate ungaged runoff. Five gages in the Walker River basin, two gages in the Carson River basin, and two gages in the Toiyabe Range have 30 complete years (1971-2000) of streamflow data. Streamflow normals for these reference gages were the arithmetic mean of the 30 annual-streamflow values (table 3). Reference gages that are upstream from diversions have streamflow normals with uncertainties that range from 18 to 25 percent with a mean of 20 percent. The Wabuska gage has an uncertainty of 37 percent due to upstream diversions and reservoir storage.

For gages with less than 30 years of record, annual streamflow was correlated with annual streamflow of reference gages in the same drainage basin or the closest reference gages. Streamflow data collected by the Army Depot were used for Rose, Cottonwood, and Squaw Creeks (table 4). The reference gage that had the highest significant Pearson correlation coefficient was chosen as the independent variable and the gage with incomplete record was the dependent variable in linear regression. The 1971-2000 streamflow normal of the reference gage and the regression equation were used to estimate the streamflow normal of the gage with less than 30 years of record (table 5). For example, the streamflow normal $(\bar{\chi})$ at Virginia Creek near Bridgeport, Calif. (10289000) is 13,000 acre-ft/yr:

$$
\bar{\chi}=4,400+0.063 * 138,000
$$

where

4,400 is the intercept of the regression equation;

0.063 is the slope; and

138,000 is the $1971-2000$ streamflow normal, in acre-ft/yr, of the reference station (10301500; tables 3, 5).

Regression equations for streamflow gages in the Walker River basin had adjusted $R^{2}$ values of 0.90 to 1.0. Diversion gages Canal No. 1 below Little Dam (Canal No. 1 gage, 10301755) and Canal No. 2 above Little Dam (Canal No. 2 gage, 10301742) had adjusted $R^{2}$ values of 0.79 and 0.78 , respectively. Names of the Canal No. 1 gage and the Walker River above Little Dam near Schurz (Little Dam gage, 10301745), are misleading because they indicate the wrong location relative to Little Dam. Both diversions are upstream from Little Dam, and the Little Dam gage actually measures discharge downstream from Little Dam.

Table 3. Streamflow normals at selected gaging stations with 30 complete years of data, Walker and Carson River basins and Toiyabe Range, California and Nevada, 1971-2000.

[Abbreviations: Calif., California; LCL, lower 95th-percentile confidence limit; MSL, mean sea level; Nev., Nevada; UCL, upper 95th-percentile confidence limit; $\mathrm{mi}^{2}$, square mile; acre-ft/yr, acre-foot per year]

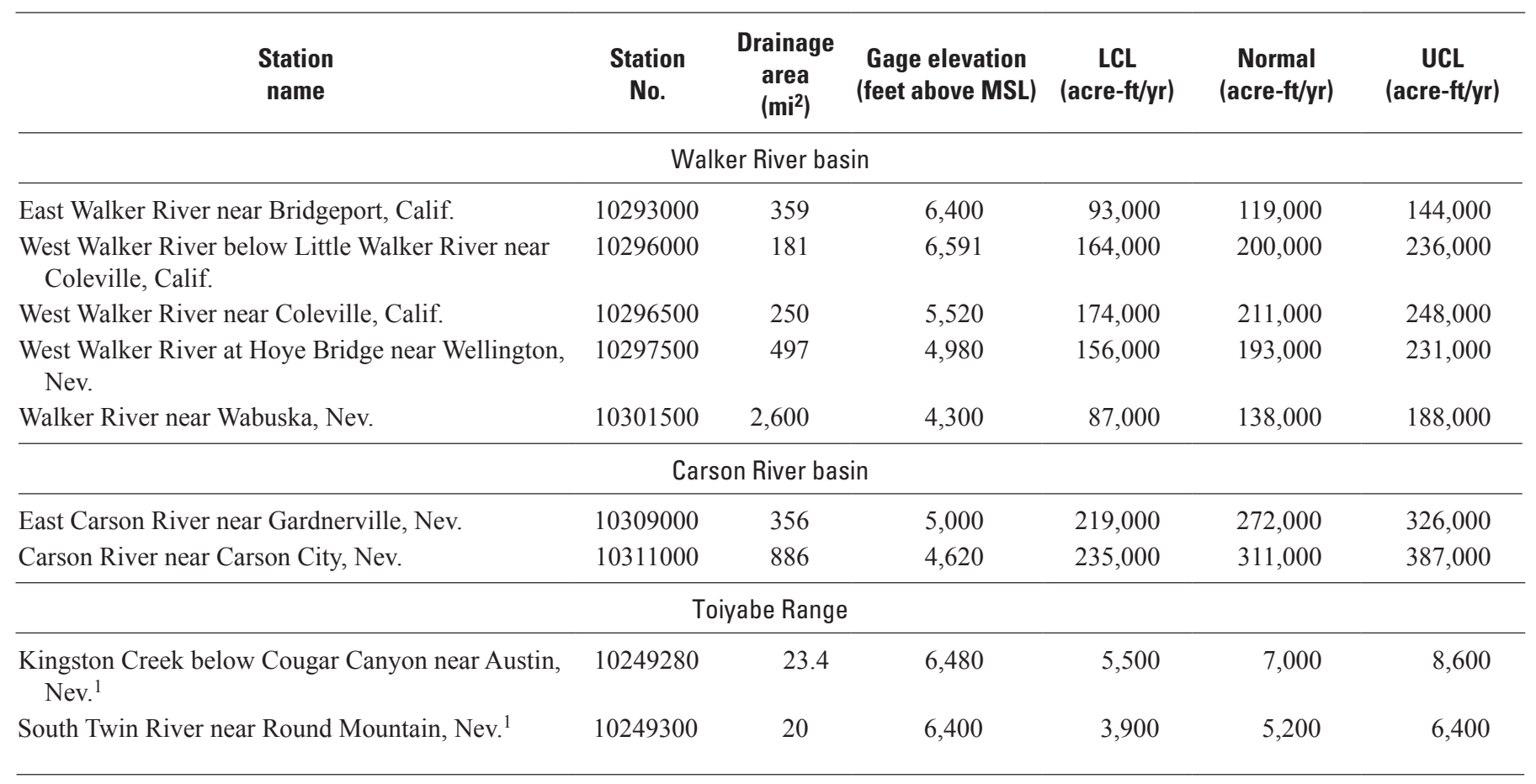

\footnotetext{
${ }^{1}$ Station used to estimate streamflow from ungaged basins.
} 


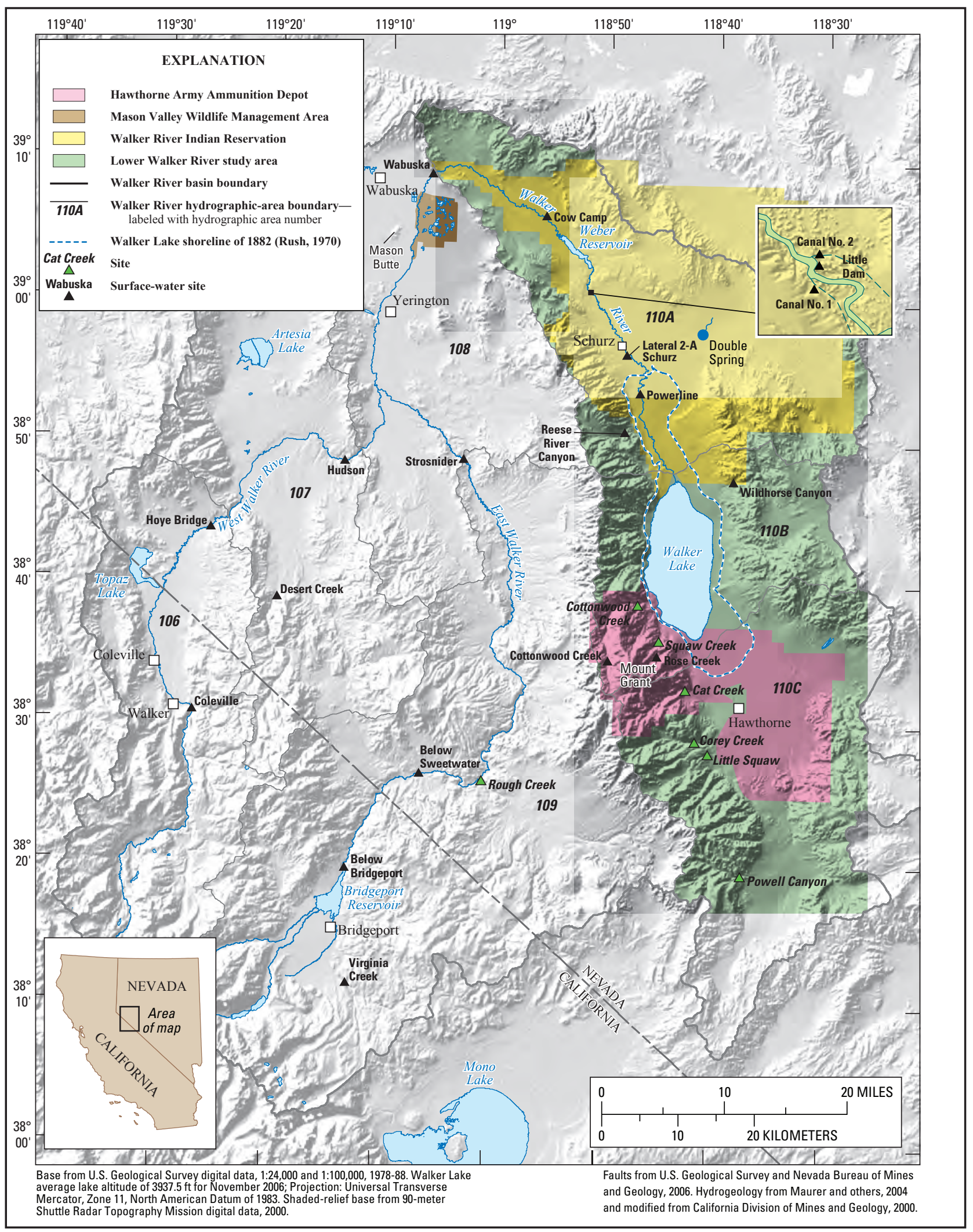

Figure 13. Locations of stream gages in the Walker River basin, California and Nevada. 
Table 4. Streamflow data from drainages in the Wassuk Range, Nevada.

[Data were collected by the Hawthorne Army Ammunition Depot and reported by Boyle Engineering, Corp. (1976). Values in acre-feet. Abbreviations: CY, calendar year; WY, water year (October 1 through September 30); -, does not apply]

\begin{tabular}{|c|c|c|c|c|c|c|c|}
\hline Year & January & February & March & April & May & June & July \\
\hline \multicolumn{8}{|c|}{ Cottonwood Creek } \\
\hline 1971 & 10 & 22 & 36 & 51 & 89 & 119 & 133 \\
\hline 1972 & 29 & 22 & 52 & 138 & 120 & 96 & 33 \\
\hline 1973 & 3 & 5 & 16 & 32 & 57 & 80 & 107 \\
\hline 1974 & 37 & 62 & 74 & 65 & 100 & 122 & 92 \\
\hline 1975 & 5 & 15 & 37 & 41 & 117 & 270 & 113 \\
\hline \multicolumn{8}{|c|}{ Rose Creek } \\
\hline 1971 & 65 & 55 & 50 & 50 & 45 & 90 & 121 \\
\hline 1972 & 86 & 72 & 79 & 74 & 45 & 64 & 32 \\
\hline 1973 & 50 & 34 & 29 & 64 & 135 & 220 & 135 \\
\hline 1974 & 62 & 43 & 25 & 40 & 71 & 61 & 24 \\
\hline 1975 & 10 & 13 & 16 & 17 & 47 & 117 & 31 \\
\hline \multicolumn{8}{|c|}{ Squaw Creek } \\
\hline 1971 & 10 & 11 & 14 & 11 & 14 & 19 & 9 \\
\hline 1972 & 9 & 9 & 7 & 6 & 8 & 7 & 3 \\
\hline 1973 & 7 & 7 & 7 & 5 & 16 & 19 & 17 \\
\hline 1974 & 59 & 59 & 58 & 65 & 59 & 58 & 33 \\
\hline 1975 & 51 & 58 & 51 & 47 & 51 & 90 & 74 \\
\hline Year & August & September & October & November & December & $\mathrm{CY}$ total & WY total \\
\hline \multicolumn{8}{|c|}{ Cottonwood Creek } \\
\hline 1971 & 84 & 33 & 44 & 14 & 5 & 640 & - \\
\hline 1972 & 26 & 21 & 36 & 50 & 12 & 635 & 600 \\
\hline 1973 & 111 & 113 & 86 & 19 & 10 & 639 & 622 \\
\hline 1974 & 42 & 13 & 10 & 3 & 5 & 625 & 722 \\
\hline 1975 & 103 & 62 & 37 & 12 & 12 & 824 & 781 \\
\hline \multicolumn{8}{|c|}{ Rose Creek } \\
\hline 1971 & 41 & 37 & 41 & 95 & 80 & 770 & - \\
\hline 1972 & 22 & 25 & 34 & 74 & 77 & 684 & 715 \\
\hline 1973 & 46 & 37 & 43 & 54 & 78 & 925 & 935 \\
\hline 1974 & 11 & 10 & 14 & 67 & 41 & 469 & 522 \\
\hline 1975 & 25 & 33 & 21 & 20 & 18 & 368 & 431 \\
\hline \multicolumn{8}{|c|}{ Squaw Creek } \\
\hline 1971 & 5 & 5 & 7 & 10 & 9 & 124 & - \\
\hline 1972 & 2 & 3 & 5 & 7 & 7 & 73 & 80 \\
\hline 1973 & 16 & 16 & 17 & 18 & 12 & 157 & 129 \\
\hline 1974 & 29 & 28 & 37 & 44 & 52 & 581 & 495 \\
\hline 1975 & 60 & 60 & 57 & 62 & 61 & 722 & 675 \\
\hline
\end{tabular}


Table 5. Estimated streamflow normals at selected gaging stations with less than 30 complete years of data, California and Nevada, 1971-2000.

[Abbreviations: MSL, mean sea level; SEE, standard error of estimate; LCL, lower 95th-percentile confidence limit; UCL, upper 95th-percentile confidence limit; USGS, U.S. Geological Survey; *, station used to estimate streamflow from ungaged basins; acre-ft/yr; acre-foot per year; mi $^{2}$, square mile; -, does not apply]

\begin{tabular}{|c|c|c|c|c|c|c|c|c|c|c|c|}
\hline \multirow[t]{2}{*}{ Station name } & \multirow{2}{*}{$\begin{array}{c}\text { USGS } \\
\text { station } \\
\text { No. }\end{array}$} & \multirow{2}{*}{$\begin{array}{c}\text { Drainage } \\
\text { area } \\
\left(\mathrm{mi}^{2}\right)\end{array}$} & \multirow{2}{*}{$\begin{array}{c}\text { Gage } \\
\text { elevation } \\
\text { (feet above } \\
\text { MSL) }\end{array}$} & \multirow{2}{*}{$\begin{array}{c}\text { Reference } \\
\text { station } \\
\text { No. }\end{array}$} & \multirow[t]{2}{*}{ Intercept } & \multirow[t]{2}{*}{ Slope } & \multirow{2}{*}{$\begin{array}{l}\text { Adjusted } \\
\qquad R^{2}\end{array}$} & SEE & LCL & $\begin{array}{c}\text { Estimated } \\
\text { normal }\end{array}$ & UCL \\
\hline & & & & & & & & \multicolumn{4}{|c|}{ (acre-ft/yr) } \\
\hline \multicolumn{12}{|c|}{ East Fork of the Walker River } \\
\hline Virginia Creek near Bridgeport, Calif.* & 10289000 & 63.6 & 6,750 & 10301500 & 4,400 & 0.063 & 0.94 & 1,400 & 12,000 & 13,000 & 14,000 \\
\hline Green Creek near Bridgeport, Calif. & 10289500 & 19.5 & 6,880 & 10296500 & 2,200 & .095 & .98 & 1,100 & 22,000 & 22,000 & 23,000 \\
\hline Robinson Creek near Twin Lakes, Calif. & 10290500 & 39.1 & 7,050 & 10297500 & 12,000 & .18 & .96 & 2,700 & 45,000 & 46,000 & 47,000 \\
\hline Buckeye Creek near Bridgeport, Calif. & 10291500 & 44.1 & 6,900 & 10296500 & 2,300 & .21 & .96 & 3,300 & 45,000 & 46,000 & 47,000 \\
\hline Swauger Creek near Bridgeport, Calif.* & 10292000 & 52.8 & 6,620 & 10301500 & 2,200 & .058 & .90 & 1,900 & 9,000 & 10,000 & 11,000 \\
\hline $\begin{array}{l}\text { East Walker River below Sweetwater } \\
\text { Creek, Calif. }\end{array}$ & 10293050 & 467 & 5,760 & 10297500 & 6,200 & .64 & .98 & 8,100 & 120,000 & 129,000 & 137,000 \\
\hline $\begin{array}{l}\text { East Walker River above Strosnider } \\
\text { Ditch near Mason, Nev. }\end{array}$ & 10293500 & 1,100 & 4,574 & 10293000 & $-17,600$ & 1.2 & .99 & 6,800 & 120,000 & 122,000 & 124,000 \\
\hline West Walker River near Wellington, Nev. & 10298500 & 521 & 4,850 & 10301500 & 89,700 & .63 & 1.00 & 1,900 & 162,000 & 176,000 & 190,000 \\
\hline Desert Creek near Wellington, Nev.* & 10299100 & 50.4 & 5,840 & 10301500 & 1,500 & .049 & .97 & 1,300 & 5,000 & 8,000 & 11,000 \\
\hline West Walker River near Hudson, Nev. & 10300000 & 964 & 4,650 & 10297500 & $-19,200$ & .86 & .96 & 14,400 & 142,000 & 147,000 & 152,000 \\
\hline \multicolumn{12}{|c|}{ Walker River } \\
\hline Walker River near Mason, Nev. & 10300600 & 2,400 & 4,420 & 10301500 & 54,500 & 1.04 & 0.99 & 21,700 & 181,000 & 198,000 & 214,000 \\
\hline $\begin{array}{l}\text { Canal No. } 2 \text { above Little Dam near } \\
\text { Schurz, Nev. }\end{array}$ & 10301742 & - & 4,160 & 10301500 & 5,700 & .040 & .78 & 1,800 & 9,000 & 11,000 & 13,000 \\
\hline $\begin{array}{l}\text { Walker River above Little Dam near } \\
\text { Schurz, Nev. }\end{array}$ & 10301745 & 2,584 & 4,160 & 10301500 & $-8,600$ & .87 & .98 & 11,300 & 96,000 & 111,000 & 126,000 \\
\hline
\end{tabular}

\begin{tabular}{|c|c|c|c|c|c|c|c|c|c|c|c|}
\hline \multicolumn{12}{|c|}{ Wassuk and Gillis Ranges } \\
\hline Cottonwood Creek ${ }^{2}$ & & 21.5 & & 10301500 & 450 & .0019 & .85 & 30 & 640 & 720 & 810 \\
\hline Cat Creek & & 19.1 & & - & - & - & - & - & - & ${ }^{3} 270$ & - \\
\hline Corey Creek & & 20.8 & & - & - & - & - & - & - & ${ }^{4} 100$ & - \\
\hline Wildhorse Canyon near Walker Lake* & 10302030 & 63 & 4,400 & - & - & - & - & - & - & ${ }^{5} 50$ & - \\
\hline Bryant Creek near Gardnerville, Nev.* & 10308800 & 31.5 & 5,450 & 10309000 & $-3,300$ & 0.031 & 0.89 & 1,200 & 4,500 & 5,100 & 5,600 \\
\hline Pine Nut Creek near Gardnerville, Nev.* & 10309050 & 10.14 & 6,340 & 10311000 & 120 & .0024 & .63 & 500 & 600 & 900 & 1,100 \\
\hline $\begin{array}{l}\text { Fredericksburg Canyon Creek near } \\
\text { Fredericksburg, Calif.* }\end{array}$ & 10310300 & 3.71 & 5,520 & 10311000 & 700 & .0081 & .62 & 1,300 & 2,400 & 3,200 & 4,100 \\
\hline Daggett Creek near Genoa, Nev.* & 10310400 & 3.82 & 5,100 & 10311000 & 700 & .0019 & .52 & 400 & 1,200 & 1,300 & 1,400 \\
\hline
\end{tabular}


Table 5. Estimated streamflow normals at selected gaging stations with less than 30 complete years of data, California and Nevada, 1971-2000.-Continued

[Abbreviations: MSL, mean sea level; SEE, standard error of estimate; LCL, lower 95th-percentile confidence limit; UCL, upper 95th-percentile confidence limit; USGS, U.S. Geological Survey; *, station used to estimate streamflow from ungaged basins; acre-ft/yr; acre-foot per year; mi², square mile; -, does not apply]

\begin{tabular}{|c|c|c|c|c|c|c|c|c|c|c|c|}
\hline \multirow[t]{2}{*}{ Station name } & \multirow{2}{*}{$\begin{array}{c}\text { USGS } \\
\text { station } \\
\text { No. }\end{array}$} & \multirow{2}{*}{$\begin{array}{c}\text { Drainage } \\
\text { area } \\
\left(\mathrm{mi}^{2}\right)\end{array}$} & \multirow{2}{*}{$\begin{array}{c}\text { Gage } \\
\text { elevation } \\
\text { (feet above } \\
\text { MSL) }\end{array}$} & \multirow{2}{*}{$\begin{array}{c}\text { Reference } \\
\text { station } \\
\text { No. }\end{array}$} & \multirow[t]{2}{*}{ Intercept } & \multirow[t]{2}{*}{ Slope } & \multirow{2}{*}{$\begin{array}{c}\text { Adjusted } \\
R^{2}\end{array}$} & SEE & LCL & $\begin{array}{l}\text { Estimated } \\
\text { normal }\end{array}$ & UCL \\
\hline & & & & & & & & \multicolumn{4}{|c|}{ (acre-ft/yr) } \\
\hline \multicolumn{12}{|c|}{ Carson River basin-Continued } \\
\hline $\begin{array}{l}\text { Kings Canyon Creek near Carson City, } \\
\text { Nev.* }\end{array}$ & 10311100 & 4.06 & 5,180 & 10311000 & 130 & 0.0027 & 0.51 & 600 & 800 & 1,000 & 1,200 \\
\hline $\begin{array}{l}\text { Vicee Canyon Creek near Sagebrush } \\
\text { Ranch near Carson City, Nev.* }\end{array}$ & 10311260 & 1.83 & 5,155 & 10311000 & .0 & .00050 & .88 & 40 & 100 & 200 & 200 \\
\hline \multicolumn{12}{|c|}{ Toiyabe Range, Desatoya and White Mountains } \\
\hline Reese River near Ione, Nev.* & 10325500 & 53 & 7,100 & 10249300 & $-3,000$ & 2.84 & 0.93 & 1,800 & 10,000 & 11,000 & 12,000 \\
\hline \multicolumn{12}{|c|}{${ }^{2}$ Regression equation computed using 1972-75 data collected by Hawthorne Army Ammunition Depot (Boyle Engineering Corp., 1976). } \\
\hline \multicolumn{12}{|c|}{${ }^{3} 1970-75$ average (Boyle Engineering Corp., 1976). } \\
\hline${ }^{4}$ Estimated average from Boyle Engi & ering Corp. & (1976). & & & & & & & & & \\
\hline
\end{tabular}

\section{Streamflow Normals at Ungaged Drainages}

Streamflow is gaged at multiple locations in large, perennial drainages but relatively few small- and intermediatesized drainages have been gaged in Nevada. Runoff-altitude relations (Everett and Rush, 1967; Glancy, 1971), regression equations (Maurer and others, 2004b), and modeling (Jeton and Maurer, 2007) have been used to estimate ungaged streamflow in the Walker and Carson River basins. For this study, a regression equation was developed that relates 1971-2000 streamflow normals to precipitation normals in 19 small- and intermediate-sized gaged drainages in and around the Walker River basin.

Eighteen gaged basins in the Walker and Carson River basins, White and Desatoya Mountains, and the Toiyabe Range were used in the regression analysis (fig. 14; tables 3 , 5). All gages are upstream from diversions and near the consolidated rock-unconsolidated sediment contact. In addition, a streamflow normal of $50 \mathrm{acre}-\mathrm{ft} / \mathrm{yr}$ was assumed for Wildhorse Canyon east of Walker Lake to constrain the regression for intermediate-sized, ephemeral drainages receive less than $10 \mathrm{in} / \mathrm{yr}$ of precipitation.

The 19 drainage basins range in area from about 2 to $64 \mathrm{mi}^{2}$ and generally are underlain by intrusive and volcanic rocks with low hydraulic conductivities (Maurer and others, 2004a). Precipitation normals range from 5 to $45 \mathrm{in} / \mathrm{yr}$ and streamflow normals range from 50 to $13,000 \mathrm{acre}-\mathrm{ft} / \mathrm{yr}$.
Wide ranges in drainage area, precipitation, streamflow, and geographic distribution help characterize runoff from smalland intermediate-sized drainages in west-central Nevada.

Streamflow normals had significant Spearman rank correlations with drainage area $(0.90)$ and total precipitation volume (0.90) but were not significantly correlated with average basin slope, soil permeability, or soil thickness. The Pearson correlation between total precipitation volume and drainage area was 0.87 , so only precipitation was used in the regression analysis.

The volume of precipitation at 1-in. intervals was calculated for each drainage basin. Regressing streamflow normals with volumes at 1 -in. intervals would create a cumbersome equation so volumes were summed for ranges in precipitation, such as 11-14 in/yr. A similar approach was used to estimate groundwater recharge from mean annual precipitation in unmonitored basins (Maxey and Eakin, 1949; Nichols, 2000). Maxey and Eakin (1949) and Nichols (2000) constrained their regression equations to have intercepts equal to zero and coefficients that are positive and increase in value with increasing precipitation. Constraining the regression makes physical sense because the percent of precipitation that becomes recharge and runoff presumably increases with increasing precipitation rates. However, a constrained regression may not perform as well as an unforced regression. Unconstrained and constrained regressions for estimating ungaged runoff were compared for this study. 


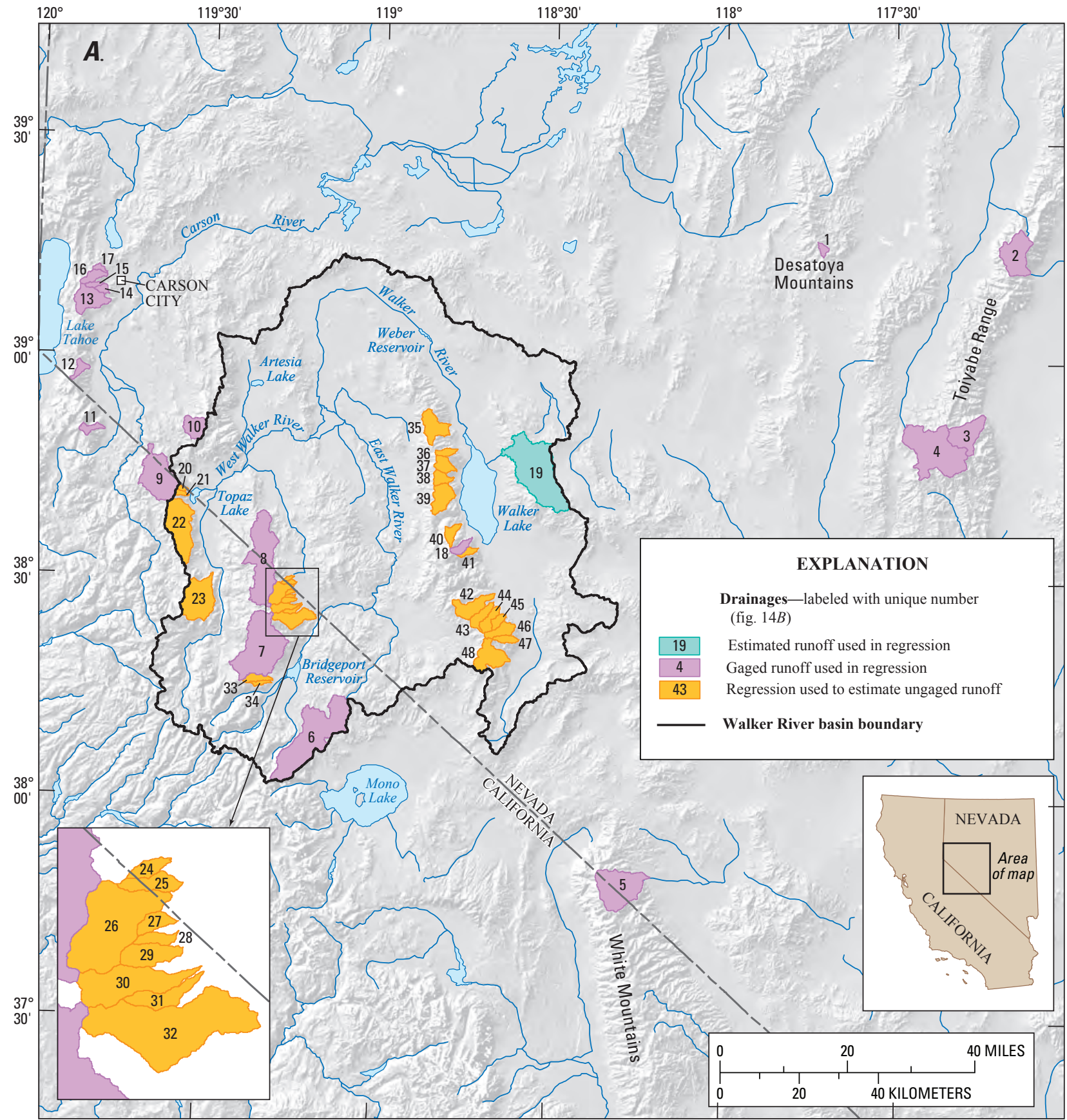

Base from U.S. Geological Survey digital data, 1:100,000 and 1:24,000, 1979-2006 Projection: Universal Transverse Mercator, Zone 11, North American Datum of 1983 Projection: Universal Transverse Mercator, Zone 11, North American Dat.
Shaded-relief base from 30-meter National Elevation Dataset digital data.

Figure 14. Locations of drainages in California and Nevada that were used to estimate runoff from ungaged drainages in the Walker River basin. 


\section{B. Gaged, estimated, and ungaged drainages}

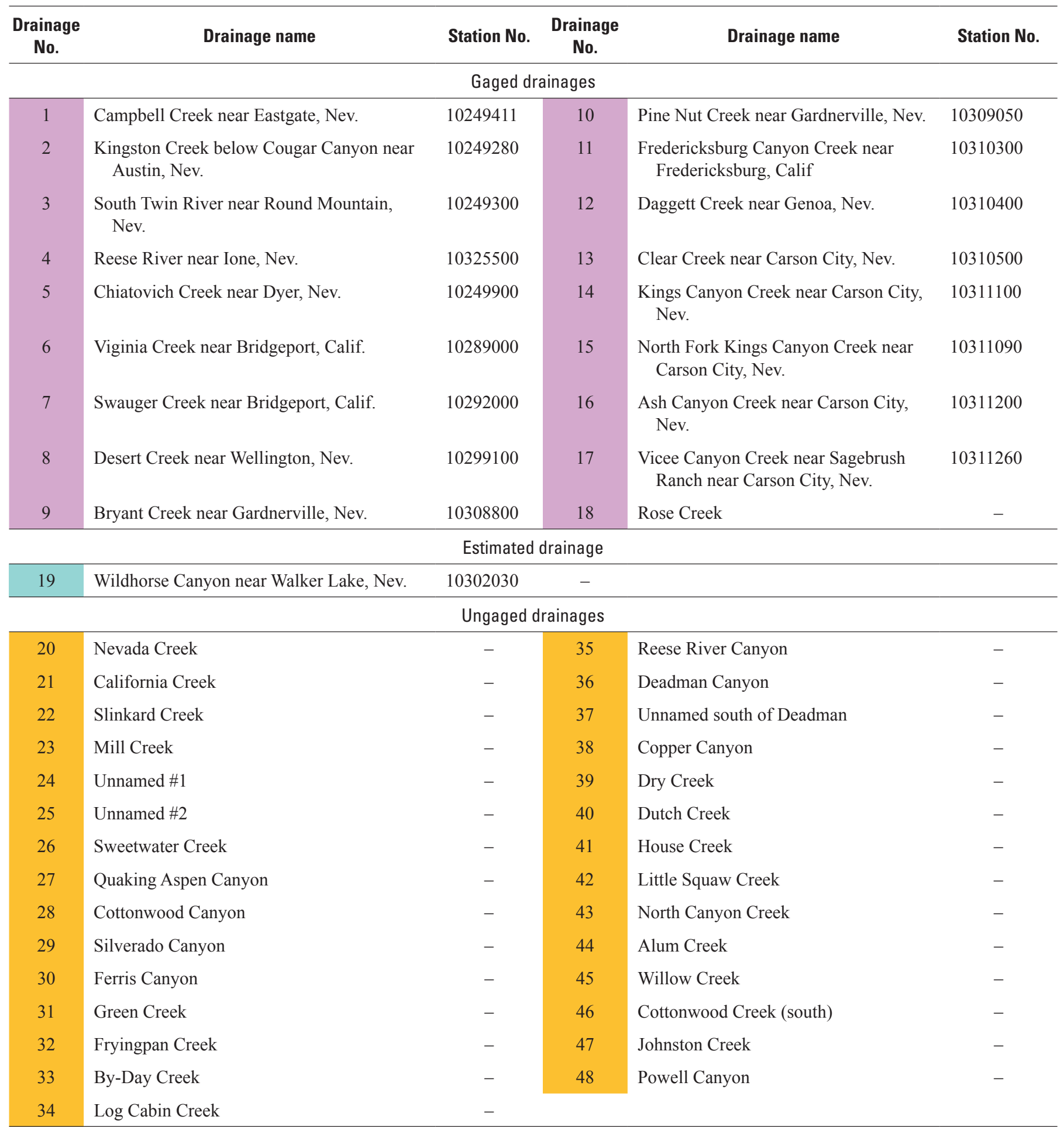

Figure 14.-Continued. 
In most of the 19 drainages precipitation ranges from 11 to $38 \mathrm{in} / \mathrm{yr}$ so less than or equal to $10 \mathrm{in} / \mathrm{yr}$ and greater than $38 \mathrm{in} / \mathrm{yr}$ were the initial bounding intervals. Precipitation volumes were summed at 4-, 6-, and 8-inch intervals between the initial bounding intervals and varying bounding intervals, such as less than or equal to $12 \mathrm{in} / \mathrm{yr}$ and greater than $36 \mathrm{in} / \mathrm{yr}$. The adjusted $R^{2}$, p-value of regression coefficients, standard error of estimate (SEE), and homoscedasticity of residuals were used to determine which intervals and regressions performed best. For comparison, the same procedure was done using PRISM 1971-2000 precipitation estimates.

The regression equation that performed best was for an unconstrained regression using precipitation estimates from Lopes and Medina (2007) and 6-inch intervals between less than or equal to $10 \mathrm{in} / \mathrm{yr}$ and greater than $28 \mathrm{in} / \mathrm{yr}$ :

$$
\begin{aligned}
\bar{\chi}=0.0034 * P V_{\leq 10} & +0.3732 * P V_{11-16}-0.0747 * P V_{17-22} \\
& +0.3348 * P V_{23-28}+0.2713 * P V_{>28},
\end{aligned}
$$

where

$$
\bar{\chi} \text { is the streamflow normal, in acre-ft/yr, and }
$$

$P V_{11-16}$ is the precipitation volume from 11

to $16 \mathrm{in} . / \mathrm{yr}$, in acre-ft/yr.

The adjusted $R^{2}$ was 0.98 , the mean absolute error (MAE) was 35 percent, and the SEE was 710 acre-ft/yr (76 percent), indicating equation 3 performs fairly well (fig. 15A).
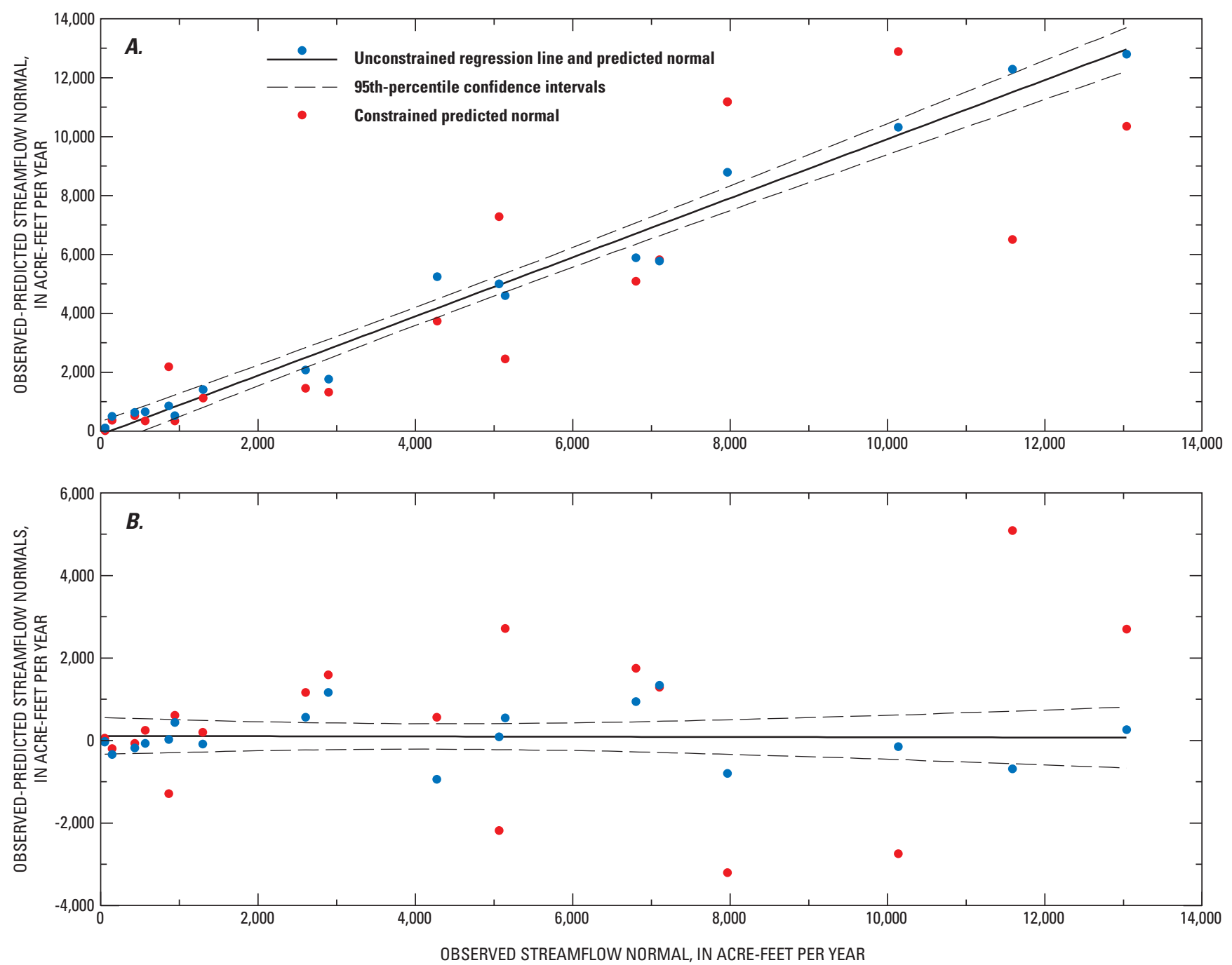

Figure 15. (A) predicted compared to observed 1971-2000 streamflow normals and (B) constrained regressions compared to observed streamflow normals. Solid lines are the regression of predictions or residuals from the unconstrained regression with observed streamflow normals. Dashed lines are the $95^{\text {th }}$-percentile confidence intervals of the regression. 
Regression of residuals with observed values indicates no bias in the estimates for the entire range in streamflow normals, but the lowest values (less than 1,300 acre-ft/yr) tend to be overestimated (fig. 15B).

Constraining the regression resulted in increasing errors with increasing streamflow normals and a SEE of 2,300 acre-ft/yr (fig. 15). The best unconstrained regression using PRISM precipitation estimates had a SEE of 2,180 acre-ft/yr. The negative coefficient for $P V_{17-22}$ in equation 3 makes no physical sense. However, the purpose of the regression was to calculate an equation that best predicts runoff, so equation 3 and the precipitation distribution (fig. 12) were used to estimate ungaged runoff in the Walker River basin (table 6). Negative estimates were assumed to be equal to zero. Equation 3 should be used only with precipitation estimates from Lopes and Medina (2007) and not be applied to drainages that have carbonate rocks and basalt, which likely have different runoff characteristics.

Equation 3 seems to overestimate ungaged runoff for certain drainages in the Wassuk Range. Estimates for Cottonwood, Cat, and Corey Creeks were from 4 to 22 times more than estimates based on gaged discharge (table 5). Ungaged runoff estimated for Squaw Creek (300 acre-ft/yr) compared fairly well to the estimate based on gaged data (420 acre-ft/yr). Rose Creek was used in the regression, so a comparison of ungaged and gaged runoff would not be valid. Cottonwood, Cat, and Corey Creeks have large areas with relatively gentle slopes in the drainage area, which seem to decrease runoff. Little Squaw Creek and Powell Canyon also have large areas with gentle slopes. Ungaged runoff for these drainages was assumed to be overestimated by four times, which is the low end of the comparison to gaged basins, so estimates were reduced 75 percent.

\section{Correction to Evapotranspiration Rates}

During the computation of water budgets, it became apparent that ET rates reported by Allander and others (2009) were too high. The open-water evaporation rate of $5.0 \mathrm{ft} / \mathrm{yr}$ for Walker Lake estimated a larger volume of outflow than could be accounted for by the estimated inflow and storage change. The Walker River and precipitation account for 92 percent of all inflow and are known with a high level of certainty. Storage change also is known to a high level of certainty so the imbalance in the water budget had to be due to the evaporation rate. Water budgets for the rest of the Walker River basin also had too much outflow using land-based ET rates.

A different approach of estimating open-water evaporation was possible because inflow from the Walker River was negligible during a recent, unprecedented drought.
The drought began in 1987 when annual streamflow at the Wabuska gage was about 50 percent of the 1971-2000 streamflow normal of 138,000 acre-ft. Annual streamflow at the Wabuska gage from 1988-94 was 18,400-31,400 acre-ft, which was 13-23 percent of the 1971-2000 streamflow normal. When annual streamflow at the Wabuska gage is less than 35,000 acre-ft, diversions, ET, and infiltration reduce flow to less than 1,000 acre-ft/yr at the Lateral 2-A gage. This small amount of streamflow is lost to stream infiltration and ET before reaching Walker Lake.

When inflow from the Walker River is negligible, the evaporation rate $(E)$ is simply the annual decline in lake altitude $\left(\Delta_{L A}\right)$ plus the annual precipitation rate $\left(I_{p p t}\right)$ and subsurface-discharge rate $\left(I_{s b s f c}\right)$ :

$$
E=\Delta_{L A}+I_{p p t}+I_{s b s f c}
$$

Equation 4 is analogous to a pan-evaporation measurement but without the need for a correcting coefficient. Lake altitude has been measured monthly to the nearest $0.01 \mathrm{ft}$ since 1928 so $\Delta_{L A}$ is known accurately. $I_{p p t}$ during 2005 and 2006 were within $0.7 \mathrm{in} / \mathrm{yr}$ of precipitation rates at Hawthorne, Nev., so $I_{p p t}$ also is known accurately. Independent estimates of subsurface discharge range from 8,500 to 23,400 acre-ft/yr (Lopes and Allander, 2009), but the lower value is consistent with other water-budget estimates (this report). $I_{s b s f c}$ was estimated by dividing 8,500 acre-ft/yr, which was assumed to be constant, by the annual mean lake surface area.

$E$ ranged from 4.1 to $4.7 \mathrm{ft} / \mathrm{yr}$ during 1988-94 (table 7). The average of $4.3 \mathrm{ft} / \mathrm{yr}$ is 14 percent less than the $5.0 \mathrm{ft} / \mathrm{yr}$ of evaporation calculated by Allander and others (2009). A total of 34,000 acre-ft/yr of subsurface discharge would be needed for the two estimates to be equal, which is 40 percent more than the maximum estimate. No errors were found in computations of ET data. The error could be because the Bowen ratio method used to measure lake evaporation assumes closure in the energy budget. However, energy budgets typically do not close and have residuals of about 10 to 30 percent (Foken, 2008).

Harding (1965) and Milne (1987) estimated evaporation less subsurface inflow as a residual of a water budget. Assuming constant discharge, subsurface inflow would add about $0.2 \mathrm{ft} / \mathrm{yr}$ to their estimate based on the mean lake surface area from 1928 to 1986 . Harding's (1965) evaporation rate corrected for subsurface inflow is $4.3 \mathrm{ft} / \mathrm{yr}$ and Milne's (1987) is $4.6 \mathrm{ft} / \mathrm{yr}$. These rates are consistent with the $4.3 \mathrm{ft} / \mathrm{yr}$ estimated from equation 4, so an evaporation rate of $4.3 \mathrm{ft} / \mathrm{yr}$ was used for Walker Lake in this report. Land-based ET rates also were reduced by 14 percent. 
Table 6. Estimated streamflow normals from ungaged drainages in the Walker River basin, California and Nevada, 1971-2000.

[Drainage numbers are shown in figure 14. Equation 3 was used to make estimates unless noted otherwise. Abbreviations: LCL, lower 95th-percentile confidence limit; Normal, 1971-2000 average annual runoff; UCL, upper 95th-percentile confidence limit; acre-ft/yr, acre-foot per year; $\mathrm{mi}^{2}$, square mile; -, not estimated]

\begin{tabular}{|c|c|c|c|c|c|}
\hline $\begin{array}{c}\text { Drainage } \\
\text { No. }\end{array}$ & Drainage & $\begin{array}{c}\text { Drainage } \\
\text { area }\left(\mathrm{mi}^{2}\right)\end{array}$ & $\begin{array}{c}\text { LCL } \\
\text { (acre-ft/yr) }\end{array}$ & $\begin{array}{c}\text { Normal } \\
\text { (acre-ft/yr) }\end{array}$ & $\begin{array}{c}\text { UCL } \\
\text { (acre-ft/yr) }\end{array}$ \\
\hline \multicolumn{6}{|c|}{ Antelope Valley } \\
\hline 20 & Nevada Creek & 1.1 & 0 & 10 & 100 \\
\hline 21 & California Creek & 1.4 & 0 & 20 & 120 \\
\hline 22 & Slinkard Creek & 30.1 & 2,600 & 3,900 & 5,100 \\
\hline \multirow[t]{2}{*}{23} & Mill Creek & 22.8 & 5,400 & 6,000 & 6,600 \\
\hline & Subtotal (rounded) & & 8,000 & 10,000 & 12,000 \\
\hline \multicolumn{6}{|c|}{ Sweetwater Range } \\
\hline 24 & Unnamed \#1 & 1.3 & 90 & 140 & 180 \\
\hline 25 & Unnamed \#2 & .8 & 0 & 20 & 70 \\
\hline 26 & Sweetwater Creek & 8.0 & 2,400 & 3,000 & 3,600 \\
\hline 27 & Quaking Aspen Creek & .8 & 100 & 120 & 150 \\
\hline 28 & Cottonwood Creek & .6 & 110 & 130 & 150 \\
\hline 29 & Silverado Creek & 1.7 & 470 & 540 & 620 \\
\hline 30 & Ferris Creek & 4.5 & 1,300 & 1,800 & 2,200 \\
\hline 31 & Green Creek & 1.6 & 320 & 360 & 400 \\
\hline \multirow[t]{2}{*}{32} & Fryingpan Creek & 11.5 & 2,300 & 2,600 & 3,000 \\
\hline & Subtotal (rounded) & & 7,000 & 9,000 & 10,000 \\
\hline \multicolumn{6}{|c|}{ Bridgeport Valley } \\
\hline 33 & By-Day Creek & 4.2 & 600 & 700 & 800 \\
\hline \multirow[t]{2}{*}{34} & Log Cabin Creek & 1.6 & 0 & 0 & 100 \\
\hline & Subtotal (rounded) & & 600 & 700 & 900 \\
\hline \multicolumn{6}{|c|}{ East Wassuk Range north of Walker Lake } \\
\hline 35 & Reese River Canyon & 12.8 & 0 & 180 & 490 \\
\hline \multirow[t]{2}{*}{36} & Deadman Canyon & 3.1 & 170 & 220 & 280 \\
\hline & Subtotal (rounded) & & 200 & 400 & 800 \\
\hline \multicolumn{6}{|c|}{ East Wassuk Range adjacent to Walker Lake } \\
\hline 37 & Unnamed creek south of Deadman & 6.0 & 310 & 430 & 540 \\
\hline 38 & Copper Canyon & 4.7 & 0 & 60 & 180 \\
\hline 39 & Dry Creek & 11.7 & 0 & 100 & 400 \\
\hline \multirow[t]{2}{*}{40} & Dutch Creek & 4.6 & 590 & 670 & 750 \\
\hline & Subtotal (rounded) & & 900 & 1,300 & 1,900 \\
\hline \multicolumn{6}{|c|}{ East Wassuk Range south of Walker Lake } \\
\hline 41 & House Creek & 2.4 & 260 & 300 & 340 \\
\hline 42 & Little Squaw Creek & 12.2 & 1,200 & ${ }^{1} 350$ & 1,600 \\
\hline 43 & North Canyon Creek & 6.6 & 380 & 510 & 640 \\
\hline 44 & Alum Creek & 6.2 & 260 & 390 & 520 \\
\hline 45 & Willow Creek & 3.4 & 10 & 100 & 180 \\
\hline 46 & Cottonwood Creek (south) & 7.0 & 520 & 650 & 780 \\
\hline 47 & Johnston Creek & 3.6 & 390 & 450 & 510 \\
\hline \multirow[t]{2}{*}{48} & Powell Canyon & 16.4 & 2,400 & ${ }^{1} 650$ & 2,900 \\
\hline & Subtotal (rounded) & & - & 3,400 & - \\
\hline
\end{tabular}

${ }^{1}$ Original estimate reduced by 75 percent. 
Table 7. Estimated evaporation from Walker Lake, Nevada, during the 1987-94 drought.

[Groundwater discharge is assumed to be constant at 8,500 acre-feet during each year, and streamflow at Walker River near Wabuska, Nevada (10301500), was less than 23 percent of the 1971-2000 average and assumed to be lost before reaching the lake]

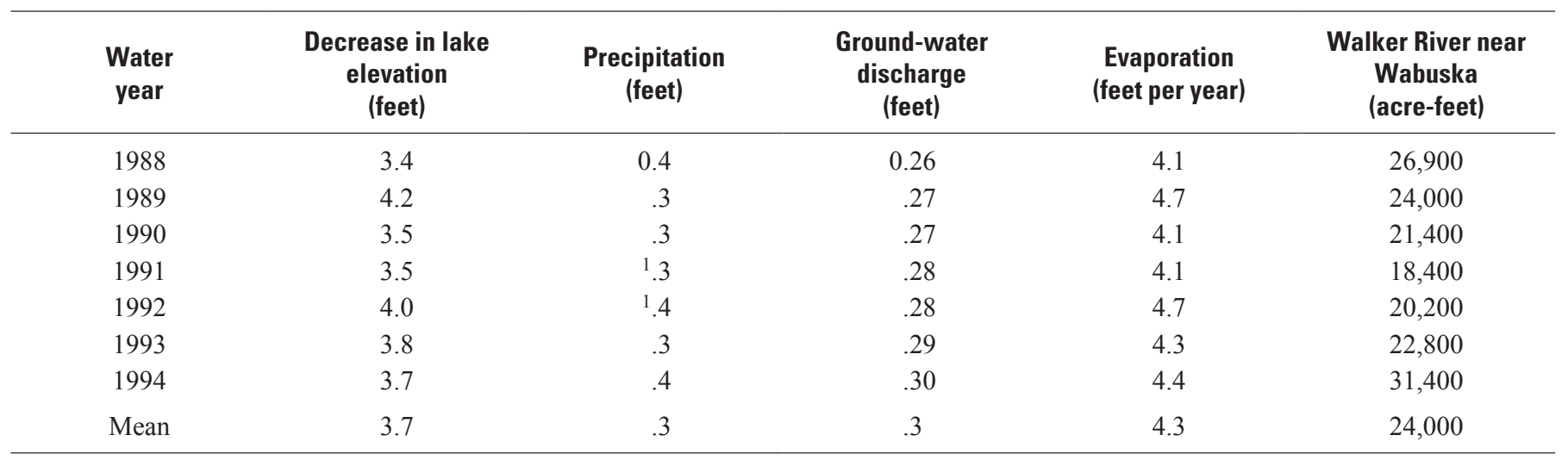

${ }^{1}$ Precipitation data from Mina, Nevada, used due to incomplete data at Hawthorne, Nevada.

\section{Upper Walker River Basin Surface-Water Budgets}

The Walker River basin upstream from the Wabuska gage has alluvial valleys separated by mountains comprised of consolidated rock with low hydraulic conductivity. The alluvial aquifer in each valley thins or pinches out at the downstream end, forcing most groundwater to discharge into the river. Streamflow is gaged where the river enters and exits the valleys. Subsurface flow between valleys is a small percentage of the streamflow. Estimating groundwater recharge, pumpage, and storage change in each valley is beyond the scope of this study, but the gaged streamflow makes estimating the surface-water budget within each valley an easy task.

Total surface-water inflow to the upper Walker River basin was estimated to be 387,000 acre-ft/yr (rounded to the nearest 1,000 acre-ft/yr) This is 60,000 acre-ft/yr (18 percent) more than estimated by Thomas (1995; table 8). The larger estimate partly is because Thomas (1995) did not estimate ungaged runoff or precipitation on Topaz Lake and Bridgeport Reservoir. About 223,000 acre-ft/yr (58 percent) is from the West Fork of the Walker River; 145,000 acre-ft/yr (37 percent) is from the East Fork of the Walker River; 17,000 acre-ft/yr (4 percent) is from the Sweetwater Range; and 2,000 acre-ft/yr (less than 1 percent) is from the Bodie Mountains, Pine Grove Hills, and western Wassuk Range. Outflow from the upper Walker River basin is 138,000 acre-ft/yr at the Wabuska gage. About 249,000 acre-ft/yr (64 percent) of inflow is diverted for irrigation, transpired by riparian vegetation, evaporates from reservoirs, and recharges alluvial aquifers.

\section{Antelope Valley}

Streamflow entering Antelope Valley prior to diversions is gaged at West Walker River near Coleville, Calif. (Coleville gage, 10296500), which has a 1971-2000 streamflow normal of 211,000 acre-ft/yr (fig. 13 and table 8). Ungaged runoff is about 10,000 acre-ft/yr and total stream inflow is 221,000 acre-ft/yr (tables 8 and 9).

Topaz Lake is at an altitude of 5,000 ft in the Carson precipitation zone (table 2) and receives about $0.8 \mathrm{ft} / \mathrm{yr}$ of precipitation. Reservoir storage has been measured daily at Topaz Lake since 1922. The 1971-2000 mean daily releasable storage volume is 28,500 acre- $\mathrm{ft}$, which corresponds to a surface area of 1,900 acres (Rush and Hill, 1972). Direct precipitation on Topaz Lake is about 2,000 acre-ft/yr and total surface-water inflow to Antelope Valley is 223,000 acre-ft/yr.

Outflow from Antelope Valley, gaged at West Walker River at Hoye Bridge near Wellington (Hoye Bridge gage, 10297500), is 193,000 acre-ft/yr (fig. 13 and table 9). Total stream loss in Antelope Valley is about 30,000 acre-ft/yr (13 percent). Most stream loss is due to agricultural diversions and evaporation from Topaz Lake.

Topaz Lake is about 1,000 ft higher than Walker Lake so evaporation must be less than the $4.3 \mathrm{ft} / \mathrm{yr}$ at Walker Lake. Myrup and others (1979) used the energy-balance method to estimate $3.6 \mathrm{ft} / \mathrm{yr}$ of evaporation from Lake Tahoe $(6,225 \mathrm{ft})$. This estimate compares well with Vorster (1985) who used pan-evaporation data and an evaporation-altitude relation to estimate a freshwater-evaporation rate of $3.8 \mathrm{ft} / \mathrm{yr}$ at Mono Lake $(6,370 \mathrm{ft})$. Assuming a linear relation in the Walker, Mono, and Tahoe Basins, evaporation $(E)$ decreases $0.3 \mathrm{ft} / \mathrm{yr}$ per 1,000-ft increase in altitude from Walker Lake $\left(\Delta_{\text {Altitude }}\right)$ :

$$
E=4.3-\Delta_{\text {Altitude }} * 0.3
$$


This rate compares well to Harding (1965), who estimated evaporation decreases about $0.4 \mathrm{ft} / \mathrm{yr}$ per 1,000 - $\mathrm{ft}$ increase in altitude. Using equation 5, an altitude difference of 1,000 ft, and an average surface area of 1,900 acres, the evaporation rate is $4.0 \mathrm{ft} / \mathrm{yr}$ and about $8,000 \mathrm{acre}-\mathrm{ft} / \mathrm{yr}$ of stream loss is evaporation from Topaz Lake.

The remaining 22,000 acre-ft/yr of stream loss is due mostly to diversions. During 2000, a total of 7,700 acres were irrigated in Antelope Valley. Mapping of circular fields indicated 500 acres were irrigated by wells and center pivots. Groundwater is pumped to flood irrigate fields in Smith and Mason Valleys (Lopes and Allander, 2009), but the 2006 and 2007 pumpage inventories for Antelope Valley ${ }^{1}$ do not indicate groundwater is used for flood irrigation. The diversion rate is about 3.0 acre-ft/acre (22,000 acre-ft/7,200 acres). Antelope Valley receives about $0.8 \mathrm{ft} / \mathrm{yr}$ of precipitation so the total applied-water rate is about $3.8 \mathrm{ft} / \mathrm{yr}$. Corrected ET rates for two alfalfa fields in Mason Valley were $2.8 \mathrm{ft} / \mathrm{yr}$ and $3.5 \mathrm{ft} / \mathrm{yr}$ with an average of $3.2 \mathrm{ft} / \mathrm{yr}$ (Allander and others, 2009), so about $0.6 \mathrm{ft} / \mathrm{yr}$ (15 percent) flushes salts from the soil.

\footnotetext{
${ }^{1}$ http://images.water.nv.gov/images/Pumpage\%20Inventories/default.aspx
}

Uncorrected ET rates average $3.8 \mathrm{ft} / \mathrm{yr}$. Fields need more water than the ET rate to flush salts from the soil, so the corrected ET rate compares well to the applied-water rate of $3.8 \mathrm{ft} / \mathrm{yr}$ but the uncorrected ET rate is too high. Some of the difference between total applied-water and corrected ET rates could be due to riparian ET and infiltration along the river, but these losses likely are minimal.

\section{Smith Valley}

Streamflow into Smith Valley is 201,000 acre-ft/yr and is the sum of 193,000 acre-ft/yr at the Hoye Bridge gage and 8,000 acre-ft/yr from Desert Creek near Wellington, Nev. (Desert Creek gage, 10299100; fig. 13 and tables 8 and 9). Most ungaged runoff from the Pine Nut Range drains toward Artesia Lake and was assumed to contribute negligible flow. Outflow from Smith Valley, measured at West Walker River near Hudson (Hudson gage, 10300000), is 147,000 acre-ft/yr (fig. 13 and table 9). Total stream loss in Smith Valley is about 54,000 acre-ft/yr (27 percent).

Table 8. Summary of surface-water inflows in the upper Walker River basin, California and Nevada.

[Abbreviations: LCL, lower 95th-percentile confidence limit; Normal, 1971-2000 average annual runoff; UCL, upper 95th-percentile confidence limit; USGS, U.S. Geological Survey; acre-ft/yr, acre-foot per year; -, does not apply]

\begin{tabular}{|c|c|c|c|c|}
\hline Drainage & $\begin{array}{c}\text { USGS } \\
\text { station No. }\end{array}$ & $\begin{array}{c}\text { LCL } \\
\text { (acre-ft/yr) }\end{array}$ & $\begin{array}{c}\text { Normal } \\
\text { (acre-ft/yr) }\end{array}$ & $\begin{array}{c}\text { UCL } \\
\text { (acre-ft/yr) }\end{array}$ \\
\hline \multicolumn{5}{|c|}{ West Fork of the Walker River } \\
\hline West Walker River near Coleville, Calif. & 10296500 & 174,000 & 211,000 & 248,000 \\
\hline Ungaged runoff & - & 8,000 & 10,000 & 12,000 \\
\hline Precipitation on Topaz Lake & - & 2,000 & 2,000 & 2,000 \\
\hline Subtotal & - & 184,000 & 223,000 & 262,000 \\
\hline \multicolumn{5}{|c|}{ East Fork of the Walker River } \\
\hline Virginia Creek near Bridgeport, Calif. & 10289000 & 12,000 & 13,000 & 14,000 \\
\hline Green Creek near Bridgeport, Calif. & 10289500 & 22,000 & 22,000 & 23,000 \\
\hline Summers Creek near Bridgeport, Calif. & 10290000 & 3,900 & 4,400 & 5,000 \\
\hline Robinson Creek near Twin Lakes, Calif. & 10290500 & 45,000 & 46,000 & 47,000 \\
\hline Buckeye Creek near Bridgeport, Calif. & 10291500 & 45,000 & 46,000 & 47,000 \\
\hline Swauger Creek near Bridgeport, Calif. & 10292000 & 9,000 & 10,000 & 11,000 \\
\hline Ungaged runoff & - & 600 & 700 & 800 \\
\hline Precipitation on Bridgeport Reservoir & - & 3,000 & 3,000 & 3,000 \\
\hline Subtotal (rounded) & - & 141,000 & 145,000 & 151,000 \\
\hline \multicolumn{5}{|c|}{ Sweetwater Range } \\
\hline Desert Creek near Wellington, Nev. & 10299100 & 5,000 & 8,000 & 11,000 \\
\hline Ungaged runoff & - & 7,000 & 9,000 & 10,000 \\
\hline Subtotal & - & 12,000 & 17,000 & 21,000 \\
\hline \multicolumn{5}{|c|}{ Bodie Mountains, Pine Grove Hills, and Western Wassuk Range } \\
\hline Ungaged runoff & - & 0 & ${ }^{1} 2,000$ & 4,000 \\
\hline Grand total (rounded) & - & 336,000 & 387,000 & 438,000 \\
\hline
\end{tabular}

\footnotetext{
${ }^{1}$ Assumed value with a range of 100 percent.
} 
Table 9. Summary of surface-water budgets for the upper Walker River basin, California and Nevada, 1971-2000.

[Mean annual flows in acre-feet, 1971-2000. Abbreviations: TSTE, too small to estimate; -, does not apply]

\begin{tabular}{|c|c|c|c|c|c|}
\hline Water-budget component & Antelope Valley & Smith Valley & $\begin{array}{l}\text { Bridgeport } \\
\text { Valley }\end{array}$ & $\begin{array}{c}\text { East Fork } \\
\text { Walker River }\end{array}$ & Mason Valley \\
\hline \multicolumn{6}{|c|}{ Surface-water inflow } \\
\hline Stream inflow & 221,000 & 201,000 & 142,000 & 131,000 & 269,000 \\
\hline Open-water precipitation & 2,000 & - & 3,000 & - & - \\
\hline Total surface-water inflow & 223,000 & 201,000 & 145,000 & 131,000 & 269,000 \\
\hline Open-water evaporation & 8,000 & - & 9,000 & - & - \\
\hline Diversions & 22,000 & 54,000 & 17,000 & 6,000 & 117,000 \\
\hline Stream infiltration and riparian evapotranspiration & TSTE & TSTE & TSTE & 3,000 & 14,000 \\
\hline Stream outflow & 193,000 & 147,000 & 119,000 & 122,000 & 138,000 \\
\hline
\end{tabular}

During 2000, a total of 18,900 acres were irrigated in Smith Valley. Mapping of circular fields indicated 933 acres were irrigated by wells and center pivots. The diversion rate in Smith Valley is about $3.0 \mathrm{ft} / \mathrm{yr}(54,000$ acre-ft/17,967 acres). Lopes and Allander (2009) estimated 6,000 acre-ft/yr of groundwater is pumped to flood irrigate fields in Smith Valley, so about $0.3 \mathrm{ft}(6,000$ acre-ft/17,967 acres) of groundwater also is applied. Smith Valley is at an altitude of about $4,800 \mathrm{ft}$ in the Walker precipitation zone (table 2) and receives about $0.5 \mathrm{ft} / \mathrm{yr}$ of precipitation. The total applied-water rate of $3.8 \mathrm{ft} / \mathrm{yr}$ is the same as the rate estimated for Antelope Valley. This rate compares well to Rush (1976) who measured a total applied-water rate of $3.5 \mathrm{ft}$ in Smith Valley during the 1973 growing season. Precipitation during the nongrowing season was not included in Rush's estimate. The same applied-water rate in Antelope and Smith Valleys and the gaining river through Smith Valley (Lopes and Allander, 2009) indicate riparian ET and infiltration along the river are minimal.

\section{Bridgeport Valley}

Streamflow entering Bridgeport Valley has been gaged at 6 creeks with a total streamflow normal of 141,400 acre-ft/yr (table 8). Ungaged runoff from By-Day Creek was estimated to be $700 \mathrm{acre}-\mathrm{ft} / \mathrm{yr}$ for a total of 142,000 acre-ft/yr (tables 8 and 9). Negligible ungaged runoff was estimated for Log Cabin Creek just south of By-Day Creek.

Bridgeport Valley is at an altitude of about $6,400 \mathrm{ft}$ in the Carson precipitation zone (table 2) and receives about $1.3 \mathrm{ft} / \mathrm{yr}$ of precipitation. The storage volume of Bridgeport Reservoir has been measured daily since April 1971. Because the first 3 months of the 1971 water year are missing, the 1972-2000 mean annual storage volume of 22,800 acre-ft was assumed to be the 1971-2000 normal. Altitude/surface-area/ storage volume relations do not exist for Bridgeport Reservoir so surface area was estimated from a National Agricultural Imagery Program 1-meter resolution digital orthophotograph. On September 20, 2006, storage in Bridgeport Reservoir was 20,220 acre-ft and the surface area was about 2,500 acres. Direct precipitation on Bridgeport Reservoir is about 3,000 acre-ft/yr and total surface-water inflow to Bridgeport Valley is 145,000 acre-ft/yr (table 9).

Outflow from Bridgeport Valley, measured at East Walker River near Bridgeport, Calif. (below Bridgeport gage, 10293000), is 119,000 acre-ft/yr (fig. 13 and table 9). Total stream loss in Bridgeport Valley is 26,000 acre-ft/yr (18 percent). Most stream loss is due to agricultural diversions and evaporation from Bridgeport Reservoir. Using equation 5 and an altitude difference of $2,400 \mathrm{ft}$, the evaporation rate at Bridgeport Reservoir is $3.6 \mathrm{ft} / \mathrm{yr}$. About 9,000 acre- $\mathrm{ft} / \mathrm{yr}$ of the $26,000 \mathrm{acre}-\mathrm{ft} / \mathrm{yr}$ of stream loss is evaporation from Bridgeport Reservoir.

The remaining 17,000 acre-ft/yr of stream loss in Bridgeport Valley is due to diversions. During 2000, there were 15,900 acres of pasture grass for a diversion rate of $1.1 \mathrm{ft}$ $(17,000$ acre-ft/15,900 acres). Bridgeport Valley receives about $1.3 \mathrm{ft} / \mathrm{yr}$ of precipitation so the applied-water rate is about $2.4 \mathrm{ft} / \mathrm{yr}$. The California Department of Water Resources and USGS databases indicate no irrigation wells in the valley so this likely is the total applied-water rate. The rate of $2.4 \mathrm{ft} / \mathrm{yr}$ is less than the $2.8-4.4 \mathrm{ft} / \mathrm{yr}$ of total ET from floodirrigated pasture in Carson Valley (Maurer and others, 2006). Many fields in Bridgeport Valley have standing water, and low stream banks indicate a thin unsaturated zone and the water table is $2-3 \mathrm{ft}$ below land surface. Some water transpired by pasture grass could be shallow groundwater. 


\section{East Fork of the Walker River}

Streamflow into the East Fork of the Walker River, measured at the below Bridgeport gage, is $119,000 \mathrm{acre}-\mathrm{ft} / \mathrm{yr}$ (fig.13 and table 9). Streamflow is 129,000 acre-ft/yr at the East Walker River below Sweetwater Creek, Nev. (below Sweetwater gage, 10293050). The additional 10,000 acre-ft/yr between these gages is nearly equal to the $9,000 \mathrm{acre}-\mathrm{ft} / \mathrm{yr}$ of ungaged runoff from the Sweetwater Range (table 6). However, ungaged runoff should be more than 10,000 acre- $\mathrm{ft} / \mathrm{yr}$ because of diversion for 1,400 acres of agriculture along Sweetwater Creek. Assuming a diversion rate of $3.0 \mathrm{ft} / \mathrm{yr}$, an addition 4,000 acre- $\mathrm{ft} / \mathrm{yr}$ of ungaged runoff could flow from the Sweetwater Creek drainage, which includes all ungaged drainages in the Sweetwater Range except Fryingpan Creek. Estimated streamflow in tables 8 and $\underline{9}$ do not include this possible $4,000 \mathrm{acre}-\mathrm{ft} / \mathrm{yr}$ of ungaged runoff.

Rough Creek drains a large part of the Bodie Mountains but estimated ungaged runoff was unreasonably high, which likely is because of the large area with gentle slopes in the drainage. The estimate of 27,300 acre- $\mathrm{ft} / \mathrm{yr}$ is equivalent to a daily average discharge of $38 \mathrm{ft}^{3} / \mathrm{s}$. Discharge measurements along Rough Creek ranged from 1.86 to $3.5 \mathrm{ft}^{3} / \mathrm{s}$ during October and November 1952 (Glancy, 1971). Discharge at the below Bridgeport gage during 1952 was 60 percent more than the 1971-2000 streamflow normal, so these measurements could be higher than typical for this time of the year. It was assumed that total runoff from the Bodie Mountains, Pine Grove Hills, and the west side of the Wassuk Range is 2,000 acre-ft/yr, which is a daily average discharge of $3 \mathrm{ft}^{3} / \mathrm{s}$. Total streamflow along the East Fork of the Walker River is $131,000 \mathrm{acre}-\mathrm{ft} / \mathrm{yr}$.

Outflow, measured at East Walker River above Strosnider Ditch near Mason, Nev. (Strosnider gage, 10293500), is $122,000 \mathrm{acre}-\mathrm{ft} / \mathrm{yr}$. Stream loss along the East Fork of the Walker River is about 9,000 acre-ft/yr (7 percent). During 2000, there were 2,100 acres of irrigated land along the East Fork of the Walker River below Sweetwater Creek for a diversion rate of $4.3 \mathrm{ft} / \mathrm{yr}$ (9,000 acre-ft/2,100 acres). The East Fork of the Walker River is at an altitude of about $5,000 \mathrm{ft}$ in the Walker precipitation zone (table 2 ) and receives about $0.5 \mathrm{ft} / \mathrm{yr}$ of precipitation, so the total applied-water rate is about $4.8 \mathrm{ft} / \mathrm{yr}$, which is $1.0 \mathrm{ft}$ more than rates for Antelope and Smith Valleys.

The total applied-water rate likely is high because all loses were attributed to agricultural diversions. However, cottonwood trees grow along the river banks and the East Fork of the Walker River could be a losing reach. Assuming the diversion rate is the same as for Antelope and Smith Valleys ( $3.0 \mathrm{ft} / \mathrm{yr}$ ), about 6,000 acre-ft/yr is diverted. The remaining 3,000 acre-ft/yr is assumed to be lost to riparian ET, infiltration, or both.

\section{Mason Valley}

Streamflow into Mason Valley is 269,000 acre-ft/yr and is the sum of streamflow at the Hudson and Strosnider gages (fig. 13 and table 9). Ungaged streamflow from hills surrounding Mason Valley was assumed to be negligible. Outflow from Mason Valley, measured at the Wabuska gage, is $138,000 \mathrm{acre}-\mathrm{ft} / \mathrm{yr}$. Total stream loss in Mason Valley is $131,000 \mathrm{acre}-\mathrm{ft} / \mathrm{yr}$ (49 percent).

During 2000, there were 39,100 acres of irrigated land in Mason Valley. Mapping of circular fields indicated 136 acres were irrigated by wells and center pivots. The diversion rate in Mason Valley is about $3.4 \mathrm{ft} / \mathrm{yr}$ (131,000 acre-ft/38,964 acres). Lopes and Allander (2009) estimated 40,000 acre-ft/yr of groundwater is pumped to flood irrigate fields in Mason Valley, so about $1.0 \mathrm{ft}$ (40,000 acre-ft/38,964 acres) of groundwater also is applied. Pumpage has caused groundwater levels to decline as much as $60 \mathrm{ft}$ in Mason Valley, indicating aquifer storage is being depleted (Lopes and Allander, 2009). Mason Valley is at an altitude of about 4,400 ft in the Walker precipitation zone and receives about $0.4 \mathrm{ft} / \mathrm{yr}$ of precipitation. The total applied-water rate of $4.8 \mathrm{ft} / \mathrm{yr}$ is $1.0 \mathrm{ft} / \mathrm{yr}$ more than rates estimated for Antelope and Smith Valleys.

The total applied-water rate likely is high because all loses were attributed to agricultural diversions. However, cottonwood trees grow along the river banks and much of fhe Walker River is losing through Mason Valley (Lopes and Allander, 2009). Assuming the diversion rate is the same as for Antelope and Smith Valleys (3.0 ft/yr), About $117,000 \mathrm{acre}-\mathrm{ft} / \mathrm{yr}$ is diverted and 14,000 acre-ft/yr of riparian ET, infiltration, or both.

\section{Lower Walker River Basin Water Budgets}

Water budgets were calculated for two reaches of the lower Walker River basin between the Wabuska gage and Walker Lake. The Walker River at Lateral 2-A Siphon near Schurz, Nev. (Lateral 2-A gage, 10302002), is the last continuous gage on the Walker River and separates the Wabuska-Schurz reach from the Schurz-Lake reach. Overall and groundwater budgets were calculated for each of these reaches and an overall water budget was calculated for the combined reaches. An overall water budget was calculated for the Walker Lake area.

Figure 16 is a schematic showing the water budget components for the Wabuska-Schurz reach, Schurz-Lake reach, and Walker Lake. The Walker River is the main source of inflow. Subsurface inflow, recharge, runoff, and precipitation are small sources of inflow compared to the Walker River. As water flows down the river, losses occur from ET, diversions, stream infiltration, and pumpage. 


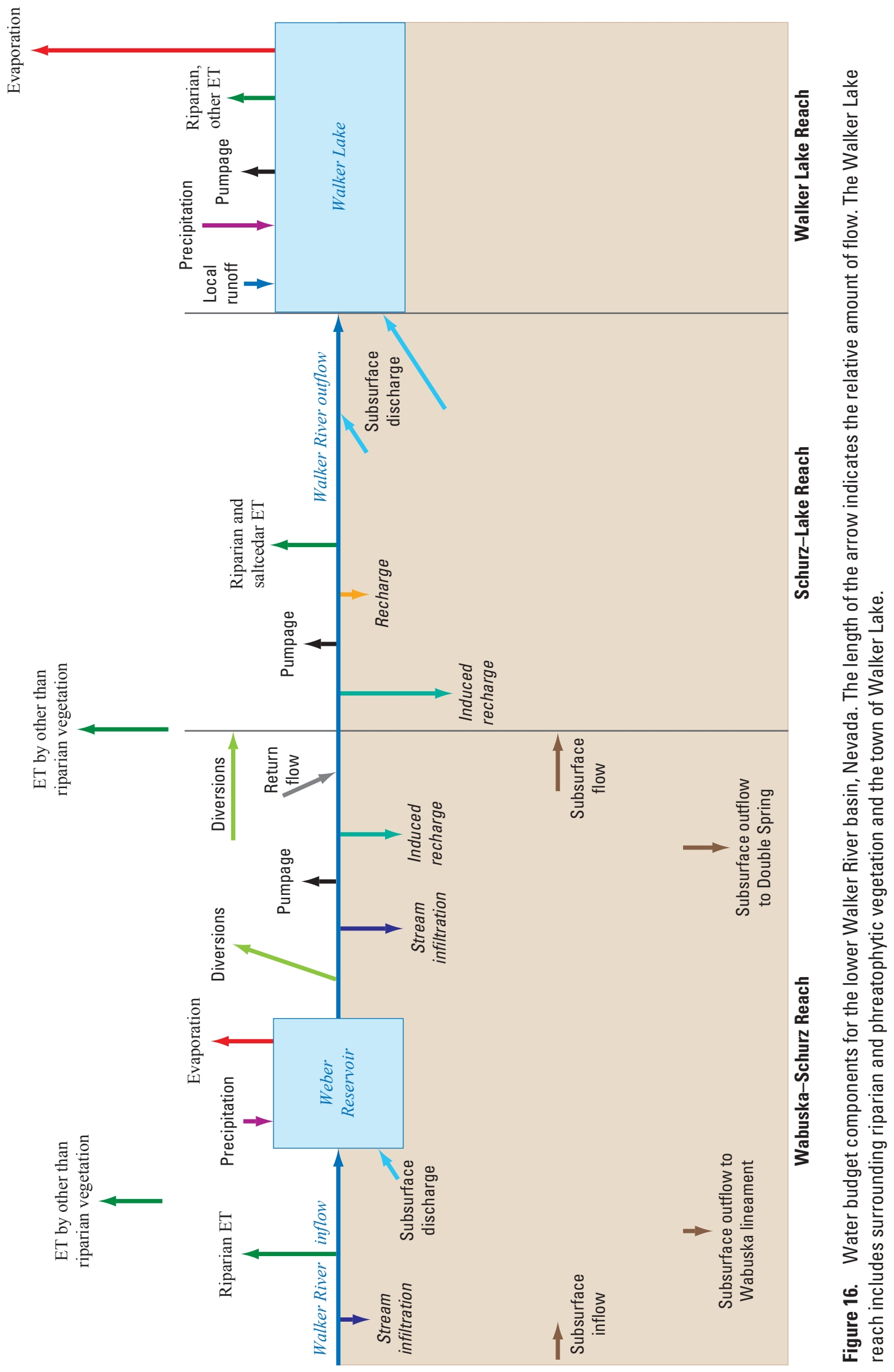


Diversions not used in the Wabuska-Schurz reach is inflow to the Schurz-Lake reach. Diversions in excess of agricultural ET either return to the river or become induced recharge, which is irrigation water that infiltrates to the water table. Riparian ET lowers groundwater levels along the river and causes streamflow to infiltrate, as indicated by seasonal variations in low-flow discharge (Lopes and Allander, 2009). Induced recharge and stream infiltration is lost to ET by riparian and phreatophytic vegetation, pumpage, subsurface outflow from the basin, and subsurface discharge to the river and Walker Lake. Evaporation from Walker Lake is the largest source of outflow.

\section{Wabuska to Schurz Reach}

\section{Overall Water Budget}

Streamflow into the Wabuska-Schurz reach at the Wabuska gage is 138,000 acre- $\mathrm{ft} / \mathrm{yr}$ (table 10). Ungaged runoff from the northern Wassuk Range and Desert Mountains was assumed to be negligible.

Table 10. Overall water budget for the Wabuska-Schurz reach, lower Walker River basin, Nevada.

[Percent is of total inflow or outflow, imbalance is percent of total inflow. Abbreviations: acre-ft/yr, acre-foot per year; $<$, less than]

\begin{tabular}{|c|c|c|}
\hline Water-budget component & $\begin{array}{c}\text { Flow } \\
\text { (acre-ft/yr) }\end{array}$ & Percent \\
\hline \multicolumn{3}{|l|}{ Inflow } \\
\hline Walker River at Wabuska & 138,000 & 99 \\
\hline Weber Reservoir precipitation & 200 & $<1$ \\
\hline Subsurface inflow & 800 & $<1$ \\
\hline Total inflow (rounded) & 139,000 & 100 \\
\hline \multicolumn{3}{|l|}{ Outflow } \\
\hline Walker River at Lateral 2-A & 108,000 & 74 \\
\hline Weber Reservoir evaporation & 2,200 & 1 \\
\hline $\begin{array}{l}\text { Riparian and phreatophytic } \\
\text { evapotranspiration }\end{array}$ & 12,500 & 9 \\
\hline Agricultural evapotranspiration & 2,300 & 2 \\
\hline Net diversions ${ }^{1}$ & 14,400 & 10 \\
\hline Pumpage & 200 & $<1$ \\
\hline Subsurface outflow to Double Spring & 2,700 & 2 \\
\hline Subsurface outflow to Schurz-Lake reach & 2,700 & 2 \\
\hline Subsurface outflow to Wabuska lineament & 100 & $<1$ \\
\hline Total outflow (rounded) & 145,000 & 100 \\
\hline Imbalance & $-6,000$ & -4 \\
\hline
\end{tabular}

\footnotetext{
${ }^{1}$ Total diversions minus estimated return flow.
}

Weber Reservoir is at an altitude of $4,200 \mathrm{ft}$ in the Walker precipitation zone (table 2) and receives about $0.4 \mathrm{ft} / \mathrm{yr}$ of precipitation. Reservoir altitude and storage only have been monitored daily since 1995. The 1971-2000 mean annual water-surface area was estimated by comparing the annual mean reservoir storage during 1996-2006 to the annual mean streamflow at the Wabuska gage and reservoir storage of Bridgeport Reservoir and Topaz Lake. The strongest Pearson correlation was between storage of Weber $\left(S_{W}\right)$ and Bridgeport Reservoirs $\left(S_{B}\right)$. Linear regression resulted in an adjusted $R^{2}$ of 0.77 :

$$
S_{W}=0.2013 * S_{B}-523 .
$$

Using equation 6 and the mean annual storage of 22,800 acre-ft for Bridgeport Reservoir, the 1971-2000 mean annual storage of Weber Reservoir is about 4,100 acre-ft. This volume corresponds to a surface area of 530 acres (Katzer and Harmsen, 1973). Inflow from precipitation is about $200 \mathrm{acre}-\mathrm{ft} / \mathrm{yr}$ and total surface-water inflow is 138,200 acre-ft/yr.

Subsurface inflow through Walker and Parker Gaps (fig. 17) was estimated by Huxel and Harris (1969). Since this estimate, wells drilled in Walker Gap indicate that alluvial sediments are only $50 \mathrm{ft}$ thick and that the average hydraulic conductivity of fluvial sediments along the Walker River is about $70 \mathrm{ft} / \mathrm{d}$ (Lopes and Allander, 2009). The transmissivity in the Walker Gap area is about 3,500 compared to $20,000 \mathrm{ft}^{2} / \mathrm{d}$ estimated by Huxel and Harris (1969), and subsurface inflow is about 100 compared to 700 acre-ft/yr (table 11).

Alluvial sediments likely are shallow in narrow gaps between bedrock outcrops like Walker and Parker Gaps. Parker Gap is about 50 percent wider than Walker Gap and was assumed to have sediments five times thicker $(250 \mathrm{ft})$ with a hydraulic conductivity of $10 \mathrm{ft} / \mathrm{d}$, the average conductivity of sediments away from the river (Lopes and Allander, 2009). The transmissivity in the Parker Gap area is about $2,500 \mathrm{ft}^{2} / \mathrm{d}$ compared to $6,700 \mathrm{ft}^{2} / \mathrm{d}$ estimated by Huxel and Harris (1969). However, the hydraulic gradient estimated from groundwater contours (Lopes and Allander, 2009) is 2.3 times steeper than estimated by Huxel and Harris (1969). The estimate of $700 \mathrm{acre}-\mathrm{ft} / \mathrm{yr}$ is the same rate estimated by Huxel and Harris (1969). Total subsurface inflow is about 800 acre-ft/yr and total inflow to the Wabuska-Schurz reach is $139,000 \mathrm{acre}-\mathrm{ft} / \mathrm{yr}$.

Outflow from the Walker River at Schurz has been measured at two gages. From 1913 to 1933, outflow was measured at the Walker River at Schurz, Nev. (Schurz gage, 10302000), which has a 1971-2000 streamflow normal of 114,000 acre-ft/yr. Since 1994, outflow has been measured at the Lateral 2-A gage, which has a streamflow normal of $108,000 \mathrm{acre}-\mathrm{ft} / \mathrm{yr}$. The locations of the Schurz and Lateral 2-A gages are within $0.6 \mathrm{mi}$ of each other and downstream from diversions and return flows on the Reservation. 


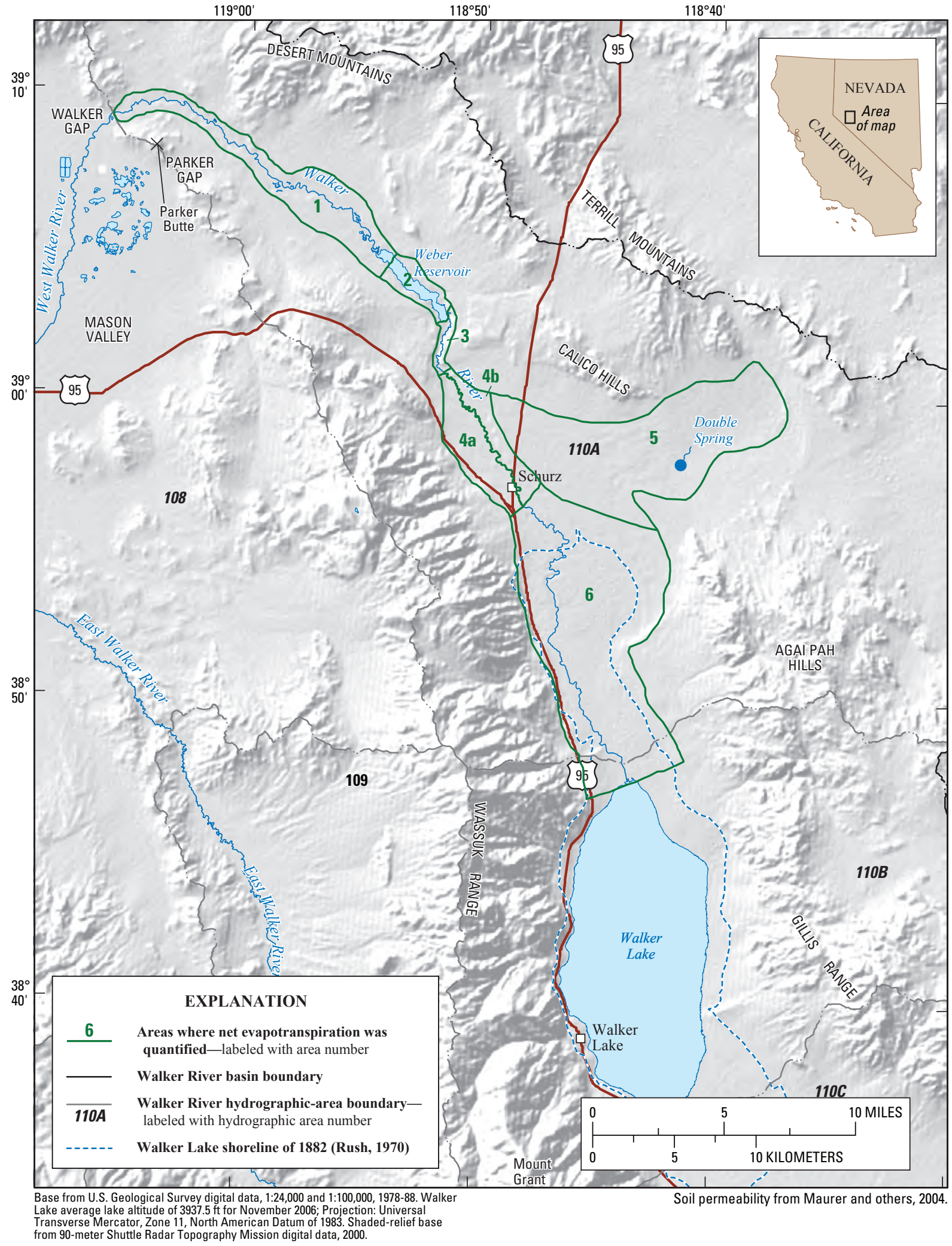

Figure 17. Selected areas of the lower Walker River basin, Nevada, where net evapotranspiration was quantified. Results are summarized in table 12. 
Table 11. Estimates of subsurface flow through Walker and Parker Gaps, lower Walker River basin, Nevada.

[Abbreviations: H\&H, values from Huxel and Harris, 1969; ft, foot; $\mathrm{ft} / \mathrm{d}$, foot per day; $\mathrm{ft}^{2} / \mathrm{d}$, foot squared per day; $\mathrm{ft} / \mathrm{mi}$, foot per mile; mi, mile; acre-ft/yr, acre foot per year; -, not determined]

\begin{tabular}{lcccccc}
\hline \multicolumn{1}{c}{$\begin{array}{c}\text { Subsurface } \\
\text { flow section }\end{array}$} & $\begin{array}{c}\text { Aquifer } \\
\text { thickness } \\
\text { (ft) }\end{array}$ & $\begin{array}{c}\text { Hydraulic } \\
\text { conductivity } \\
\text { (ft/d) }\end{array}$ & $\begin{array}{c}\text { Transmissivity } \\
\text { (ft/2/d) }\end{array}$ & $\begin{array}{c}\text { Hydraulic } \\
\text { gradient } \\
\text { (ft/mi) }\end{array}$ & $\begin{array}{c}\text { Width } \\
\text { (mi) }\end{array}$ & $\begin{array}{c}\text { Subsurface } \\
\text { inflow } \\
\text { (acre-ft//r) }\end{array}$ \\
\hline Walker Gap (this study) & 50 & 170 & 3,500 & 5 & 0.7 & 100 \\
Walker Gap (H\&H) & - & - & 20,000 & 6 & .7 & 700 \\
Parker Gap (this study) & 2250 & 110 & 2,500 & 28 & 1.1 & 700 \\
Parker Gap (H\&H) & - & - & 6,700 & 12 & 1.1 & 700 \\
Total subsurface inflow (this study) & & & & & & 800 \\
Total subsurface inflow (H\&H) & & & & & & 1,400 \\
\hline
\end{tabular}

${ }^{1}$ Average of measured values from Lopes and Allander (2009).

${ }^{2}$ Assumed value.

Annual streamflow at Schurz decreased after Weber Reservoir was constructed in 1934, especially during droughts (fig. 18B). Prior to construction of the reservoir, a minimum of 5,000 acre-ft/yr flowed past Schurz even when streamflow at the Wabuska gage was less than 20,000 acre-ft/yr (fig. 18). After construction, less than 1,000 acre-ft/yr flowed past Schurz when streamflow at the Wabuska gage was less than 35,000 acre-ft/yr. The regression equation for the Schurz gage (table 5) was used to predict annual flow at the Lateral 2-A gage for each year from 1995 through 2006 to measure the change in streamflow. Predicted flows were an average of 6,000 acre-ft/yr more than measured streamflows, which is the difference in 1971-2000 streamflow normals between the Schurz and Lateral 2-A gages. The difference also is equal to the sum of mean annual storage and evaporation from Weber Reservoir (discussed below).

The Lateral 2-A streamflow normal of 108,000 acre-ft/yr was used for Walker River outflow from the reach. Total stream loss in the Wabuska-Schurz reach is 30,200 acre-ft/yr (22 percent). Stream losses include evaporation from Weber Reservoir, diversions for irrigation, riparian ET upstream and downstream from Weber Reservoir, and stream infiltration in excess of riparian ET.

Weber Reservoir is about $200 \mathrm{ft}$ higher than Walker Lake. The evaporation rate estimated from equation 5 is $4.2 \mathrm{ft} / \mathrm{yr}$ from the mean annual surface area of 530 acres. Mean annual evaporation is about $2,200 \mathrm{acre}-\mathrm{ft} / \mathrm{yr}$.

Net ET is ET in excess of precipitation and occurs where vegetation derives water from infiltrated streamflow and groundwater. The map of ET units by Allander and others (2009) was used to estimate corrected net ET from certain areas of the lower Walker River basin (fig. 17; table 12). A total of 12,500 acre- $\mathrm{ft} / \mathrm{yr}$ of corrected net ET by riparian and phreatophytic vegetation was estimated for the WabuskaSchurz reach. Net ET was negligible for the Double Spring area east of Schurz.
Diversions on the Reservation have been gaged at the Canal No. 1 and No. 2 gages since 1995. The 1971-2000 normal diverted at the Canal No. 1 gage is 6,200 acre- $\mathrm{ft} / \mathrm{yr}$ and 11,000 acre-ft/yr at Canal No. 2 gage for a total of $17,200 \mathrm{acre}-\mathrm{ft} / \mathrm{yr}$. This value compares well to Schaefer (1980) who estimated 18,000 acre-ft was diverted during 1977.

During 2000, 3,000 acres of the Reservation were irrigated. Mapping of circular areas indicated 387 acres were irrigated by wells and center pivots in the Schurz-Lake reach. Groundwater is not used to flood irrigate fields as is done in Smith and Mason Valleys. The diversion rate on the Reservation is $6.6 \mathrm{ft} / \mathrm{yr}$ (17,200 acre-ft/2,613 acres). The Reservation is in the Walker precipitation zone and receives about $0.4 \mathrm{ft} / \mathrm{yr}$ of precipitation. The total applied-water rate is $7.0 \mathrm{ft} / \mathrm{yr}$, which is almost twice the rate in upstream valleys. Diversions in excess of net agricultural ET either return to the river or become induced recharge. The Lateral 2-A gage is downstream from return flows and measures total stream loss. Return flows were subtracted from diversions so this outflow was not accounted for twice in the water budget.

Alfalfa fields in Mason Valley are lush and have an average corrected total ET rate of $3.2 \mathrm{ft} / \mathrm{yr}$. Alfalfa fields on the Reservation are not as lush, which partly could be due to alkaline soils that were once submerged by Lake Lahontan. Canal No. 1 is used to irrigate 1,078 acres that have a corrected net ET of 1,800 acre-ft/yr. The net ET rate is $1.7 \mathrm{ft} / \mathrm{yr}(1,800 \mathrm{acre}-\mathrm{ft} / \mathrm{yr} / 1,078 \mathrm{acres})$ and the total ET rate including precipitation is $2.1 \mathrm{ft} / \mathrm{yr}$. Diversion of $6,200 \mathrm{acre}-\mathrm{ft} / \mathrm{yr}$ is in excess of net ET by about 4,400 acre-ft/yr (240 percent). Return flows were not measured so 50 percent $(2,200 \mathrm{acre}-\mathrm{ft} / \mathrm{yr})$ of the excess diversion was assumed to return to the river and 50 percent was assumed to be induced recharge. Net diversion from Canal No. 1 is 4,000 acre-ft/yr. 


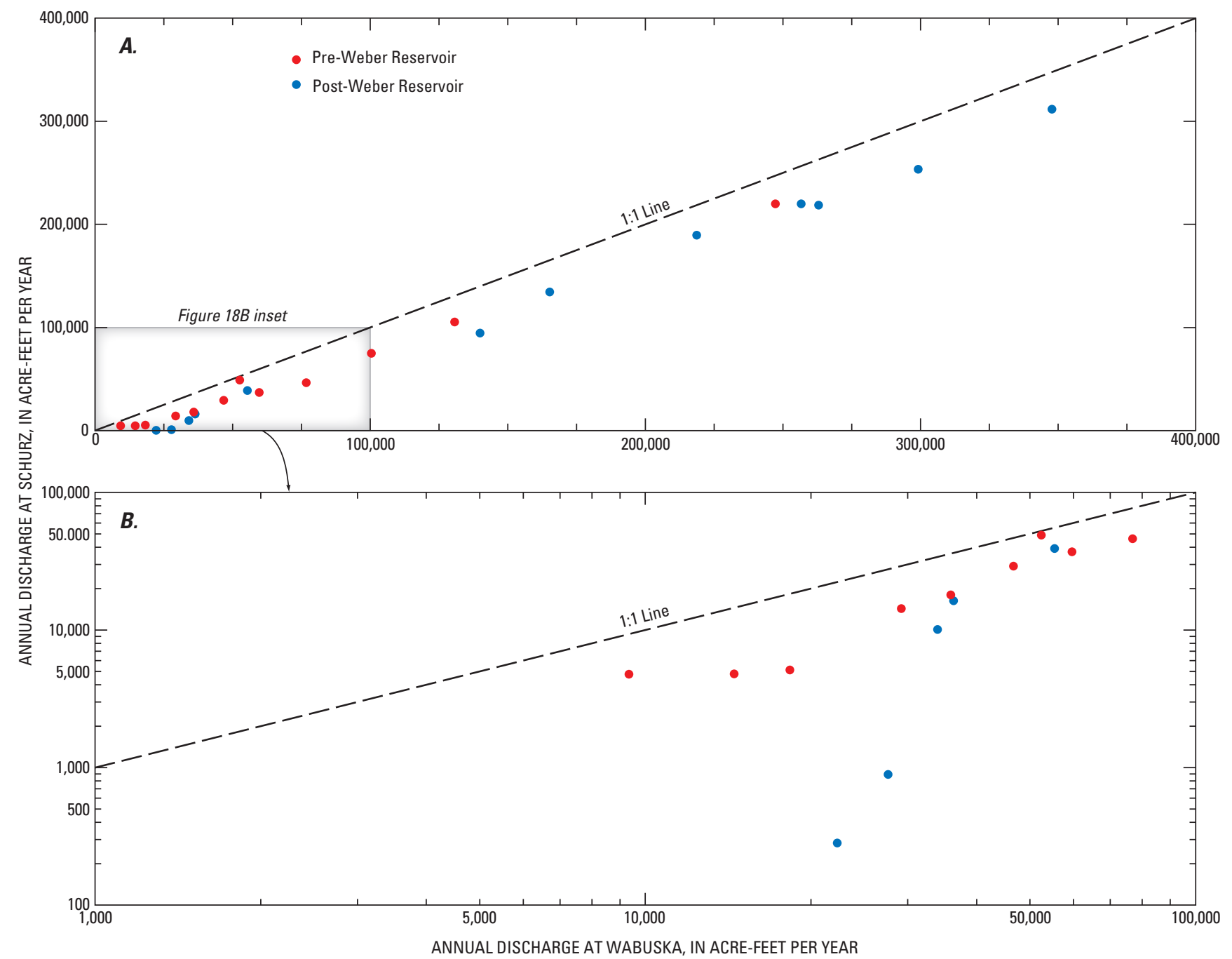

Figure 18. Annual stream discharge at Schurz, Nevada, compared to annual discharge at the Wabuska gage $(A)$ prior to and after construction of Weber Reservoir in 1934 and $(B)$ subset of data plotted on log scale to show differences at low discharge.

Canal No. 2 is used to irrigate 330 acres of alfalfa in the Wabuska-Schurz reach. Corrected net ET is 500 acre-ft/yr, the corrected net ET rate is $1.5 \mathrm{ft} / \mathrm{yr}$ (500 acre-ft/yr/330 acres), and the corrected total ET rate is $1.9 \mathrm{ft} / \mathrm{yr}$. Diversion to these fields is unknown, so the diversion rate was assumed to be the same as for Canal No. 1. Total diversion is about 1,700 acre- $\mathrm{ft} / \mathrm{yr}$, which is 240 percent $(1,200 \mathrm{acre}-\mathrm{ft} / \mathrm{yr})$ in excess of corrected net ET. Fifty percent ( 600 acre-ft/yr) of the excess diversion was assumed to be return flow and 50 percent was assumed to be induced recharge. Net diversion from Canal No. 2 is $10,400 \mathrm{acre}-\mathrm{ft} / \mathrm{yr}$ and 9,300 acre-ft/yr flows into the SchurzLake reach. Total induced recharge in the Wabuska-Schurz reach is 2,800 acre-ft/yr.

Schurz has a population of 720 , most of who live in the Wabuska-Schurz reach and use groundwater for their water supply. Schurz has no industrial and negligible commercial water use. Lopes and Evetts (2004) estimated 0.23 acre-ft/yr of pumpage per capita for domestic use. Using this rate, about $200 \mathrm{acre}-\mathrm{ft} / \mathrm{yr}$ of groundwater is pumped for domestic supply in the Schurz area.

Induced recharge and infiltration of streamflow along the Walker River has created a groundwater mound in the Schurz area that separates subsurface flow towards Walker Lake from flow towards Double Spring and out of the Walker River basin (Lopes and Allander, 2009). Lopes and Allander estimated subsurface outflow through Double Spring ranges from 1,000 to 5,000 acre-ft/yr with an average of 2,700 acre-ft/yr. In comparison, Schaefer (1980) estimated 4,500 acre-ft/yr of subsurface outflow. Subsurface flow into the Schurz-Lake reach was assumed to be the same as outflow through Double Spring. 
Table 12. Net evapotranspiration from selected areas of the lower Walker River basin, Nevada.

[Areas are shown in figure 17. Net evapotranspiration is total evapotranspiration minus precipitation. Values, in acre-feet per year, have been reduced 14 percent from estimates by Allander and others (2009)]

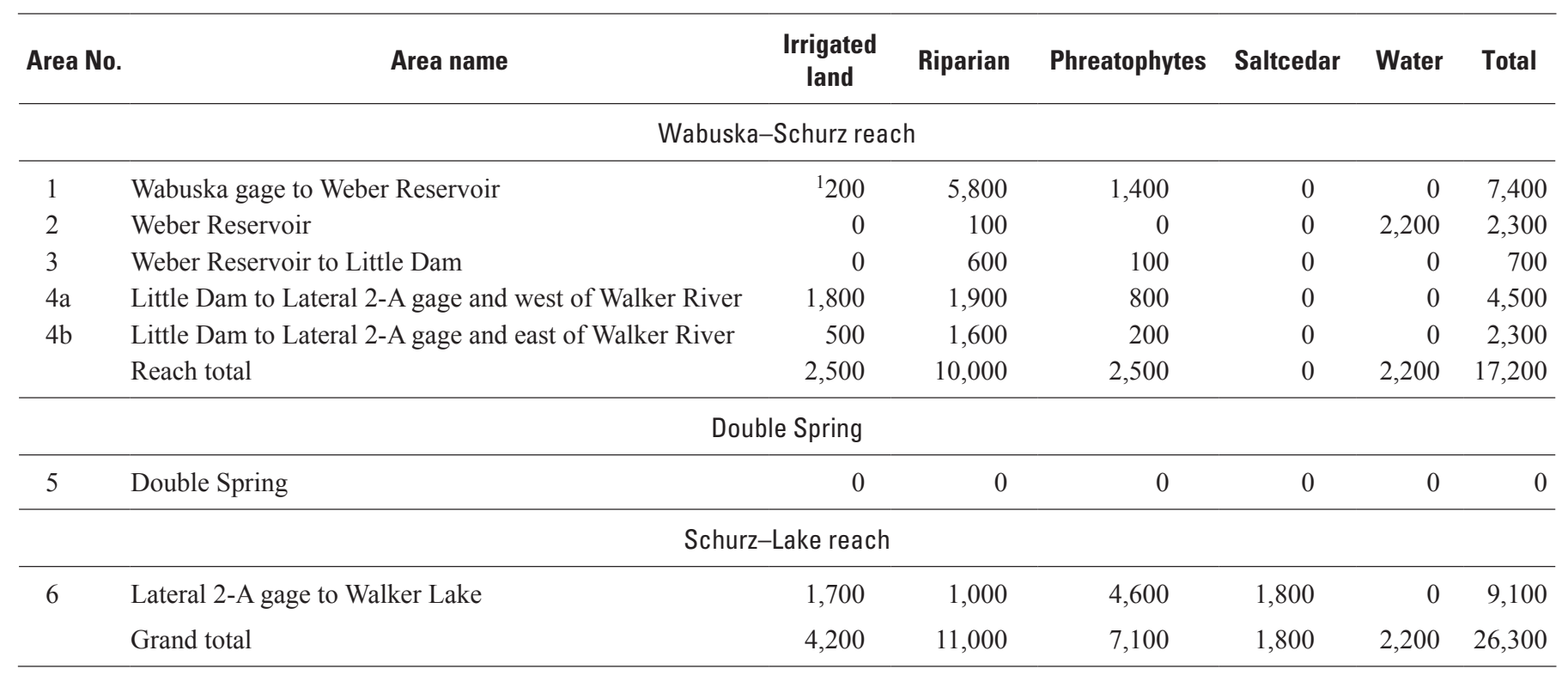

${ }^{1}$ Irrigated by streamflow from above the Wabuska gage.

Lopes and Allander (2009) hypothesized that the Wabuska lineament could be a pathway through the Desert Mountains for subsurface outflow into southern Churchill Valley. If this hypothesis is correct, then most of the outflow is from northern Mason Valley. Groundwater altitudes indicate outflow also occurs from the upper part of the Wabuska-Schurz reach. Discharge measurements indicated less than $1 \mathrm{ft}^{3} / \mathrm{s}$ of stream loss between the Wabuska and Cow Camp gages (Lopes and Allander, 2009). Infiltration in the upper part of the reach flows north towards the Wabuska lineament or flows downstream towards Weber Reservoir. Subsurface outflow through the Wabuska lineament is small and was assumed to be $100 \mathrm{acre}-\mathrm{ft} / \mathrm{yr}\left(0.14 \mathrm{ft}^{3} / \mathrm{s}\right)$. Total subsurface outflow from the Wabuska-Schurz reach is about 5,500 acre-ft/yr.

Average annual inflow to the Wabuska-Schurz reach is 139,000 acre-ft and average annual outflow is 145,000 acre-ft. The imbalance of 6,000 acre-ft/yr is 4 percent of the inflow. The small imbalance is insignificant statistically so the water budget balances. This assumes no change in groundwater storage, which is indicated by no change in water levels in the Schurz area during the past 50 years (Lopes and Allander, 2009).

\section{Groundwater Budget}

Inflow to the Wabuska-Schurz groundwater system occurs from subsurface inflow through Parker and Walker Gaps, induced recharge, and infiltration along the Walker River. Subsurface inflow was estimated to be 800 acre-ft/yr and induced recharge was estimated to be $2,800 \mathrm{acre}-\mathrm{ft} / \mathrm{yr}$ (table 13).

Stream infiltration between the Wabuska gage and Weber Reservoir was less than $1 \mathrm{ft}^{3} / \mathrm{s}$ (Lopes and Allander, 2009), so infiltration was assumed to be equal to riparian ET (table 13). Virtually all stream infiltration in excess of riparian ET occurs along the 8.5 river miles between the Little Dam and Lateral 2-A gages. Stream infiltration between the Little Dam and Lateral 2-A gages averages about 6,000 acre-ft/yr (Lopes and Allander, 2009). Corrected net ET by riparian vegetation along the Little Dam-Lateral 2-A reach is about 3,500 acre-ft/yr. Infiltration in excess of riparian ET is about 2,500 acre-ft/yr.

Groundwater outflow occurs from pumpage, subsurface outflow, and net ET. Pumpage was estimated to be $200 \mathrm{acre}-\mathrm{ft} / \mathrm{yr}$ and total subsurface outflow through the Wabuska lineament, Double Spring, and to Walker Lake was estimated to be 5,500 acre-ft/yr. Total corrected net ET by riparian and phreatophytic vegetation is 10,300 acre-ft/yr. 
Table 13. Ground-water budget for the Wabuska-Schurz reach, lower Walker River basin, Nevada.

[Percent is of total inflow or outflow, imbalance is percent of inflow. Abbreviation: acre-ft/yr, acre-foot per year]

\begin{tabular}{|c|c|c|}
\hline Water-budget component & $\begin{array}{c}\text { Flow } \\
\text { (acre-ft/yr) }\end{array}$ & Percent \\
\hline \multicolumn{3}{|l|}{ Inflow } \\
\hline Subsurface inflow & 800 & 5 \\
\hline Induced recharge & 2,800 & 18 \\
\hline $\begin{array}{l}\text { Stream infiltration Wabuksa gage-Weber } \\
\quad \text { Reservoir }^{1}\end{array}$ & 5,800 & 38 \\
\hline $\begin{array}{l}\text { Stream infiltration Little Dam-Lateral 2-A } \\
\text { gages }\end{array}$ & 6,000 & 39 \\
\hline Total inflow (rounded) & 15,000 & 100 \\
\hline \multicolumn{3}{|l|}{ Outflow } \\
\hline Pumpage & 200 & 1 \\
\hline Wabuska lineament outflow & 100 & 1 \\
\hline Subsurface outflow to Double Spring & 2,700 & 17 \\
\hline Subsurface outflow to Walker Lake & 2,700 & 17 \\
\hline $\begin{array}{l}\text { Riparian evapotranspiration Wabuksa gage-- } \\
\text { Weber Reservoir }\end{array}$ & 5,800 & 36 \\
\hline $\begin{array}{l}\text { Riparian evapotranspiration Little Dam-- } \\
\text { Lateral 2-A gages }\end{array}$ & 3,500 & 22 \\
\hline Phreatophytic evapotranspiration & 1,000 & 6 \\
\hline Total outflow (rounded) & 16,000 & 100 \\
\hline Imbalance & $-1,000$ & -7 \\
\hline
\end{tabular}

${ }^{1}$ Assumed to be equal to riparian evapotranspiration in this reach.

Total groundwater inflow was estimated to be $15,000 \mathrm{acre}-\mathrm{ft} / \mathrm{yr}$ and total outflow was estimated to be $16,000 \mathrm{acre}-\mathrm{ft} / \mathrm{yr}$. The imbalance of 1,000 acre- $\mathrm{ft} / \mathrm{yr}$ is 7 percent of the inflow. The small imbalance is insignificant statistically so the water budget balances.

\section{Schurz to Walker Lake Reach}

\section{Overall Water Budget}

Streamflow into the Schurz-Lake reach is $108,000 \mathrm{acre}-\mathrm{ft} / \mathrm{yr}$ at the Lateral 2-A gage (table 14). Ungaged runoff from the northern Wassuk Range and Gillis Range was assumed to be negligible. Diversions from Canal No. 2 that are not applied in the Wabuska-Schurz reach is inflow to the Schurz-Lake reach. About 11,000 acre- $\mathrm{ft} / \mathrm{yr}$ is diverted into Canal No. 2, 1,700 acre-ft/yr is applied to fields in the Wabuska-Schurz reach, and about 9,300 acre-ft/yr is inflow to the Schurz-Lake reach. Total surface-water inflow is 117,300 acre-ft/yr.
Table 14. Overall water budget for the Schurz-Lake reach, lower Walker River basin, Nevada.

[Percent is of total inflow or outflow, imbalance is percent of inflow. Abbreviation: acre-ft/yr; acre-foot per year. Symbol: $<$, less than]

\begin{tabular}{lrr}
\hline \multicolumn{1}{c}{$\begin{array}{c}\text { Water-budget } \\
\text { component }\end{array}$} & $\begin{array}{c}\text { Flow } \\
\text { (acre-ft/yr) }\end{array}$ & Percent \\
\hline \multicolumn{2}{c}{ Inflow } \\
Walker River at Lateral 2-A & 108,000 & 90 \\
Canal 2 diversions & 9,300 & 8 \\
Subsurface inflow & 2,700 & 2 \\
Recharge & 500 & $<1$ \\
Total inflow (rounded) & 120,000 & 100 \\
\hline & & \\
\hline Walker River at Walker Lake & 105,000 & 88 \\
Riparian evapotranspiration & 1,000 & 1 \\
Phreatophytic evapotranspiration & 4,600 & 4 \\
Saltcedar evapotranspiration & 1,800 & 2 \\
Agricultural evapotranspiration & 1,700 & 1 \\
Subsurface outflow & 5,000 & 4 \\
Total outflow (rounded) & 119,000 & 100 \\
Imbalance & 1,000 & 1 \\
\hline
\end{tabular}

Subsurface inflow to the Schurz-Lake reach was assumed to be equal to outflow at Double Spring (2,700 acre-ft/yr). Everett and Rush (1967) estimated 500 acre-ft/yr of recharge from altitudes between $6,000 \mathrm{ft}$ and 8,000 ft in HA 110A, which is the northern Wassuk Range in the Schurz-Lake reach. Total subsurface inflow is $3,200 \mathrm{acre}-\mathrm{ft} / \mathrm{yr}$. Total surface and subsurface inflow is about $120,000 \mathrm{acre-ft/yr}$.

Outflow includes streamflow and subsurface discharge into Walker Lake and net ET. Although most of the reach is gaining, stream losses occur between the Lateral 2-A gage and Walker Lake (Lopes and Allander, 2009). From 2000 to May 2005, little streamflow was measured at the Lateral 2-A gage and Walker Lake declined about $21 \mathrm{ft}$. The maximum amount of infiltration possible along this reach likely occurred during the 2005 spring runoff. Maximum infiltration was estimated to be 8,000 acre-ft/yr (Lopes and Allander, 2009).

Huffman and Carpenter, Inc. (2007), estimated 1,129 acre-ft of stream loss in the Lateral 2-A-Walker Lake reach from March 14 to September 27, 2007. Most of the loss was estimated during March and April. Monthly discharge volumes at the Lateral 2-A gage were about the same from March through May, but essentially no loss occurred during May. Aquifer storage apparently had reached a maximum even though the reach had a small amount of flow since August 2006. Almost 3,000 acre-ft/yr of net ET by saltcedar and riparian vegetation occurs along this reach (table 12), which is assumed to be the minimum stream loss except when less discharge flows into the reach. 
Streamflow into the Schurz-Lake reach has been measured only since 1995. However, annual discharge at the Wabuska gage indicates most years had sufficient discharge to maintain aquifer storage near its maximum volume (fig. 19). From 1971 to 2000, discharge less than 35,000 acre-ft/yr $\left(48 \mathrm{ft}^{3} / \mathrm{s}\right)$ flowed into the lower Walker River basin during 1977-78 and 1988-93. Low discharge also occurred during 2002-03 when less than 1,000 acre-ft/yr was measured at the Lateral 2-A gage. To estimate average stream loss in the reach during 1971-2000, it was assumed that all streamflow (1,000 acre-ft/yr) infiltrated during low discharge years, a maximum of 8,000 acre-ft/yr occurred during 1979 and 1995 following low discharge years, and 3,000 acre-ft/yr infiltrated during all other years. The average stream loss is about 3,000 acre-ft/yr (3 percent), and average streamflow reaching Walker Lake is about 105,000 acre-ft/yr.
A total of 7,400 acre-ft/yr of corrected net ET by nonagricultural vegetation occurs in the Schurz-Lake reach (table 14). Most of the ET is from phreatophytic vegetation including saltcedar. In addition, agricultural ET consumes 1,700 acre-ft/yr of Canal No. 2 diversions and groundwater pumpage. Canal No. 2 is used to flood irrigate 1,000 acres of alfalfa and wells are used to irrigate 387 acres in the Schurz-Lake reach. The corrected net ET rate is about $1.2 \mathrm{ft} / \mathrm{yr}(1,700 \mathrm{acre}-\mathrm{ft} / \mathrm{yr} / 1,387 \mathrm{acres})$ and the corrected total ET rate is $1.6 \mathrm{ft} / \mathrm{yr}$. No return flows exist to the Walker River downstream from the Lateral 2-A gage, so excess diversions become induced recharge.

Lopes and Allander (2009) used Darcy's Law and estimated subsurface outflow to Walker Lake ranges from 5,000 to 16,000 acre-ft/yr with an average of 10,000 acre-ft/yr.

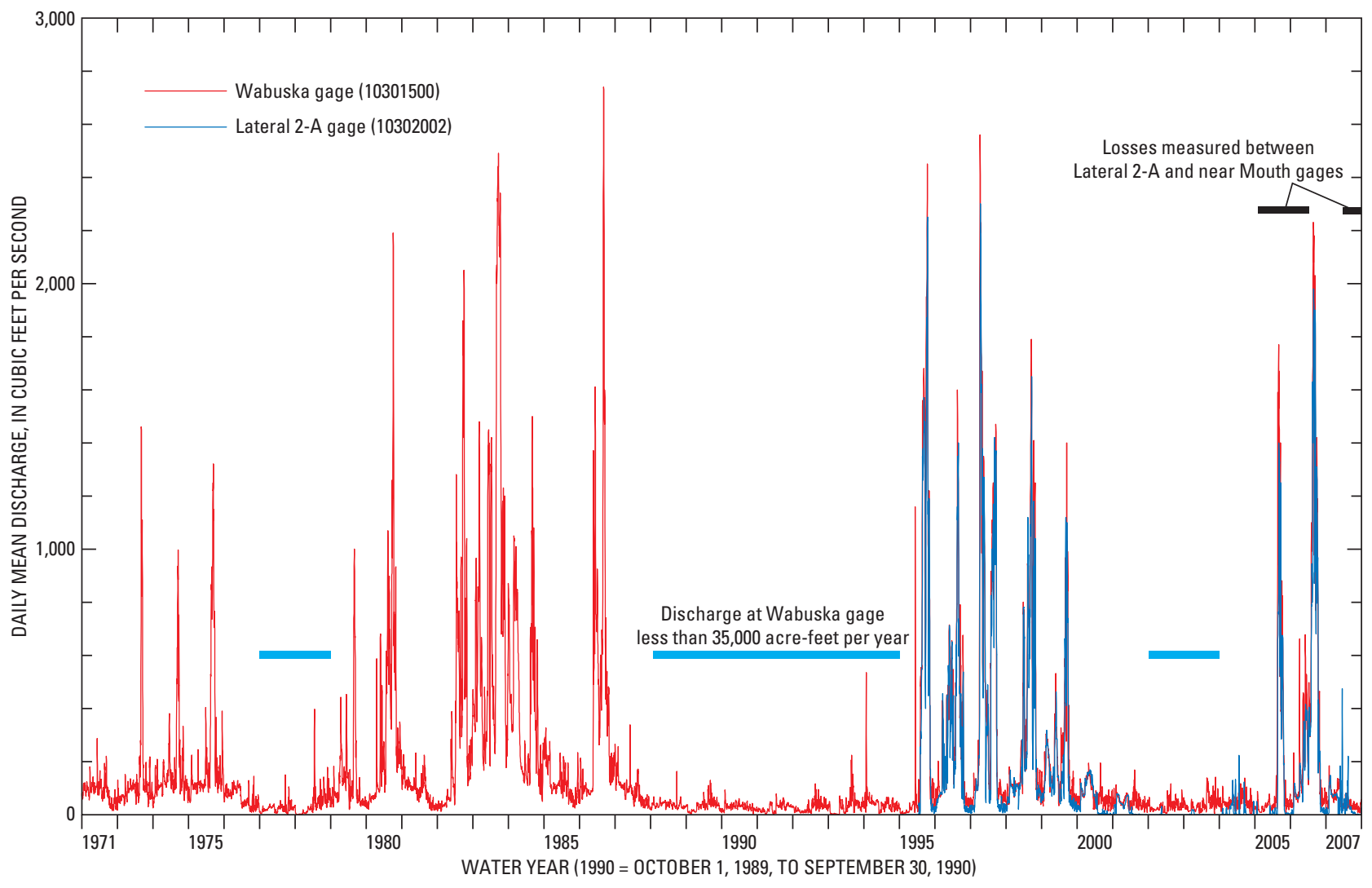

Figure 19. Discharge at streamflow gaging stations Walker River near Wabuska, Nevada (USGS station number 10301500), and Walker River at Lateral 2-A Siphon near Schurz, Nevada (10302002). Periods are indicated when discharge was low (less than 35,000 acre-ft/yr) and when losses were measured between the Lateral 2-A gage and Walker Lake. 
To check this estimate, subsurface outflow was estimated as a residual of an overall water budget for the entire reach from Wabuska to Walker Lake (table 15). Total inflow from the Walker River, subsurface inflow, and recharge is 140,000 acre-ft/yr. Total outflow from the Walker River, corrected net ET, pumpage, and subsurface outflow through Double Spring and the Wabuska lineament is $134,000 \mathrm{acre}-\mathrm{ft} / \mathrm{yr}$. The residual of 6,000 acre-ft/yr compares well to the minimum estimate of subsurface flow using Darcy's Law, so 5,000 acre-ft/yr was used in the water budget. Land-based ET rates would have to be corrected by about 30-45 percent for the residual to equal the average or maximum estimates of subsurface discharge, which is unsupported by independent estimates of lake evaporation.

Total inflow to the Schurz-Lake reach was estimated to be 120,000 acre-ft/yr and total outflow was estimated to be 119,000 acre-ft/yr. The imbalance of 1,000 acre-ft/yr is 1 percent of the inflow. The small imbalance is insignificant statistically so the water budget balances. This assumes no change in groundwater storage, which is indicated by no change in water levels during the past 50 years (Lopes and Allander, 2009).

Table 15. Overall water budget from Wabuska to Walker Lake, lower Walker River basin, Nevada.

[Percent is of total inflow or outflow, percent subsurface outflow is percent of inflow. Abbreviations: acre-ft/yr, acre-foot per year. Symbol: $<$, less than]

\begin{tabular}{|c|c|c|}
\hline $\begin{array}{l}\text { Water-budget } \\
\text { component }\end{array}$ & $\begin{array}{c}\text { Flow } \\
\text { (acre-ft/yr) }\end{array}$ & Percent \\
\hline \multicolumn{3}{|l|}{ Inflow } \\
\hline Walker River at Wabuska & 138,000 & 99 \\
\hline Subsurface inflow & 800 & $<1$ \\
\hline Weber Reservoir precipitation & 200 & $<1$ \\
\hline Recharge & 500 & $<1$ \\
\hline Total inflow (rounded) & 140,000 & 100 \\
\hline \multicolumn{3}{|l|}{ Outflow } \\
\hline Walker River at Walker Lake & 105,000 & 78 \\
\hline Pumpage & 200 & $<1$ \\
\hline Riparian evapotranspiration & 11,000 & 8 \\
\hline Phreatophytic evapotranspiration & 7,100 & 6 \\
\hline Saltcedar evapotranspiration & 1,800 & 1 \\
\hline Agricultural evapotranspiration & 4,000 & 3 \\
\hline Weber Reservoir evaporation & 2,200 & 2 \\
\hline $\begin{array}{l}\text { Subsurface outflow to Double Spring, } \\
\text { Wabuska lineament }\end{array}$ & 2,800 & 2 \\
\hline Total outflow - subsurface outflow to lake & 134,000 & 100 \\
\hline Subsurface outflow to lake (residual) & 6,000 & 4 \\
\hline
\end{tabular}

\section{Groundwater Budget}

Groundwater inflow to the Schurz-Lake reach includes subsurface inflow from the Wabuska-Schurz reach, stream infiltration, groundwater recharge, and induced recharge. Subsurface inflow was assumed to be 2,700 acre-ft/yr, stream infiltration was estimated to be 3,000 acre-ft/yr, and groundwater recharge was estimated to be 500 acre- $\mathrm{ft} / \mathrm{yr}$ (Everett and Rush, 1967; table 16). Induced recharge occurs from the 9,300 acre-ft/yr from Canal No. 2 that is applied to 1,000 acres. Excess diversions do not return to the river, so induced recharge is the inflow less 1,200 acre-ft/yr of corrected agricultural ET $(8,100$ acre-ft/yr). Total inflow to the groundwater system is $14,000 \mathrm{acre}-\mathrm{ft} / \mathrm{yr}$,

Groundwater outflow is from subsurface outflow and net ET. Subsurface outflow was estimated to be 5,000 acre-ft/yr. Pumpage was assumed to be equal to corrected net ET from 387 acres of alfalfa irrigated with groundwater. Total corrected net ET from nonagricultural vegetation is 7,400 acre-ft/yr. Total outflow from the groundwater system is $13,000 \mathrm{acre}-\mathrm{ft} / \mathrm{yr}$. The imbalance of $1,000 \mathrm{acre}-\mathrm{ft} / \mathrm{yr}$ is 7 percent of the inflow. The small imbalance is insignificant statistically so the water budget balances.

Table 16. Ground-water budget for the Schurz-Lake reach, lower Walker River basin, Nevada.

[Percent is of total inflow or outflow, percent subsurface outflow is percent of inflow. Abbreviations: acre-ft/yr, acre-foot per year]

\begin{tabular}{|c|c|c|}
\hline $\begin{array}{c}\text { Water-budget } \\
\text { component }\end{array}$ & $\begin{array}{c}\text { Flow } \\
\text { (acre-ft/yr) }\end{array}$ & Percent \\
\hline \multicolumn{3}{|c|}{ Inflow } \\
\hline Subsurface inflow & 2,700 & 19 \\
\hline Stream infiltration & 3,000 & 21 \\
\hline Recharge & 500 & 3 \\
\hline Induced recharge & 8,100 & 57 \\
\hline Total inflow (rounded) & 14,000 & 100 \\
\hline \multicolumn{3}{|c|}{ Outflow } \\
\hline Riparian evapotranspiration & 1,000 & 8 \\
\hline Saltcedar evapotranspiration & 1,800 & 14 \\
\hline Phreatophytic evapotranspiration & 4,600 & 36 \\
\hline Agricultural evapotranspiration & 500 & 4 \\
\hline Subsurface outflow & 5,000 & 38 \\
\hline Total outflow (rounded) & 13,000 & 100 \\
\hline Imbalance & 1,000 & 7 \\
\hline
\end{tabular}




\section{Walker Lake}

Surface-water inflow to Walker Lake includes 105,000 acre-ft/yr of streamflow from the Walker River (table 17). Runoff from the Gillis Range was assumed to be negligible. Drainages along the Wassuk Range that are adjacent to Walker Lake include Rose Creek at the south to an unnamed creek south of Deadman Creek at the north (tables 5 and $\underline{6}$ ). Local runoff is about 3,000 acre-ft/yr. About 2,000 acre-ft/yr is diverted to the Army Depot (Everett and Rush, 1967), so about 1,000 acre-ft/yr discharges into the lake as surface or subsurface flow.

Rose Creek Reservoir has a storage capacity of 92 acre- $\mathrm{ft}^{2}$. Cat Creek Reservoir is south of Walker Lake and has a storage capacity of 120 acre-ft, so reservoir storage is a small percentage of the runoff. A concrete catchment intercepts much of the runoff from Cottonwood Creek before it reaches the alluvial fan. The catchment runs along the base of the Wassuk Range and also intercepts runoff from Dutch, Squaw, and Rose Creeks. Excess flow from Cottonwood and Dutch Creeks is released to Walker Lake at Cottonwood Line Valve Box 14 outlet near Hawthorne, Nev. (10302170). Releases were 242 acre-ft during 2006 and 357 acre- $\mathrm{ft}$ during 2007. The average release was assumed to be $300 \mathrm{acre}-\mathrm{ft} / \mathrm{yr}$ and about $700 \mathrm{acre}-\mathrm{ft} / \mathrm{yr}$ is subsurface discharge along the west side of Walker Lake.

Walker Lake is in the Walker precipitation zone and receives about $0.4 \mathrm{ft} / \mathrm{yr}$ of precipitation. The average lake altitude during 1971-2000 was 3,959.3 ft, which corresponds to a water-surface area of 36,620 acres (Lopes and Smith, 2007). Total inflow from precipitation is $14,600 \mathrm{acre}-\mathrm{ft} / \mathrm{yr}$. Total surface-water inflow is $122,600 \mathrm{acre}-\mathrm{ft} / \mathrm{yr}$, which is 94 percent of all inflow.

Subsurface inflow from north of Walker Lake was estimated to be 5,000 acre-ft/yr (table 17). Lopes and Allander (2009) estimated subsurface inflow from south of Walker Lake ranges from 2,200 to 6,600 acre-ft/yr with an average of 4,400 acre-ft/yr. In comparison, Everett and Rush (1967) estimated subsurface inflow south of Walker Lake is 2,000 acre-ft/yr. Everett and Rush (1967) estimated 2,000 acre-ft/yr of recharge in Whisky Flat and 3,500 acre-ft/yr of recharge around Hawthorne. Total runoff from the Wassuk Range south of Walker Lake is about 3,800 acre-ft/yr, so recharge estimates likely are overestimated. About 1,600 acre-ft/yr of groundwater is pumped to irrigate 500 acres in Whisky Flat and the city of Hawthorne has municipal wells in Whisky Flat, so some recharge is intercepted before reaching Walker Lake. Pumpage in Whisky Flat has decreased groundwater levels $70 \mathrm{ft}$ since 1956 (Lopes and Allander, 2009), indicating pumpage exceeds recharge. Therefore, the minimum value of 2,200 acre-ft/yr of subsurface inflow was used in the water budget.

\footnotetext{
${ }^{2}$ http://water.nv.gov/Engineering/Dams/Dam_Query.cfm
}

Table 17. Overall water budget for Walker Lake, Nevada.

[Percent is of total inflow or outflow, storage decrease and imbalance is percent of outflow. Abbreviation: acre-ft/yr; acre-foot per year. Symbol: <, less than]

\begin{tabular}{|c|c|c|}
\hline $\begin{array}{c}\text { Water-budget } \\
\text { component }\end{array}$ & $\begin{array}{c}\text { Flow } \\
\text { (acre-ft/yr) }\end{array}$ & Percent \\
\hline \multicolumn{3}{|c|}{ Inflow } \\
\hline Walker River & 105,000 & 81 \\
\hline Local runoff ${ }^{1}$ & 3,000 & 2 \\
\hline Precipitation & 14,600 & 11 \\
\hline Subsurface inflow-north & 5,000 & 4 \\
\hline Subsurface inflow-south & 2,200 & 2 \\
\hline Subsurface inflow-east & 600 & $<1$ \\
\hline Total inflow (rounded) & 130,000 & 100 \\
\hline \multicolumn{3}{|c|}{ Outflow } \\
\hline Lake evaporation & 157,400 & 97 \\
\hline Evapotranspiration & 2,200 & 1 \\
\hline Diverted local runoff & 2,000 & 1 \\
\hline Pumpage & 100 & $<1$ \\
\hline Total outflow (rounded) & 162,000 & 100 \\
\hline \multicolumn{3}{|c|}{ Storage } \\
\hline Storage decrease & $-29,000$ & 18 \\
\hline Imbalance & $-3,000$ & 2 \\
\hline
\end{tabular}

${ }^{1} 300 \mathrm{acre}-\mathrm{ft} / \mathrm{yr}$ of local runoff is surface flow and $700 \mathrm{acre}-\mathrm{ft} / \mathrm{yr}$ is subsurface flow to the west side of Walker Lake.

The estimate of $600 \mathrm{acre}-\mathrm{ft} / \mathrm{yr}$ of recharge along the Gillis Range by Everett and Rush (1967) was used for subsurface inflow along the east side of Walker Lake. Total subsurface discharge from all sources around Walker Lake is $8,500 \mathrm{acre}-\mathrm{ft} / \mathrm{yr}$. Subsurface discharge includes regional flow through the aquifers towards Walker Lake and drainage from the aquifers induced by the decline in lake level. Stabilizing the lake level eventually will reduce aquifer drainage, but drainage likely has been only a few percent of the overall water budget. However, water managers should be aware of the transient nature of the water budget.

Virtually all outflow is evaporation from Walker Lake. The evaporation rate estimated from equation 4 is $4.3 \mathrm{ft} / \mathrm{yr}$. The 1971-2000 mean annual surface area is 36,620 acres and mean annual evaporation is about 157,400 acre-ft/yr (table 17). Corrected net ET by vegetation surrounding Walker Lake is about 2,200 acre-ft/yr and 2,000 acre-ft/yr of local runoff is diverted to the Army Depot. The town of Walker Lake has a population of 391 that uses groundwater for their water supply. Using a per capita pumpage rate of $0.23 \mathrm{acre}-\mathrm{ft} / \mathrm{yr}$ (Lopes and Evetts, 2004), about $100 \mathrm{acre-ft/yr}$ of groundwater is pumped for domestic supply. Total outflow is about 162,000 acre-ft/yr. 
Average annual storage change is the difference in the volume of Walker Lake between 1971 and 2000 divided by 30 . The beginning storage volume was 3,173,000 acre-ft and the ending storage volume was 2,299,000 acre-ft. Total storage loss was 874,000 acre-ft and the average annual loss was 29,000 acre-ft. The range is storage loss was estimated using an error of $0.5 \mathrm{ft}$ in the bathymetry of Walker Lake (Lopes and Smith, 2007). Minimum storage loss is 28,000 acre-ft/yr and maximum storage loss is $30,000 \mathrm{acre}-\mathrm{ft} / \mathrm{yr}$.

The water budget for Walker Lake is:

$$
I-O=\Delta_{s},
$$

where

$I$ is the annual total inflow to the lake;

$O$ is the annual total outflow from the lake; and

$\Delta_{s}$ is the annual change in lake storage (negative for a declining lake).

Total inflow was estimated to be 130,000 acre-ft/yr, total outflow is 162,000 acre- $\mathrm{ft} / \mathrm{yr}$, and the difference is $-32,000 \mathrm{acre}-\mathrm{ft} / \mathrm{yr}$. Storage change estimated directly is $-29,000 \mathrm{acre}-\mathrm{ft} / \mathrm{yr}$. The imbalance in the water budget is $-3,000$ acre- $\mathrm{ft} / \mathrm{yr}$, which is 2 percent of the total outflow (table 17). The small imbalance is insignificant statistically so the water budget balances.
Dissolved-solids concentrations of 8,000, 10,000, and $12,000 \mathrm{mg} / \mathrm{L}$ have been proposed to maintain a healthy population of Lahanton cutthroat trout in Walker Lake. These concentrations represent long-term average concentrations, but during prolonged droughts dissolved solids could reach concentrations that threaten the fishery. Water budgets were calculated to provide managers a range in supplemental inflows needed to maintain dissolved-solids concentrations in Walker Lake at 8,000, 10,000, and 12,000 mg/L.

Years of supplemental inflow, above average inflow, or both will be needed to raise the lake-surface altitude and dilute salts to these concentrations. Then, supplemental inflow will need to be sustained to maintain the lake-surface altitude and dissolved-solids concentrations. The relation between lake-surface altitude and dissolved-solids concentrations is nonlinear, so a polynomial regression equation was used to estimate dissolved-solids concentrations $(D S)$ at lake-surface altitudes ( Alt $_{\text {Lake }}$ ) ranging between $3,931 \mathrm{ft}$, the altitude in October 2008, and 4,000 ft:

$$
\begin{aligned}
D S=2.9872521 * 10^{7} & -14,931.8144 * A^{*} t_{\text {Lake }} \\
& +1.8664 *\left(\text { Alt }_{\text {Lake }}\right)^{2} .
\end{aligned}
$$

Equation 8 has an adjusted $R^{2}$ of 0.96 (fig. 20). Rounding regression coefficients or extrapolation of the equation outside the altitude range may lead to erroneous estimates.

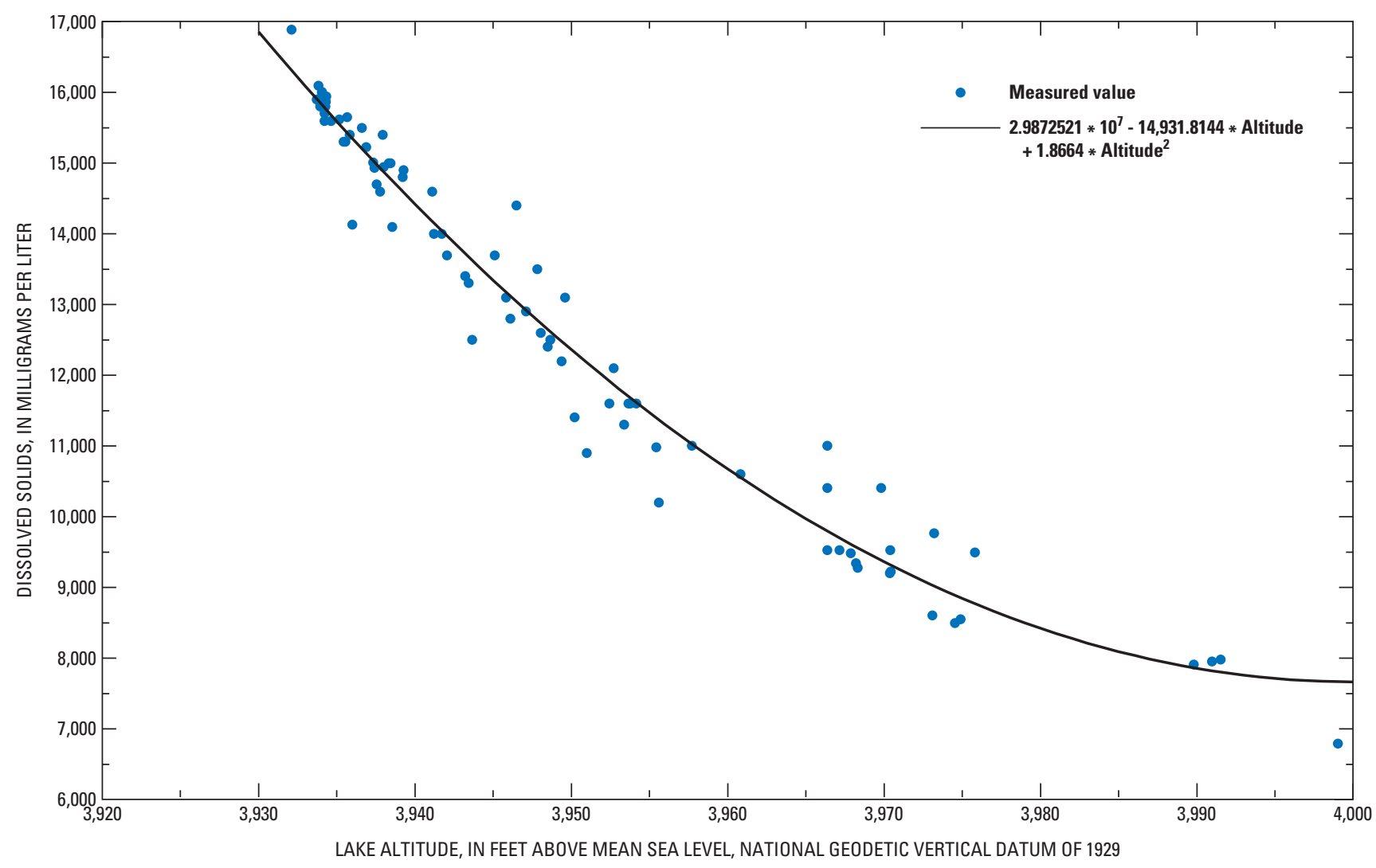

Figure 20. Dissolved-solids concentrations versus lake altitude, Walker Lake, Nevada. 
The dissolved-solids concentration is about $8,000 \mathrm{mg} / \mathrm{L}$ when the lake-surface altitude is $3,986 \mathrm{ft}, 10,000 \mathrm{mg} / \mathrm{L}$ at 3,965 $\mathrm{ft}$, and $12,000 \mathrm{mg} / \mathrm{L}$ at 3,952 ft (table 18). Thomas (1995) estimated dissolved solids would be $10,000 \mathrm{mg} / \mathrm{L}$ at 3,964 ft, which compares well to equation 8 . Seven-hundred thousand, 1.2 million, and 2 million acre- $\mathrm{ft}$ of additional water is needed to raise Walker Lake from 3,931 ft to 3,952, 3965, and $3,986 \mathrm{ft}$, respectively.

Water budgets were calculated assuming that increases in lake-surface altitude only affect the amount of precipitation and evaporation. However, groundwater inflow and phreatophytic discharge could decrease as surrounding areas become submerged. Supplemental inflows range from 26,000 to 53,000 acre-ft/yr depending on the lake-surface altitude. At 3,964 ft, supplemental inflow is 35,000 acre- $\mathrm{ft} / \mathrm{yr}$, which is 12,000 acre-ft/yr less than estimated by Thomas (1995). The difference partly is due to Thomas (1995) estimating Walker River inflow as a residual, which combined errors from the water budget and resulted in a lower estimate of inflow from the river than this study.

Table 18. Water budget to maintain lake-surface altitudes between 3,952 and 3,986 feet at Walker Lake, Nevada.

[Altitude is feet above National Geodetic Vertical Datum of 1929. Water budgets are based on 1971-2000 average annual flows. Supplemental volume is volume needed to raise lake-surface altitude from 3,931 feet. Supplemental inflow is inflow in addition to average annual inflows needed to maintain altitude. Abbreviations: acre-ft, acre-foot; acre-ft/yr, acre-foot per year; ft; foot; $\mathrm{mg} / \mathrm{L}$, milligram per liter]

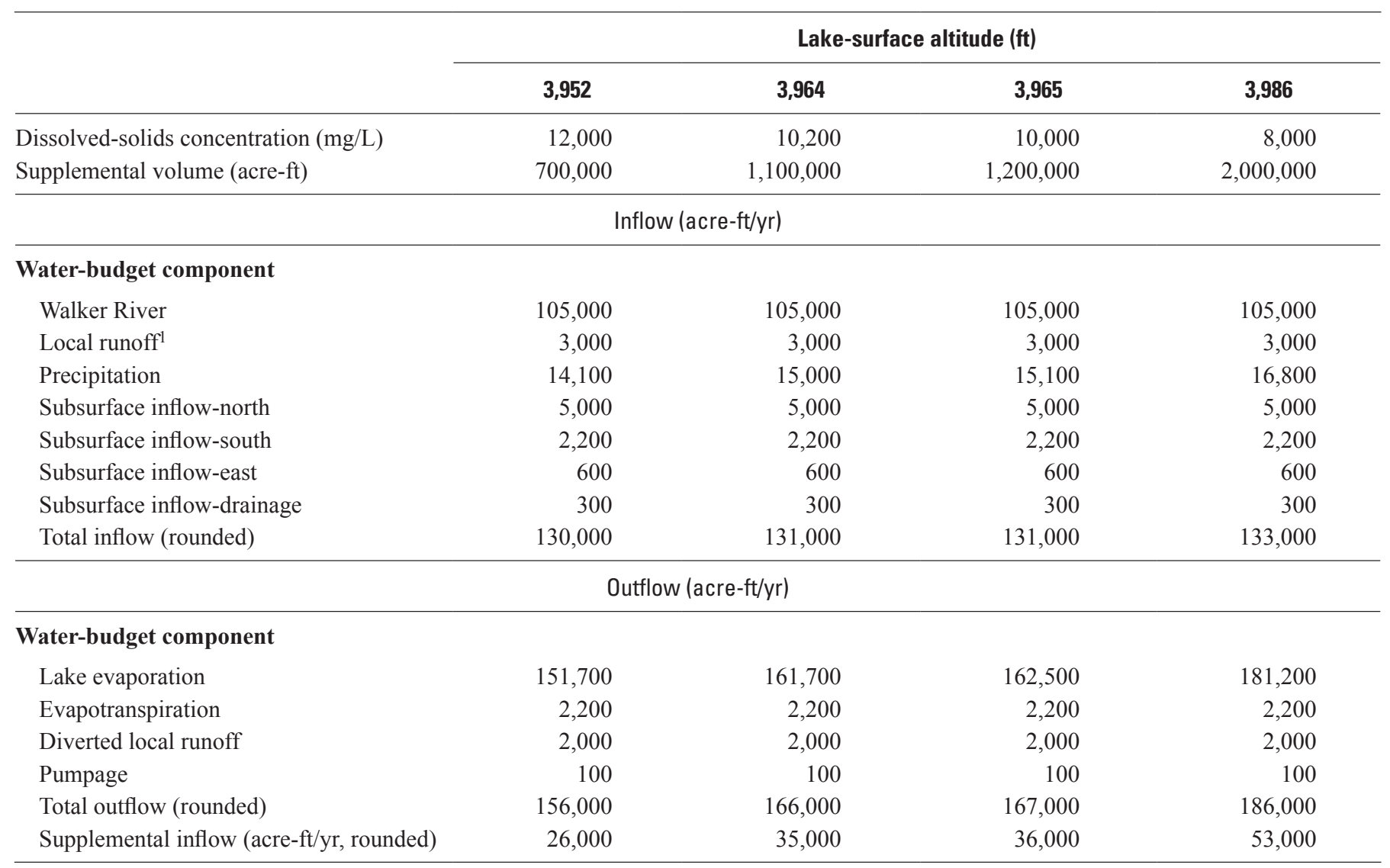

\footnotetext{
${ }^{1} 300$ acre-ft/yr of local runoff is surface flow and 700 acre-ft/yr is subsurface flow to the west side of Walker Lake.
} 


\section{Summary}

The Walker River is the main source of inflow to Walker Lake, a closed-basin lake in west-central Nevada. The only outflow from Walker Lake is evaporation from the lake surface. Between 1882 and 2008, agricultural diversions resulted in a lake-level decline of more than $150 \mathrm{ft}$ and storage loss of 7,400,000 acre-ft. Evaporative concentration increased dissolved solids from 2,500 to $17,000 \mathrm{mg} / \mathrm{L}$. The increase in salinity threatens the survival of the Lahontan cutthroat trout, a native species listed as threatened under the Endangered Species Act.

This report describes streamflow in the Walker River basin and an updated water budget of Walker Lake. The report emphasizes the lower Walker River basin, which is the area downstream from the Wabuska gage. Surface-water budgets in the upper Walker River basin upstream from the Wabuska gage also are described. Water budgets are based on average flows for a 30-year period (1971-2000).

The Walker River basin is about 3,950 square miles and straddles the California-Nevada border. Most streamflow in the basin originates as snowmelt in the Sierra Nevada that flows down the East and West Forks of the Walker River, which merge in southern Mason Valley. Outflow from Mason Valley and inflow to the lower Walker River basin is measured at the Wabuska gage. Three reservoirs in the basin store water that is used to irrigate fields in Smith Valley, Mason Valley, and the Reservation. In 2000, a total of 88,600 acres of irrigated land was mapped in the Walker River basin. The primary crop in the basin is alfalfa.

Walker Lake is bounded on the west by the Wassuk Range and on the east by the Gillis Range. The Wassuk Range rises abruptly from the lake by more than 7,000 ft and has a maximum altitude of 11,239 ft at Mount Grant. The Gillis Range is not as steep and has a maximum altitude of 7,887 ft. The lowest altitude is 3,849 ft at the deepest part of Walker Lake. Mean annual precipitation ranges from about 4 in. at Walker Lake to 56 in. along the crest of the Sierra Nevada. Mean precipitation at Mount Grant, the highest mountain adjacent to Walker Lake, is about $16 \mathrm{in} / \mathrm{yr}$.

Total surface-water inflow to the upper Walker River basin was estimated to be 387,000 acre-ft/yr. About 223,000 acre-ft/yr (58 percent) is from the West Fork of the Walker River; 145,000 acre-ft/yr (37 percent) is from the East Fork of the Walker River; 17,000 acre-ft/yr (4 percent) is from the Sweetwater Range; and 2,000 acre-ft/yr (less than 1 percent) is from the Bodie Mountains, Pine Grove Hills, and western Wassuk Range. Outflow from the upper Walker River basin is 138,000 acre- $\mathrm{ft} / \mathrm{yr}$ at the Wabuska gage. About 249,000 acre-ft/yr (64 percent) of inflow is diverted for irrigation, transpired by riparian vegetation, evaporates from lakes and reservoirs, and recharges alluvial aquifers.
Stream losses in Antelope, Smith, and Bridgeport Valleys are due to evaporation from reservoirs and agricultural diversions with negligible stream infiltration or riparian evapotranspiration (ET). The diversion rate in Antelope and Smith Valleys was estimated to be $3.0 \mathrm{ft} / \mathrm{yr}$ in each valley. Irrigated fields receive an additional $0.8 \mathrm{ft} / \mathrm{yr}$ of precipitation, groundwater pumpage, or both for a total applied-water rate of $3.8 \mathrm{ft} / \mathrm{yr}$. The corrected total ET rate for alfalfa is about $3.2 \mathrm{ft} / \mathrm{yr}$, so about $0.6 \mathrm{ft} / \mathrm{yr}$ (15 percent) flushes salts from the soil. The diversion rate in Bridgeport Valley was estimated to be $1.1 \mathrm{ft} / \mathrm{yr}$ and precipitation is $1.3 \mathrm{ft} / \mathrm{yr}$. The total appliedwater rate of $2.4 \mathrm{ft} / \mathrm{yr}$ is used to irrigate pasture grass.

The total applied-water rate in East Fork of the Walker River and Mason Valley was estimated to be $4.8 \mathrm{ft} / \mathrm{yr}$ in each valley. The higher rate likely is due to appreciable infiltration, riparian ET, or both. Stream loss from infiltration and riparian ET is about 3,000 acre-ft/yr along the East Fork of the Walker River and about 14,000 acre-ft/yr in Mason Valley.

Overall and groundwater budgets were calculated for the Wabuska-Schurz reach and Schurz-Lake reach. Overall water budgets were calculated for the combined reaches and Walker Lake. Imbalances in the water budgets range from 1 to 7 percent, which is insignificant statistically, so the water budgets balance. Total inflow from Wabuska to Walker Lake is 140,000 acre-ft/yr. Stream and subsurface discharge into the northern end of Walker Lake totals 110,000 acre-ft/yr. About 30,000 acre- $\mathrm{ft} / \mathrm{yr}$ is lost on the Reservation from agricultural ET, ET by native and invasive vegetation, domestic pumpage, and subsurface outflow through Double Spring and the Wabuska lineament.

Alfalfa fields in the upper Walker River basin are lush and have a corrected total ET rate of $3.2 \mathrm{ft} / \mathrm{yr}$. Alfalfa fields on the Reservation are not as lush and have a corrected total ET rate of 1.6-2.1 ft/yr, but the total applied-water rate is about $7.0 \mathrm{ft} / \mathrm{yr}$. Most excess diversions become induced recharge, which was estimated to total almost 11,000 acre-ft/yr.

Surface and subsurface inflow to Walker Lake totals 130,000 acre-ft/yr. Virtually all outflow is evaporation from the lake and totals $162,000 \mathrm{acre}-\mathrm{ft} / \mathrm{yr}$. The difference between inflow and outflow is $-32,000$ acre-ft/yr. Storage change is $-29,000$ acre- $\mathrm{ft} / \mathrm{yr}$ for an imbalance of 3,000 acre-ft/yr ( 2 percent). The small imbalance is insignificant statistically so the water budget balances.

Water budgets were calculated to provide managers a range in supplemental inflows needed to maintain dissolvedsolids concentrations at 8,000, 10,000, and 12,000 mg/L. From about 700,000 to 2,000,000 acre- $\mathrm{ft}$ is needed to dilute the lake to these concentrations and from 26,000 to 53,000 acre-ft/yr of supplemental inflow is needed to maintain concentrations at 8,000 to $12,000 \mathrm{mg} / \mathrm{L}$. Years of supplemental inflow, above average inflow, or both, will be needed to raise the lakesurface altitude and dilute salts. 


\section{Acknowledgments}

This study would not have been possible without access to lands and wells granted by numerous private land owners in the basin. The authors also appreciate the cooperation, assistance, and information provided by: Jon McMasters and Gina Wachsmuth, Walker River Paiute Tribe; Kenneth Spooner, Walker River Irrigation District; James Shaw, Walker River Federal Watermaster; John Peterson and David Musselman, Hawthorne Army Ammunition Depot; and Elmer Bull, Nevada Department of Wildlife.

\section{References Cited}

Allander, K.K., Smith, J.L., and Johnson, M.J., 2009, Evapotranspiration in the lower Walker River basin, west-central Nevada: U.S. Geological Survey Scientific Investigations Report 2009-5079, 62 p. Available at http:// pubs.usgs.gov/sir/2009/5079/

Anning, D.W., and Konieczki, A.D., 2005, Classification of hydrogeologic areas and hydrogeologic flow systems in the basin and range physiographic province, southwestern United States: U.S. Geological Survey Professional Paper 1702, 44 p. Available at http://pubs.usgs.gov/pp/2005/ pp1702/

Bonham, H.F., 1969, Geology and mineral deposits of Washoe and Storey Counties, Nevada: Nevada Bureau of Mines and Geology Bulletin 70, 140 p.

Boyle Engineering Corp., 1976, Mineral County, Nevada, Water Resources Investigation: Prepared for the State of Nevada Department of Conservation and Natural Resources, Division of Water Resources, and Mineral County.

California Division of Mines and Geology, 2000, GIS Data for the geologic map of California: California Department of Conservation, Division of Mines and Geology, CD-ROM 2000-007.

Cardinalli, J.L., Roach, L.M., Rush, F.E., and Vasey, B.J., 1968, State of Nevada hydrographic areas, scale 1:500,000, in Rush, F.E., 1968, Index of hydrographic areas in Nevada: Nevada Division of Water Resources Information Report 6, $38 \mathrm{p}$.

Daly, Christopher, Neilson, R.P., and Phillips, D.L., 1994, A statistical-topographic model for mapping climatological precipitation over mountainous terrain: Journal of Applied Meteorology, v. 33, no. 2, p. 140-158.
Everett, D.E., and Rush, F.E., 1967, A brief appraisal of the water resources of the Walker Lake area, Mineral, Lyon, and Churchill Counties, Nevada: Nevada Department of Conservation and Natural Resources, Water ResourcesReconnaissance Report 40, 44 p.

Foken, Thomas, 2008, The energy balance closure problemAn overview: Ecological Applications, v 18, no. 6, p. 1351-1367.

GeoLytics, Inc., 2001, GeoLytics Census CD 2000 Short Form Blocks: E. Brunswick, N.J.,GeoLytics, Inc., accessed March 31, 2009, at http://censuscd.com/USCensus,Census-2000Short-Form-Blocks,Products.asp

Glancy, P.A., 1971, Water-resources appraisal of Antelope Valley and East Walker area, Nevada and California: Nevada Division of Water Resources Reconnaissance Report 53, 69 p.

Hardcastle, Jeff, 2006, Nevada county population estimates July 1, 1990 to July 1, 2006, includes cities and towns: Nevada State Demographer's Office, University of Nevada, Reno, accessed October 2, 2007, at http://www.nsbdc.org/ what/data_statistics/demographer/pubs/docs/NVPopul06. pdf

Harding, S.T., 1965, Recent variations in the water supply of the Western Great Basin: University of California-Berkeley, Water Resources Center Archives, 226 p.

Helsel, D.R., and Hirsch, R.M., 1992, Statistical methods in water resources: New York, Elsevier Science Publishers, $522 \mathrm{p}$.

Horton, G.A., 1995, Walker River chronology-A chronological history of the Walker River and related water issues: Nevada River Chronology Publication Series, Nevada Division of Water Resources, Department of Conservation and Natural Resources, accessed October 5, 2007, at http://water.nv.gov/WaterPlanning/walker/ wrchrono.cfm

Houghton, J.G., Sakamoto, C.M., and Gifford, R.M., 1975, Nevada's climate and weather: Nevada Bureau of Mines and Geology Special Publication 2, 78 p.

Huffman and Carpenter, Inc., 2007, Technical findings for 2007 irrigation season flow monitoring on the lower Walker River: Reno, Nevada, Huffman and Carpenter, Inc., Wetland Regulatory and Hydrologic Consultants, 4 p., 2 attachments.

Huxel, C.J., Jr., and Harris, E.E., 1969, Water resources and development in Mason Valley, Lyon and Mineral Counties, Nevada, 1948-65: Nevada Division of Water Resources Bulletin 38, 77 p. 
Jeton, A.E., and Maurer, D.K., 2007, Precipitation and runoff simulations of the Carson Range and Pine Nut Mountains, and updated estimates of groundwater inflow and the groundwater budgets for basin-fill aquifers of Carson Valley, Douglas County, Nevada, and Alpine County, California: U.S. Geological Survey Scientific Investigations Report 2007-5205, 56 p. Available at http://pubs.usgs.gov/ $\underline{\text { sir/2007/5205/ }}$

Katzer, T.L., and Harmsen, Lynn, 1973, Bathymetric reconnaissance of Weber Reservoir, Mineral County, Nevada: Nevada Division of Water Resources Information Report 15, 1 plate.

Lopes, T.J., 2005, Science to sustain terminal lakes-The Walker River basin study: U.S. Geological Survey Fact Sheet 2005-3124, 2 p.

Lopes, T.J., and Allander, K.K., 2009, Hydrologic setting and conceptual hydrologic model of the Walker River basin, west-central Nevada: U.S. Geological Survey Scientific Investigations Report 2009-5155, 84 p. Available at http:// pubs.usgs.gov/sir/2009/5155/

Lopes, T.J., and Evetts, D.M., 2004, Groundwater pumpage and artificial recharge estimates for calendar year 2000 and average annual natural recharge and interbasin flow by hydrographic area, Nevada: U.S. Geological Survey Scientific Investigations Report 2004-5239, 81 p. Available at http://pubs.usgs.gov/sir/2004/5239/

Lopes, T.J., and Medina, R.L., 2007, Precipitation zones of west-central Nevada: Journal of the Nevada Water Resources Association, v. 4, no. 2, p. 1-19.

Lopes, T.J., and Smith, J.L., 2007, Bathymetry of Walker Lake, west-central Nevada: U.S. Geological Survey Scientific Investigations Report 2007-5012, 26 p. Available at http://pubs.usgs.gov/sir/2007/5012/

Maurer, D.K., Berger, D.L., Tumbusch, M.L., and Johnson, M.J., 2006, Rates of evapotranspiration, recharge from precipitation beneath selected areas of native vegetation, and streamflow gain and loss in Carson Valley, Douglas County, Nevada, and Alpine County, California: U.S. Geological Survey Scientific Investigations Report 2005-5288, 70 p. Available at http://pubs.usgs.gov/ $\underline{\text { sir/2005/5288/ }}$

Maurer, D.K., Lopes, T.J., Medina, R.L., and Smith, J.L., 2004a, Hydrogeology and hydrologic landscape regions of Nevada: U.S. Geological Survey Scientific Investigations Report 2004-5131, 35 p. Available at http://pubs.usgs.gov/ $\underline{\operatorname{sir} / 2004 / 5131 /}$
Maurer, D.K., Watkins, S.A., and Burrows, R.L., 2004b, Updated computations and estimates of streamflows tributary to Carson Valley, Douglas County, Nevada, and Alpine County, California, 1990-2002: U.S. Geological Survey Scientific Investigations Report 2004-5179, 29 p. Available at http://pubs.usgs.gov/sir/2004/5179/

Maxey, G.B., and Eakin, T.E., 1949, Groundwater in White River Valley, White Pine, Nye, and Lincoln Counties, Nevada: Nevada State Engineer, Water Resources Bulletin 8, 53 p.

Milne, Wendy, 1987, A comparison of reconstructed lake-level records since the mid-1800's of some Great Basin lakes: Golden, Colo., Colorado School of Mines, Master's Thesis, 207 p.

Moore, D.O., 1968, Estimating mean runoff from ungaged semiarid areas: Bulletin of the International Association of Scientific Hydrology, v. 13, p. 29-39, accessed January 5, 2009, at http://www.cig.ensmp.fr/ iahs/hsj/131/ hysj_13 01_0029.pdf

Myrup, L.O., Powell, T.M., Godden, D.A., and Goldman, C.R., 1979, Climatological estimate of the average monthly energy and water budgets of Lake Tahoe, California-Nevada: Water Resources Research, v. 15, no. 6, p. $1499-1508$.

Nichols, W.D., 2000, Regional groundwater evapotranspiration and groundwater budgets, Great Basin, Nevada: U.S. Geological Survey Professional Paper 1628, 82 p.

Pahl, Randy, 1997, Walker River Basin gaging stationsSummary of historic and estimated streamflow, reservoir \& lake level gaging station records: Nevada Water Basin Information and Chronology Series, Nevada Division of Water Planning, Department of Conservation and Natural Resources, 19 p.

Pahl, Randy, 2000a, Walker River Basin irrigation diversions - Summary of historic surface water irrigation diversions: Nevada Water Basin Information and Chronology Series, Nevada Division of Water Planning, Department of Conservation and Natural Resources, 15 p.

Pahl, Randy, 2000b, Walker River Basin surface water budget - Summary of basin surface water inflows and outflows (1926-95): Nevada Water Basin Information and Chronology Series, Nevada Division of Water Planning, Department of Conservation and Natural Resources, 32 p.

Rush, F.E., 1968, Index of hydrographic areas in Nevada: Nevada Division of Water Resources, Information Report 6, $38 \mathrm{p}$. 
Rush, F.E., 1970, Hydrologic regimen of Walker Lake, Mineral County, Nevada: U.S. Geological Survey

Hydrologic Investigations Atlas HA-415, scale 1:62,500.

Rush, F.E., 1976, Water requirement and efficiency of sprinkler irrigation of alfalfa, Smith Valley-A case history, Nevada: Nevada Division of Water Resources, Information Report 24, 10 p.

Rush, F.E., and Hill, V.R., 1972, Bathymetric reconnaissance of Topaz Lake, Nevada and California: Nevada Division of Water Resources, Information Report 12, 1 plate.

Russell, I.C., 1885, Geologic history of Lake Lahontan-A Quaternary lake in northwestern Nevada: U.S. Geological Survey Monograph 11, 288 p.
Schaefer, D.H., 1980, An appraisal of the water resources of the Walker River Indian Reservation, Nevada: U.S. Geological Survey Open-File Report 80-427, 61 p.

Stewart, J.H., 1988, Tectonics of the Walker Lane Belt, Western Great Basin, in Ernst, W.G., ed., Metamorphism and crustal evolution of the Western United States: Rubey Volume VII, Prentice Hall, p. 683-713.

Thomas, J.M., 1995, Water budget and salinity of Walker Lake, western Nevada: U.S. Geological Survey Fact Sheet FS-115-95, 4 p.

Vorster, Peter, 1985, A water balance forecast model for Mono Lake, California: Hayward, California State University, Master's Thesis, 341 p. 
Publishing support provided by the U.S. Geological Survey Publishing Network, Tacoma Publishing Service Center

For more information concerning the research in this report, contact the Director, Nevada Water Science Center

U.S. Geological Survey

2730 N. Deer Run Road

Carson City, Nevada 89701

http://nevada.usgs.gov/water/index.htm 


$$
\text { 总 }
$$

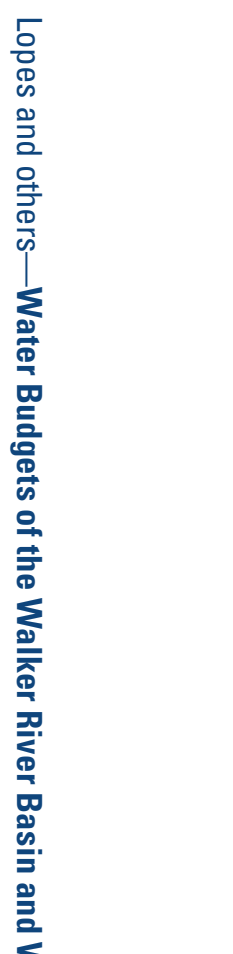

